\title{
Kernos
}

Revue internationale et pluridisciplinaire de religion grecque antique

$32 \mid 2019$

Varia

\section{Epigraphic Bulletin for Greek Religion 2016 (EBGR 2016)}

\section{Angelos Chaniotis}

\section{(2) OpenEdition \\ Journals}

Electronic version

URL: https://journals.openedition.org/kernos/3169

DOI: 10.4000/kernos.3169

ISSN: 2034-7871

\section{Publisher}

Centre international d'étude de la religion grecque antique

\section{Printed version}

Date of publication: 1 December 2019

Number of pages: $297-339$

ISBN: 978-2-87562-229-7

ISSN: 0776-3824

\section{Electronic reference}

Angelos Chaniotis, "Epigraphic Bulletin for Greek Religion 2016 (EBGR 2016)", Kernos [Online], 32 I 2019, Online since 01 October 2021, connection on 31 January 2022. URL: http:// journals.openedition.org/kernos/3169 ; DOI: https://doi.org/10.4000/kernos.3169

This text was automatically generated on 31 January 2022.

Kernos 


\title{
Epigraphic Bulletin for Greek Religion 2016 (EBGR 2016)
}

\author{
Angelos Chaniotis
}

1 The 29th issue of the EBGR presents epigraphic corpora and new epigraphic finds published in 2016 and a few contributions to the reading and interpretation of old finds. I have also summarized numerous publications of earlier years that had not been included in earlier issues of the EBGR.

2 In this issue, I summarize the content of new corpora and large epigraphic collections from Athens (98), Corinth (118), Thessaly (134), Kos (22), north Epirus and south Illyria (27), Smyrna (15), and Asia Minor (85). Among the new finds, I single out the rock-cut inscription with a cult regulation in Panoteus, previously known from a quotation in the cult regulation of the Labyadai in Delphi (107); this text, along with another rockcut inscription from the same site, still remains puzzling. I also note a new Dionysiac/ Orphic tablet from Crete (127), a new cult regulation from Larisa (133), a public document from Atrax that excludes a certain individual from the cults of a family group (134), a novel attestation of a 'new hero' (28; cf. 70), an honorific decree from Dionysopolis that praises the honorand for the orderly distribution of sacrificial meat (117), a building account from Didyma (55), a cult foundation in Nakoleia (9), an epitaph that assimilates the honors paid to the deceased woman with those paid to the immortal gods (86), and a rhetorically elaborate funerary imprecation from Neapolis in Karia (84). An inscription of Kos provides the first attestation for the participation of a Homerist in 'sacred contests' (22). In an epitaph from Atrax, a man speaks from his grave and regrets the fact that he no longer can attend sacrifices (134). There is an abundance of interesting or new epithets $(\delta \varepsilon \xi \alpha \mu \varepsilon ́ v \alpha$ for Athena: 105; $\delta \eta \mu$ í for

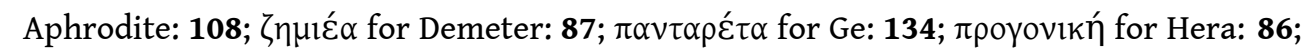

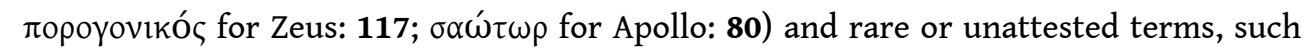

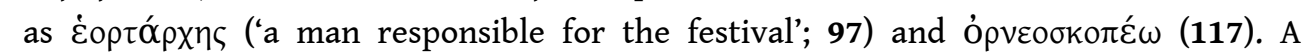
dedication to Zeus Spaloxios and Zeus Patroios by their priest in Aphrodisias shows that the two epithets distinguished between two different gods, who shared the properties of Zeus (33). As regards religious mentality, some of the graffiti in Smyrna reveal a 
belief in divine healing (15). Among the new defixiones, I single out a curse tablet that is formulated like a letter to chthonic powers (23); it may be among the earliest examples of prayers for justice (mid-4th cent.).

3 The principles explained in Kernos 4 (1991), p. 287-288, and Kernos 7 (1994), p. 287, also apply to this issue. Abbreviations that are not included in the list are those of L'Année Philologique and J.H.M. STRUBBE (ed.), Supplementum Epigraphicum Graecum. Consolidated Index for Volumes XXXVI-XLV (1986-1995), Amsterdam, 1999, as well as of later volumes of the SEG. If not otherwise specified, dates are BCE. Dr. Matthew Peebles (Columbia University) has improved the English text.

\section{Abbreviation}

\begin{tabular}{|l|l|}
\hline $\begin{array}{l}\text { Aphrodisias } \\
\text { Papers V: }\end{array}$ & $\begin{array}{l}\text { R.R. SMITH et alii (eds.), Aphrodisias Papers V. Excavations and Research at Aphrodisias, } \\
\text { 2006-2016 (Journal of Roman Archaeology, Suppl. 103), Portsmouth, 2016. }\end{array}$ \\
\hline
\end{tabular}

\section{Selected Topics}

\section{Geographical areas (in the sequence adopted by SEG)}

Attica: 119; Athens: 14. 16. 23. 28. 38. 39. 47. 71. 75. 87. 125. 142. 143; Acharnai: 6. Korinthia: Corinth: 118. 144; Isthmia: 46. Argolid: Argos: 119. Kleonaia: Nemea: 24. Epidauria: Epidauros: 77. 103. 116. Kynouria: 52. Aigina: 119. Lakonia: 20. 82; Sparta: 48. 129. 130. Arkadia: 119; Stymphalos: 115. Elis: 119; Olympia: 60. 61. Boiotia: 16; Oropos: 73; Tanagra: 119; Thebes: 119; Thespiai: 5. 119. Delphi: 107. Phokis: 50. 74. 119; Panopeus: 107. Thessaly: 119; Atrax: 134; Larisa: 131-133; Pharsalos: 139. Epirus: 27; Ambrakia: 105; Dodona: 89. 136. Illyria: 27. Macedonia: Dion: 128; Pella: 128; Thessalonike: 63. 128. Thrace: 41; Apollonia Pontike: 117; Aquae Calidae: 117; Augusta Traiana: 117. Moesia: 40. 41; Dionysopolis: 117; Kallatis: 12; Novae: 80; Tomis: 10. Dacia: 11. North Shore of the Black Sea: Gorgippia: 93; Chersonesos in Tauris: 112; Kalos Limen: 111; Olbia: 18. 23. 108; Pantikapaion: 19. 23; Phanagoreia: 138. Delos: 14. Rhodes: 13. 121. Patmos: 99. Kos: 22. 122. Thasos: 57. 126. Samothrake: 42. Euboia: Eretria: 114; Karystos: 34. Crete: Phaistos: 51; Sfakaki: 127. Sicily: Aitna: 106; Lilybaion: 26; Selinous: 69; Syracuse: 106. Italy: Oplontis: 102; Ostia: 141; Rome: 21. Pannonia: Savaria: 17. Kyrene: 35. 68. Karia: Alabanda: 8; Aphrodisias: 32. 33; Gerga Kome: 79; Halikarnassos: 66. 67. 79. 100; Iasos: 29. 85. 91. 92; Mylasa: 62. 79. 119. 135; Neapolus: 84; Nysa: 72; Pidasa: 76. Ionia: Erythrai: 83; Lampsakos: 119; Metropolis: 43. 44; Miletos: 55. 56. 123; Smyrna: 15. 79. Lydia: 1. 59; Tripolis: 45. Aiolis: Kyme: 81. Troas: Alexandria Troas: 94; Lampsakos: 119. Mysia: Kyzikos: 95. Bithynia: Bithynion: 86; Iouliopolis: 86; Kreteia: 86; Nikaia: 86. 96. 97; Prousias: 86. Pontos: Zela: 86. Paphlagonia: Gangra: 86. Galatia: 54. Phrygia: 1. 3. 11. 140; Apollonia: 58; Hierapolis: 53. Nakoleia: 9. Pisidia: 140; Tymbriada: 123. Pamphylia: Perge: 25. Lykia: Kibyra: 36. 37. 88; Korydalla: 64; Limyra: 2. 145. 146; Oinoanda: 90; Phaselis: 7; Rhodiapolis: 65; Tlos: 104. Lykaonia: 120. Kilikia: Diokaisareia: 109; Korykos: 110; Tarsos: 78. 113. 137. Phoenicia: Berytos: 4; Byblos: 147. Jordan: Gerasa: 49.

afterlife: 22. 85. 118. 134; cf. s.v. death 

(Oropos); Anakeia: 119 (Athens); Antiocheia: 104 (Antioch); Artemisia: 44 (Metropolis); Artemisia Kommodeia: 104 (Ephesos) Aspis: 104. 122 (Argos); Augusteia: 104 (Pergamon); Basileia: 98 (Lebadeia); Delia: 14; Dia 45 (Tripolis); Dionysia: 143; Eleusinia: 14; Eleutheria: 14 (Plataiai); Epinikia: 123 (Ephesos); Eusebeia: 104 (Puteoli); Hadrianeia: 104 (Athens, Anazarbos, Antioch); Halieia: 104. 119 (Rhodes); Heraia: 14. 119. 122 (Argos); Herakleia: 14 (Thebes). 104 (Tyros); Isthmia: 104. 144; Kaisarea: 144 (Corinth); Kapetolia: 121; Koina Asias: 104 (Smyrna); Koinos Agon: 104 (Syria); Kommodeia: 104 (Miletos); Kroneia: 104 (Tlos); Lykaia: 14; Maleateia: 82; Naa: 14; Nemea: 14. 104; Nemesia: 47; Nymphaia: 14 (Apollonia); Olympia: 14. 104; Olympia: 104 (Athens, Daphne); Olympia Balbilleia: 104 (Ephesos); Panathenaia: 14. 104. 125; Periporphyros: 104 (Sidon); Poseidonia: 119 (Sounion); Pythia: 14. 104; Rhomaia: 14 (Chalkis); Sebasta: 104. 121 (Neapolis). 144 (Corinth); Soteria: 14 (Delphi); Traianeia: 104 (Pergamon); Trophonia: 14 (Lebadeia)

agonistic festival: 27. 121; endowed: 65; foundation of: 43; participation of Homerists: 22

altar: 55. 72. 85. 86. 91. 94. 96. 97. 117; numbered a.: 116

amulet: 63.128

association: 25. 27. 28; cult a.: 4. 22. 81. 86. 134.138.140. 145

asylia: 62

banquet: 4.77 .83

birthday: 5

burial: 22 ; public: 32

cave, cult: 139

chorus: 4

Christianity: 118; use of pagan imagery and vocabulary: 118

confession inscription: 59

contest, funerary 119; in honor of war dead: 119; see also s.v. agonistic festival

crown: 49

cult, family: 134; exclusion from: 134

cult personnel: agonothetes 22. 43. 79. 100. 123; archiereia of the imperial cult in Asia 25; in Lykia: 104; in Prousias: 86; archiereus 25. 100. 123; archiprophetes 104; asiarches 25; heortarches 97; hiereia 27. 44. 79. 98. 100. 134. 146; hiereus 25. 28. 33. 49. 53. 65. 66. 97. 98. 117. 131. 134. 138. 146; hiereus pro poleos 104; hieromnemon 77; hieropoios 83. 98; kanephoros 98; leitoreuon 134; neokoros 22; philagathos 138

cult regulation: 22.68 .69 .87 .98 .107 .131 ; fine for violation: 87

curse: cf. s.v. defixio, imprecation

dance: 4

death: 22. 35. 54. 58. 118

dedication: 71; label on: 118; objects: athletic prize: 119; booty: 27; bowl: 75. 91; club: 27; hydria: 119; jumping weight: 82; lamp: 15; lance: 105; mirror: 60; panoply: 16; phallus: 134; shield: 107 
Aphrodite: 22. 27. 87. 134; Basileia 55?. 92; Demie 108; Pandemos 27; Paphie 118. Apollo: 1. 6. 22. 27. 28. 34. 48. 56. 66. 67. 80. 139; Agreus 134; Didymeus 55. 91; Erethimios 13; Hetdomaios (Hebdomaios) 134; Lykeios 103. 107. 134; Smintheus 94; Tyritas 20. 52. Ares: 88. Artemis: 44. 119. 134; Iberia 27; Patmia: 99; Pergaia 25; Progonike 86; Soteira 134; Stratia 134; Throsia 134. Asklepios: 22. 27. 65. 86. 98. 139; Epekoos 111. Athena: 22. 27. 51.78. 115. 129; Agoraia 134; Dexamena 105?. Lindia 13; Nikephoros 64; Oreia 110; Pallas 137; Polias 7; Pronaia 107; Soteira 98. Basile: 98. Chiron: 139. Daimon Athanatos: 134. Demeter: 117. 118. 119. 134; Zemiea 87. Dike: 88. Dionysos 4, 41?. 52. 100. 103. 107. 134; Kathegemon 81. Dioskouroi 27. 119. Eileithyia: 50. 60. 61. 115. Ennodia: 131. Ge: 19; Pantareta 134. Hekate: 19. 86; Epitymbia 39; Soteira 1. Helios: 13. 134. Hera: 4. 9. 29. 41. 86. 100. 133; Basileia 92; Teleia 27. Hera Neotera: 4. Herakles: 2. 27. 50. 119. 134. 139. Hermes: 22. 27. 118. 139; Chthonios 134; Eriounios 39. 134; Kyllanios 22. Heros: 40. Hestia: Boulaia 32. Hosion kai Dikaion: 86. Hygieia: 27. 65. 86. 98. 139. Idaioi Daktyloi: 114. Kephisos: 142. Kore: 33. 53. 118. 134. Kronos: 104. Leukathea: 134. Mes Askainos: 140. Meter Oreia: 114. Meter Phrygia: 92. Meter Theon: 134. Basileia 92. Muses: 118. Nemesis: 47. 53. Nymphs: 41. 74. 85. 102. 134. 139; Naiades 134. Ophthalmotheoi: 37. Pan: 74. 139. Pantheion: 25. Parthenos: 27. 112. Persephone: 22. 127. Plouton: 33.53. 118. 127. Poseidon: 27. 46. 134; Hippios 13; Isthmios 66; Patrageneus 134. Selene: Epekoos 109. Thea Rhome: 10. 73. Themis: 118; Agoraia 134. Theoi/Theai: Hapantes 134; Pantes 25; Pasai 134; Patroioi 134. Theos Hypsistos: 86.93 . Tyche: 22 . Zenoposeidon: 119. Zeus: 3. 8. 9. 36. 41. 49. 60. 119. 131; Bouleus 27; Hellanios 119; Homoloios 134; Idrieus 29; Kataibatas 134; Labraundos 135; Megistos 27. 120; Morragetas 134; Osogo 135; Pantheios 22?; Patroios 33. 126; Progonikos 117; Soter 22. 44. 98. 120; Spaloxios 33; Tharaios 134; Thaulios 134; Tritodios 134; Tropaios 27; Xanthios 22?

deities, Anatolian: Gergas: 79; Thea Lotiane: 85; Toubassis: 76; Zeus Auoreanos: 86; Zeus Bennios: 97; Zeus Bronton: 85; Zeus Okkenenos: 85; Zeus Sarnendenos: 11; Zeus Syrgastes: 11; Zeus Trossou: 3; Egyptian: Isis: 15. 17. 22. 26. 27. 134; Sarapis: 134; Iranian: 140: 140; Phoenician: Balmarkod: 4; Sima: 4; Oriental: Astarte: 22; Zeus Kodopas: 110; Zeus Sabazios: 53; Roman: Diana: 118; Juno Regina: 4. 41; Juppiter Optimus Maximus: 4. 41. 120; Mars: 118; Mercurius: 118; Silvanus: 41. 101; Venus: 118; Thracian: 41; Thracian Rider God: 40. 41; Zeus Dalbenos: 101 


$$
\text { imprecation }
$$

47 gem: 106

48

ephebe: 47

fate: 22.54 .58

funeral: 58

grove: 22.139

healing: 15

heroon: 24

hymn: 114

incubation: 53

inventory: 98

Jews: 93

land, sacred: 57

libation: 41

oath: 59.62

endowment: 3.65

epithets, distinguishing between gods with the same name: 33

festival, funding of: 135; gymnasiarchos serving during f.: 146

festival: Dionysia: 42 (Samothrake); Panathenaia 98; see also s.v. agonistic festival

foundation legend: 66

founder, cult: 3.9

funerary cult: 1 4. 9. 22. 70. 86. 89; freedman and funerary cult: 5; sacrifice: 70; cf. s.v. gladiatorial combat: 86

grave, protection of: 22

hero: 24 (Opheltes). 107 (Panoteus); 108 (Angelos). 117 (Bolbenos, Kerdypyros). 119 (Protesilaos). 134 (Poliphylax, Protesilaos)

heroization: 28.70

imperial cult: 12.25 .27 .28 .44 .49 .64 .86 .90 .113 .133 .134 .146 ; member of the imperial family assimilated with divinity: 133 (Livia-Hera)

imprecation, funerary: 9. 22. 84. 118

incense-burner: 64.72

justice, divine: 37.59 .88 .118

lamp, dedication of: 15

lease of sacred land: 57

lex sacra: see s.v. cult regulation

manumission, dedication upon m.: 64; through dedication: 27

magic: 63. 68. 106. 108; cf. s.v. amulet, defixio

mystery cult: 42.81

myth: 66. 107.114. 118 


\section{Greek Words (a Selection)}

oracle: 89.107

Orpheus: 41

'Orphic'/Dionysiac text: 127

paganism, late: 118

perjury: 59

piety: 139

prayer for justice: 23

priesthood, for life: 66; hereditary: 25.29

priestood, priest funding a temple: 33.65

procession: 25. 98. 117. 131

purity: 15.68 .69

religious conflict: 118

sacrilege: 70

spring: 15

statue: 4 ; cult s.: 33.65

theoria: 42

torch-race: 47

vow: 15

war, interruption of rituals: 145

water: 15

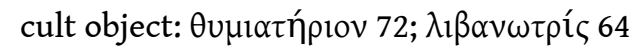

priest: 3. 9; list of p.: 13. 66; see also s.v. cult personnel

ruler cult: 57 (Philip II). 85 (Alexander and Olympias). 145 (Ptolemies)

sacrifice: 3. 5. 70. 98. 107. 116. 131; burning of the victim: 5; distribution of meat: 117;

food offering: 87; interrupted because of war: 145; shared experience: 134

sanctuary, boundary marker: 6.87 .130 .134 ; building account: 77; cleaning of: 98; founded by woman: 142; land of: 57. 135; property of s., mortgaged: 76; revenues of: 135 . 147; royal supervision of: 147 ; cf. s.vv. asylia, grove, inventory

temple, building process: 55 ; funded by priest: 33.65

woman, founder of sanctuary: 142; rite of passage: 134

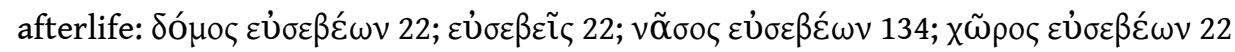

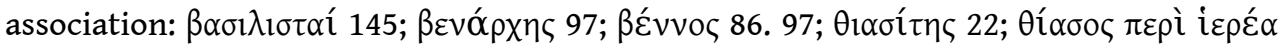

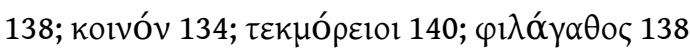

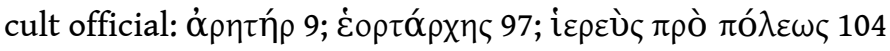

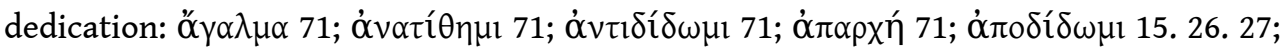

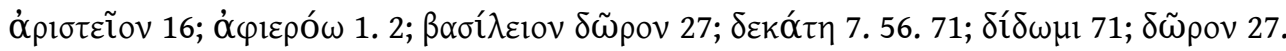

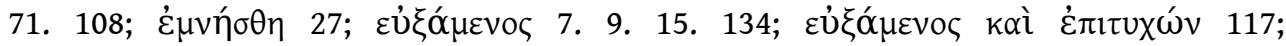




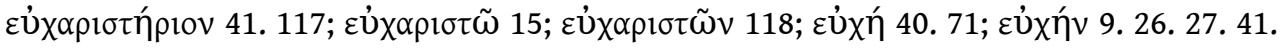

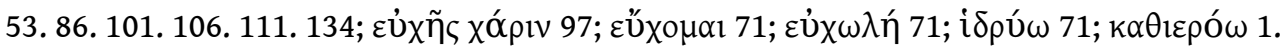

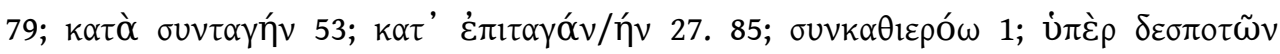

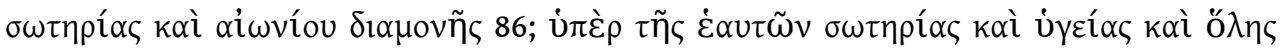

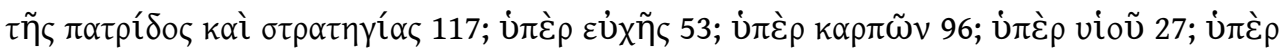

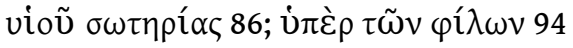

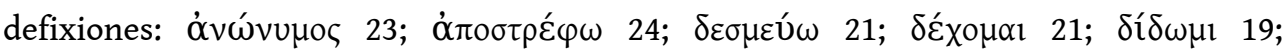

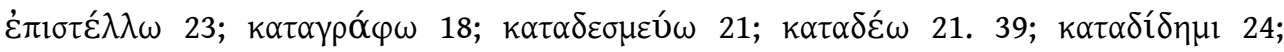

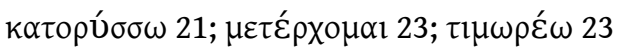

divination: ỏ $\rho v \varepsilon o \sigma \kappa o \pi \varepsilon ́ \omega 117$

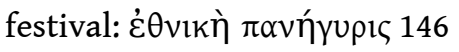

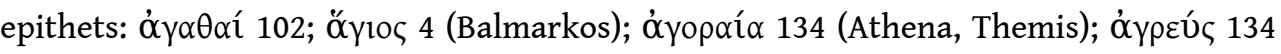

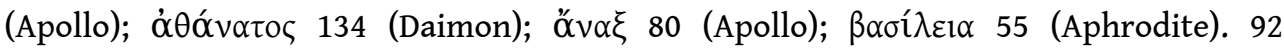

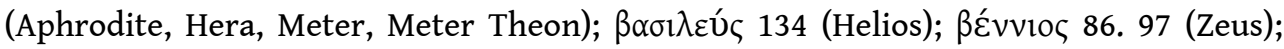

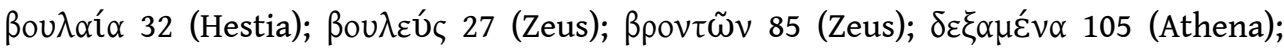

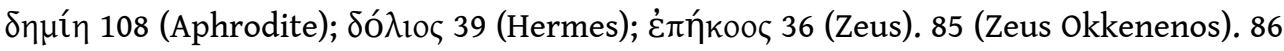

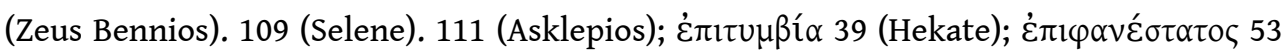

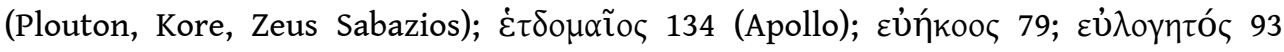

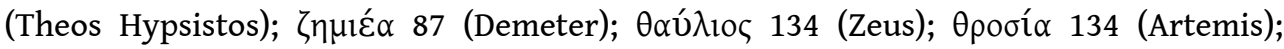

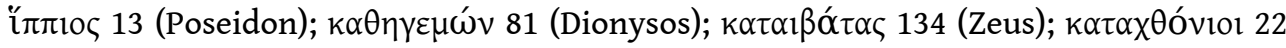
(Theoi); kupía 9 (Hera); kupí 86 (Hekate); kúpıos 4 (Balmarkos). 117 (Asklepios, Heros);

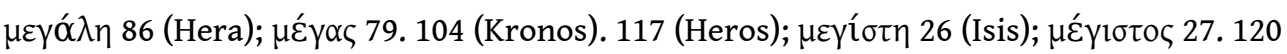

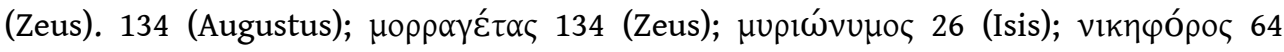

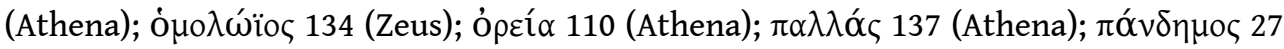

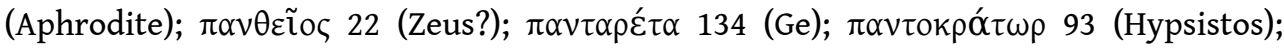

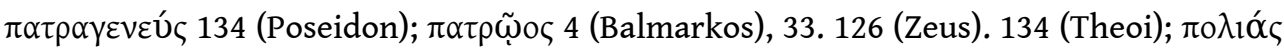

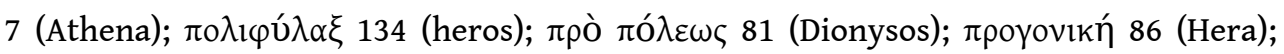

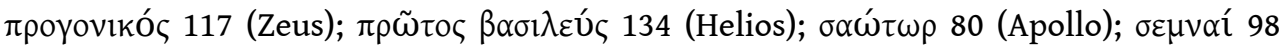

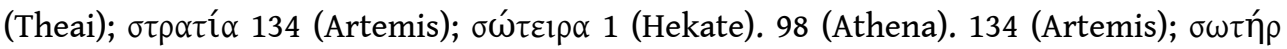
22. 44. 98. 120 (Zeus). 57 (Philip II). 65 (Asklepios, Hygieia). 134 (Augustus); $\tau \varepsilon \lambda \varepsilon i ́ \alpha 27$

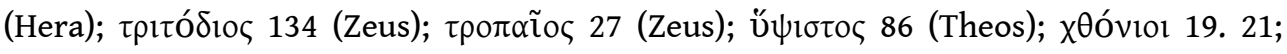

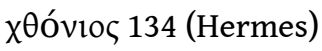

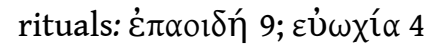

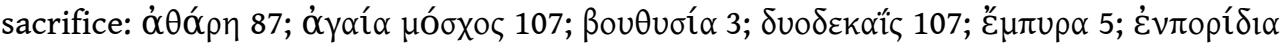

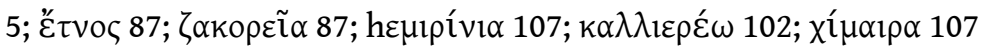

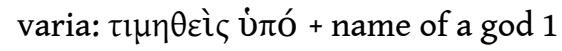

1) M. ADAK, "Phrygische und lydische Denkmäler im Museum von Çeşme", Philia 2 (2016), p. 123-130 [BE 2017, 538]: A. publishes an inscribed funerary relief of unknown provenance in the Museum of Çeşme (2nd/3rd cent.). The text reports that Tatis and

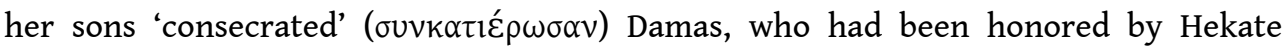

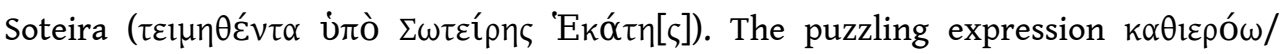

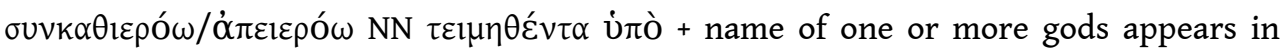
eight inscriptions from the Upper Tembris Valley. In five cases, the divinity is $\Sigma \omega \tau \varepsilon i ́ p \eta$ 'Ekó $\tau \eta$, in one case Apollo, in another Zeus, and in the case of the priest and prophet Epitynchanos (SGO III 16/31/10) three gods (Hekate, Manes Daos, Zeus' Heliodromos, 
and Phoibos). In one case the 'consecration' occurred while the honored person was still alive (Pfuhl-Möbius 2091: ع้ $\tau 1 \zeta \tilde{\omega} \sigma \alpha v$ ) [this shows that $\kappa \alpha \theta 1 \varepsilon p o ́ \omega$ means to set up the funerary monument, in this case, in a person's lifetime]. A. suggests that this expression refers to extraordinary gifts given by the gods, perhaps in a dream or vision - in the case of Epitynchanos this was the gift of divination. [As J. MORALEe, "The Usefulness of Danger in Hellenistic and Roman Epigraphy", Mnemosyne 72 (2018), p. 84113 , has shown, rescue by a god elevated an individual's status (cf. Achilleus Tatius VI, 13, 2; VIII, 3, 1; Heliodoros, Ethiopica X, 17, 1-2)].

112 2) Y. AKIN, "Eine Heraklesweihung aus dem Hinterland von Limyra", Philia 2 (2016), p. 137-142: A rock-cut inscription on the eastern slopes of Mt. Alacadağ (territory of

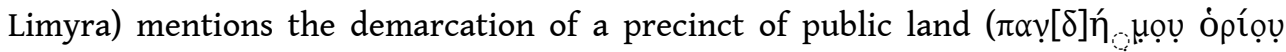

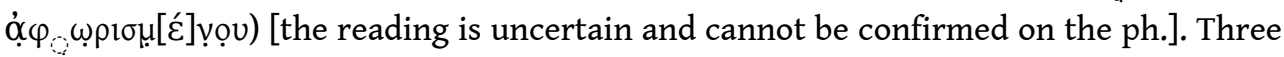

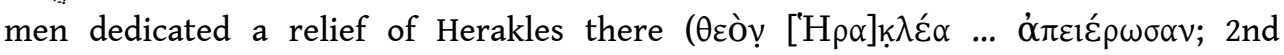
cent. CE).

113 3) E. AKINCI ÖZTÜRK, H.H. BAYSAL, and M. RICL, "A New Attestation of the Cult of Zeus Trossou in a Public Inscription from the Maeander River Valley (Çal Ovasi)", Gephyra 12 (2015), p. 191-198 [BE 2016, 478; SEG LXV 1248]: Ed. pr. of a decree from Atyochorion in Phrygia (2nd cent. CE) concerning the establishment of an endowment. The stele, set up in the sanctuary of Zeus Trossou, records an endowment made by Eukopos; the capital

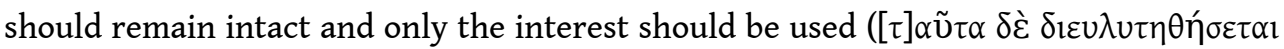

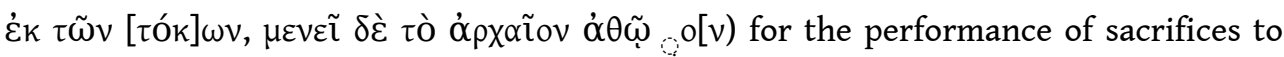

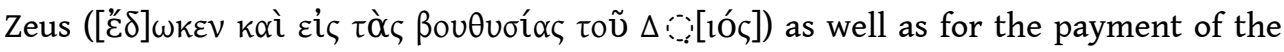

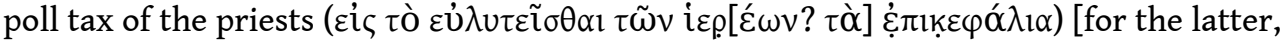
a very unusual use of the money of an endowment, see the comments of P. HAMON, BE 2016, 478].

4) J. ALIQUOT, "La fête au village : un nouveau regard sur le culte de Balmarcod à Deir elQalaa (Liban)", in A.-M. MAïLA-AFEICHE (ed.), Cult and Ritual on the Levantine Coast and its Impact on the Eastern Mediterranean Realm. Proceedings of the International Symposium, Beirut 2012, Beirut, 2015, p. 539-557 [BE 2015, 700; SEG LXV 1632-1635]: A. offers an overview of the inscriptions of a sanctuary of the Phoinician cult of Balmarkos (Balmarkodes) at Deir el-Qalaa, near Berytos. A. presents the ed. pr. of a bilingual dedication to this ancestral god $(\theta \varepsilon \tilde{\omega} \pi \alpha \tau \rho \omega \omega)$; Genio populi, in the Latin text), the

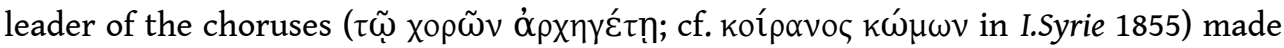
by the cult association of the Maximitai (probably named after its founder; Imperial

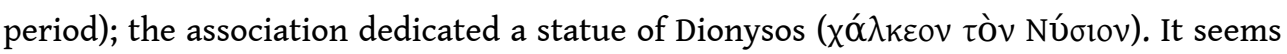

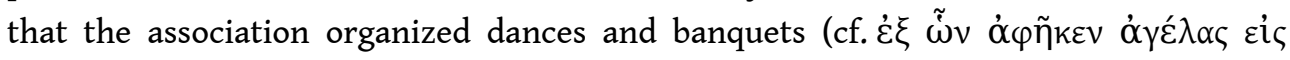
$\varepsilon \dot{U} \omega x i ́ \alpha v)$. Another bilingual inscription (I.Syrie 1855, 2nd/3rd cent.) is addressed to Juppiter Optimus Maximus Balmarcod. The dedication was a fountain-mouth in the

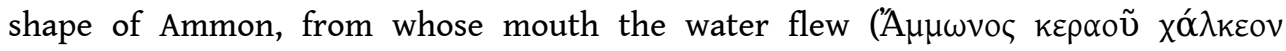

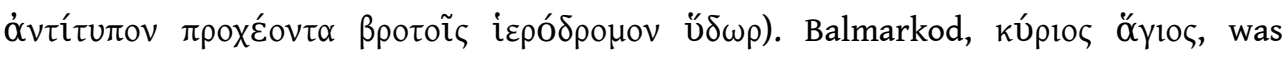
worshipped in this sanctuary together with Hera (Iuno Regina), the goddess Sim[a], and Hera Neotera.

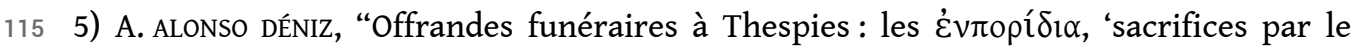
feu', dans IThesp. 215", REG 129 (2016), p. 63-83 [BE 2017, 263]: An inscription from Thespiai (I.Thespiai 215, Hellenistic) records the manumission of a slave by Aristodama, following the wish of her deceased son, under the condition that the freedman 
conducts the funerary cult for his former masters. His obligations included $\dot{\varepsilon} v \pi$ topí $\delta 1 \alpha$

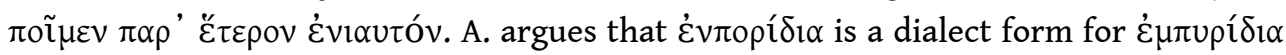

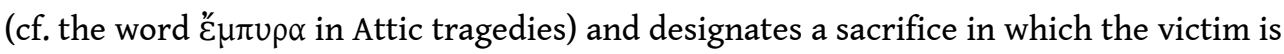

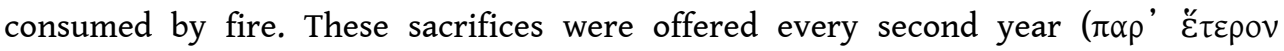
$\dot{\varepsilon} v 1 \alpha u \tau o ́ v$ ), on the anniversary of the funerals of the two masters (' "un jour anniversaire sur deux" des funérailles des ses anciens maîtres') [doubtful; also, the sacrifices were more likely offered on the birthdays of the masters, not on the anniversary of their funerals; for commemorative days on birthdays, see e.g. EBGR 2006, 51; 2010, 131, 143; IG XII. 4.1184].

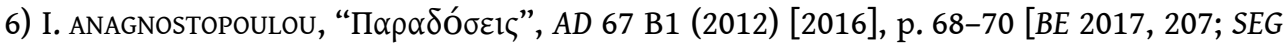
LXV 131]: A. reports the delivery of a column from the area of Acharnai (Athens), inscribed on one side with a boundary marker of a private property, indicating its

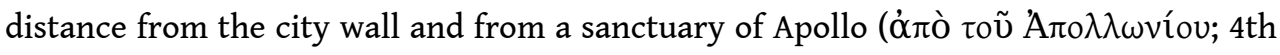
cent.); the column was later used as the tombstone of a Christian priest.

7) M. ARSLAN and N. TÜNER ÖNEN, "2013 Yllı Phaselis Antik Kenti ve Teritoryumu Yüzey Araştırması", AST 32.2 (2014), p. 289-300 [SEG LXIV 1408]: The A. mention a dedication found on the acropolis of Phaselis, the oldest known inscription of the city (p. 290; ca.

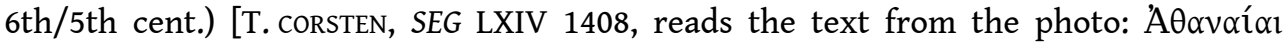

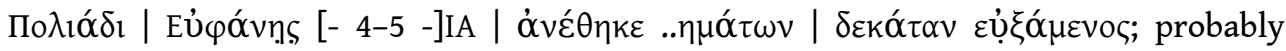

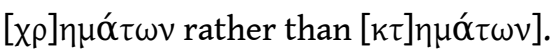

8) S. ATEşLIER, "On the Excavations of the Zeus Temple of Alabanda", Anatolia Antiqua 22 (2014), p. 247-254 [BE 2015, 41; SEG XLIV 895]: The temple at Alabanda, long believed to be a temple of Artemis, must in fact be attributed to Zeus, as may be inferred from the double axes engraved on blocks and altars and from the letters $\Delta \mathrm{I}(\Delta \mathrm{l}(\mathrm{o} \varsigma)$ or $\Delta \mathrm{l}(\mathrm{i})$ repeated three times on the north stylobate.

119 9) A. AVRAM, "Ein Altar aus Nakoleia und seine griechisch-phrygischen Inschriften", Gephyra 12 (2015), p. 199-229 [BE 2016, 484; SEG LXV 1264]: Ed. pr. of an altar with reliefs and inscriptions in Greek and Phrygian on all sides (Nakoleia, 3rd cent. CE). On side A, a standing bearded man (the dedicant) holds two rods, indicating his priestly status. The Greek text reports that Brogimaros (a Celtic name), son of Epikrates, dedicated the altar to Zeus of Brogimaros and Kyria (Hera?) in fulfilment of a vow and as his memorial

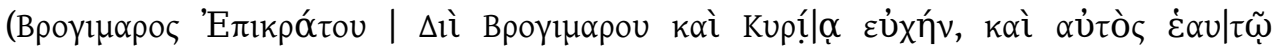
$\mu v \eta \mu o ́ \sigma u v o v)$. This is another example of a cult named after its founder. From the Phrygian text, added by Brogimaros' son, one may infer that the altar was set up in the burial grounds of Brogimaros and his family. A Phrygian funerary imprecation threatens violators of the grave with divine punishment. On side B, a relief represents the bust of a woman (Brogimaros' wife?); a metrical inscription refers to the dedication

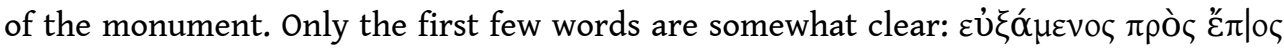

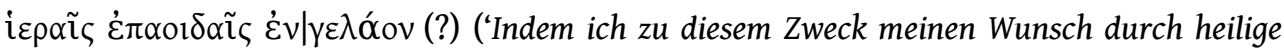
Beschwörungen ausgesprochen habe...'). The relief on side C represents a young man holding a papyrus scroll (Brogimaros' son?); the inscription is only partly preserved. Finally, on side D a relief portrays the bust of a young woman (daughter of Brogimaros?). An epigram refers to the dedicant, designating him as priest of Zeus and informing the reader that Brigimaros stayed in that place, among the blessed fruits: B. oүıน

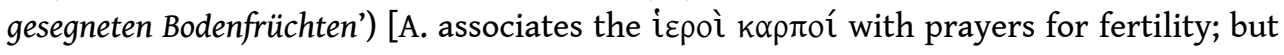




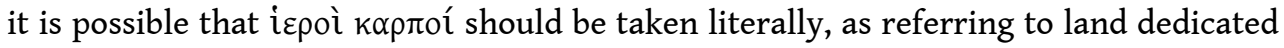
to Zeus, whose cult Brogimaros had founded].

10) A. AVRAM, "Neue Inschriften aus Tomis", ZPE 197 (2016), p. 140-148: Ed. pr. of an honorific inscription for a priest of Thea Rhome (Tomis, ca. $180 \mathrm{CE}$ ). This is the first attestation of the cult of Dea Roma in Tomis.

11) A. AVRAM, "Two Phrygian Gods Between Phrygia and Dacia", Colloquium Anatolicum 15 (2016), p. 72-82 [BE 2017, 526]: A. discusses the epigraphic evidence for the diffusion of the Phrygian cults of Zeus Syrgastes or Syrgasteios (attested in Gordion, Tios, and Hadrianopolis) and Zeus Sarnendenos (attested in Phrygia, Galatia and Dacia).

12) A. AVRAm and M. IONESCU, "Nouvelles inscriptions de Callatis", in A. ROBU and I. BIRZESCU (eds.), Mégarika. Nouvelles recherches sur Mégare et les cités de la Propontide et du Pont-Euxin, Paris, 2015, p. 451-466 [BE 2017, 128 and 369; SEG LXIII 531]: The A. republish an inscription from Kallatis (1; originally published by S. Yu. SAPRYKIN and I. PYSLARU, Problemy istorii, filologii, kul'tury 40 [2013.2], p. 168-182). The text commemorates the

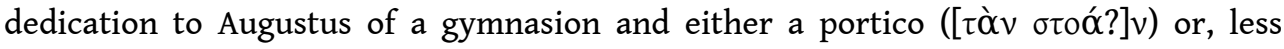

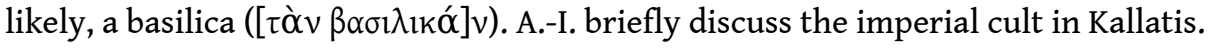

13) N. BADOUD, Le temps de Rhodes. Une chronologie des inscriptions de la cité fondée sur l'étude de ses institutions, Munich, 2015 [BE 2016, 66; SEG LXV 640]: We briefly note this comprehensive study of Rhodian chronology, based on the epigraphic material, since it is highly relevant for the priestly offices and the cults and festivals of Rhodes. In an appendix (p. 305-453), B. presents critical editions of 72 texts on which his study is based. B. discusses inter alia the Rhodian calendar (p. 11-35), and the lists of the priests of Helios in Rhodes (SEG XII 360), Apollo Erethimios in Ialysos (IG XII.1.730), Athena Lindia (I.Lindos 2), and Poseidon Hippios (IG XII.1.926+929).

14) N. BADOUD, M. FINCKER, and J.-C. MORETTI, "Les monuments érigés à Délos et à Athènes en l'honneur de Ménodôros, pancratiaste et lutteur", BCH 139/140 (2015/2016), p. 345416 [BE 2017, 261, 402]: The A. propose a reconstruction of the honorific monuments for the pankratiast and boxer Menodoros in Athens (IG II ${ }^{2}$ 599) and Delos (I.Délos 1957). The monuments consisted of bases, on which the victories of Menodoros were inscribed within crowns, and statues showing him in combats (ca.120-110). The A. discuss the career of Menodoros in the context of the history of athletic contests in the late 2nd cent. The honorific monuments recorded 35 (or 32) victories in contests in Greece, Delos, and Euboia: Eleusinia, Panathenaia, Heraia in Argos, Lykaia, Olympia, Nemea, Eleutheria, Herakleia in Thebes, Trophonia in Lebadeai, Pythia and Soteria in Delphi, Naa in Dodone, Nymphaia in Apollonia, Delia, and Rhomaia in Chalkis.

15) R.S. BAGNALL et al., Graffiti from the Basilica in the Agora of Smyrna, New York, 2016 [BE 2017, 145]: Ed. pr. of the graffiti and dipinti found on the walls of the cryptoporticus of a basilica in Smyrna (late 2nd/early 3rd cent. CE). Eight graffiti refer to eyes and the healing of eye diseases (T12.2, 14.1, 14.3, 15.4, 16.1, 27.1, 27.2; TP 103.2; p. 42f.). In several cases the healing is explicitly mentioned, as is gratitude to a spring named Baite

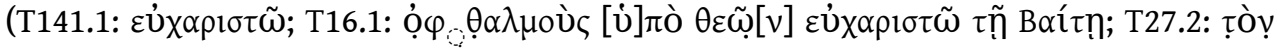

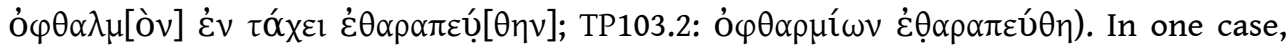

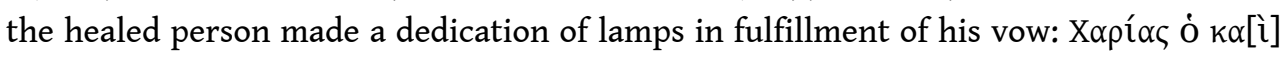

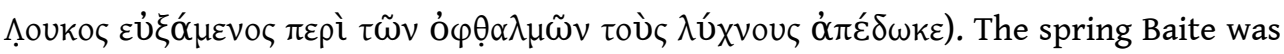
regarded as sacred, as may be inferred from a graffito that refers to it as "possessed by

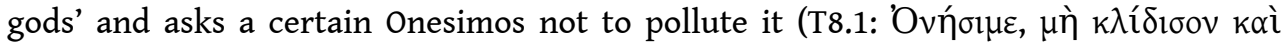




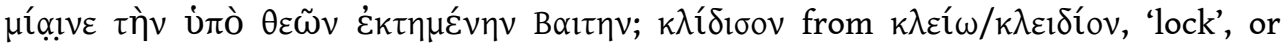

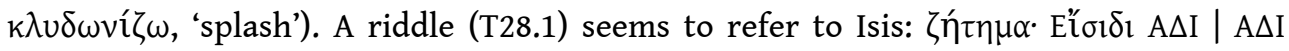

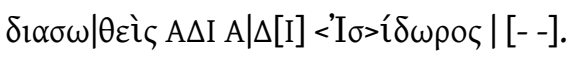

16) P. BAKER and G. THÉRIAULT, "Note sur le décret béotien SEG 26, 130, l. 10", ZPE 195 (2015), p. 82-84 [BE 2016, 228; SEG LXV 99]: A fragmentary decree from Boiotia found in

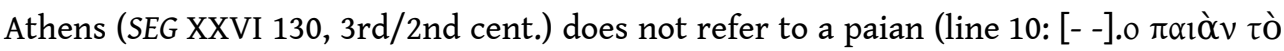

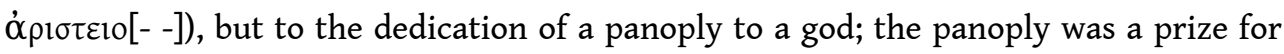

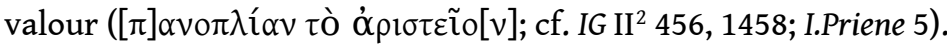

17) A. BARTA, "Milites magistratusque: A New Curse Tablet from Savaria", ACD 48 (2012), p. 167-173: Ed. pr. of a curse tablet from the Isis sanctuary of Savaria (reign of Vespasian). The tablet was found folded seven times. The text is very fragmentary, but on the obverse, one recognizes names and the words vibus and vita, and on the reverse the words milites magistratusq[ue]. No other curse tablet is known to be addressed against soldiers and magistrates.

18) A. Belousov, M. DANA, and N. NiKolaev, "Deux nouvelles defixionum tabellae du territoire d'Olbia du Pont”, ZPE 197 (2016), p. 167-177 [BE 2017, 384]: Ed. pr. of two curse tablets from Olbia. The first lead tablet was folded four times. The defigens curses ca. 33 enemies, mostly men, whose names are written in the nominative, and binds

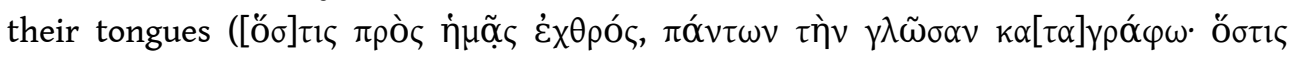

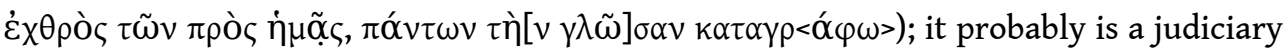
curse tablet. The second tablet, folded twice, only contains 7 names (ca. 350-300).

19) A.V. Belousov and N.F. Fedoseev, "A New Defixio from Ancient Panticapaeum's Necropolis", ACSS 22 (2016), p. 18-25 [BE 2017, 387]: Ed. pr. of a curse tablet, folded four times and pierced by a nail, found in the cemetery of Pantikapaion (4th cent.). The defigens curses the wife of Lenaios, his and her brothers, Glaukias, his sons, and any

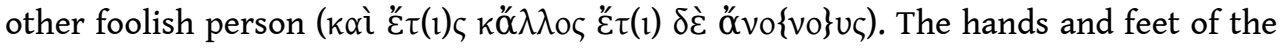

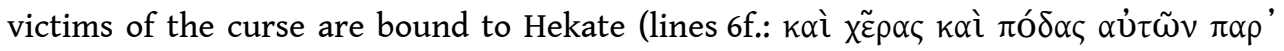

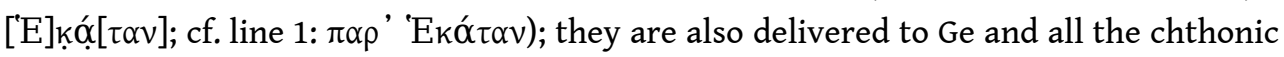

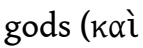

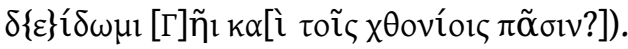

20) F. BERLINZANI, "Due iscrizioni votive dalla Periecia laconica. Competenze di scrittura in Laconia in età arcaica e classica", in A. INGLESE (ed.), Epigrammata 3. Saper scrivere nel Mediterraneo antico. Esiti di scrittura fra VI e IV sec. a.C. in ricordo di Mario Luni. Atti del convegno di Roma. Roma, 7-8 Novembre 2014, Rome, 2015, p. 25-49: B. discusses the dedication of a vase to Apollo Tyritas in Tyros in Lakonia (IG V.1.1521, ca. 525-510; cf. EBGR 2015, 61). The dedicant was the Spartan prince Dorieus, the scribe possibly a member of the elite of the perioikoi. In the case of the dedication to Apollo Hyperteleatas from Phoinike (SEG II 170, ca. 500-450), B. expresses doubts on the metrical structure of the text and argues that the sculptor's name was Kyranaios, a perioikos. His name suggests connections between Lakonia and Kyrene.

131 21) G. Bevilaqua, "Phileros e gli altri: una nuova defixio greca di Roma", Arch. Class. 66 (2015), p. 493-510 [BE 2017, 149]: Ed. pr. of a folded tablet from Rome (same location as SEG LXIV $875=$ EBGR 2014, 20) with a curse addressed against the teacher $(\pi \alpha 1 \delta \alpha \gamma \omega \gamma o ́ \varsigma)$ Phileros, his wife, and two other men (1st cent. CE). The defigens buries and binds down the tongue, power, hands, and feet of Phileros in a cold grave and a hot pyre

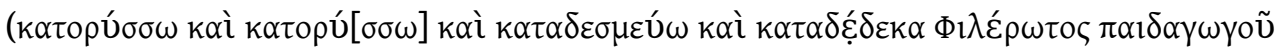




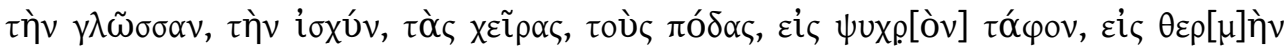
$\pi u \rho \alpha ́ v ;$ cf. SEG LXIV 875). The gods of the underworld are asked to receive the cursed

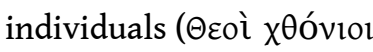

$[\delta] \varepsilon ́ \xi \alpha \sigma \theta \varepsilon$ etc.). The defigens binds their tongues, professional activities, and power, in

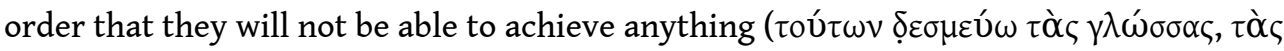

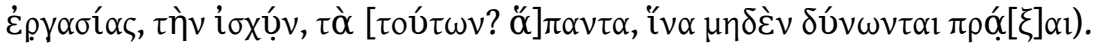

21 bis) W. BLÜMEL, “Zu der neuen Inschrift aus Pidasa”, EA 49 (2016), p. 106-108: See infra no. 76.

22) D. BOSNAKIS and K. HALLOF, Inscriptiones Graecae Insularum Maris Aegaei praeter Delum. Volumen XII. Fasciculus IV. Inscriptiones Coi, Calymnae, Insularum Milesiarum. Pars III. Inscriptiones Coi, Insulae. Tituli sepulcrales urbani, Berlin, 2016 [BE 2017, 416]: The third fascicule of IG XII.4 assembles 1814 epitaphs from the city of Kos. Many texts provide information on religious matters; those that have already been presented in EBGR 2007, 132 and 2008, 19, are not included in the following summary. Sanctuaries: A very fragmentary (funerary?) epigram mentions the grove in the sanctuary of Apollo

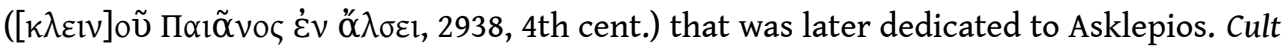
regulations: A stele, reused as an epitaph, was originally used for a cult regulation ( ${ }^{*} 1844$ I, 3rd cent.), the text of which is very fragmentary. One recognizes references to Aphrodite (line 5), a sanctuary (line 6), and possibly a ritual (line 4: $\tau \varepsilon \lambda \varepsilon[--])$. Contests:

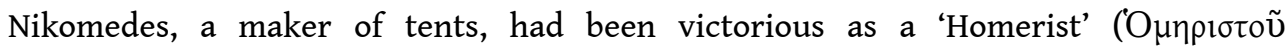
iepovíkov; *2338, 1st cent. CE) [we know that Homerists, mimes who imitated Homeric battle scenes, performed in theaters (Athenaios XIV 620b; C. ROUECHÉ, Performers and Partisans at Aphrodisias, London, 1993, p. 22; M. HILlGRUBER, "Homer im Dienste des Mimus", ZPE 132 [2000], p. 63-72), but this is the first reference to the participation of Homerists in sacred contests. This inscription must be later than the 1st cent. CE; pantomimes first competed in contests in ca. 176 CE (see EBGR 1997, 348), and it is

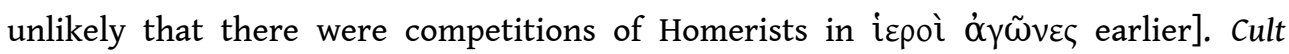
personnel, cults: Epitaphs of an agonothetes (2413, 2nd cent. CE) and a neokoros (3047, 3rd cent. CE) [to judge from the name (Paideros) and the absence of a patronymic, a slave, probably serving in the sanctuary of Asklepios]. Associations: Numerous boundary

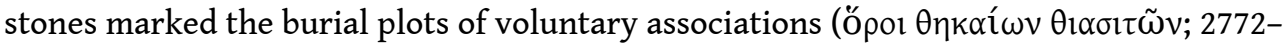
2826). In addition to the associations mentioned in EBGR 2007, 132 and 2008, 19, there are associations of Agathodaimonistai $\left(2802,{ }^{*} 2804,{ }^{*} 2805\right)$, Aphrodisiastai (2785-2786), Apolloniastai $(* 2782)$, Asklapiastai $(* 2806, * 2807)$, Athenaiastai $(2816,2820, * 2821)$, Hermaistai (2796), Isiastai (2822), and worshippers of Tyche Aphrodite (2798, *2799),

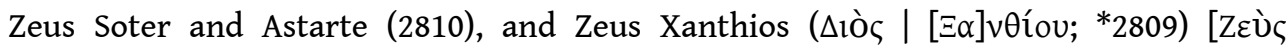

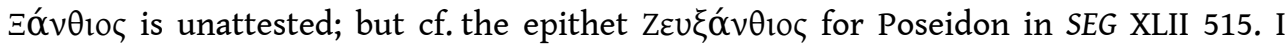

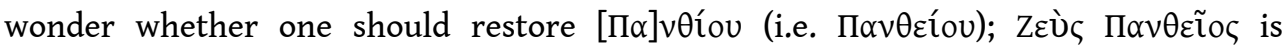
attested in Kyrene (SEG XX 719 = LSS 116 line 12)]. Death and afterlife: Death is attributed to envious Fate (1499), to the Fates $(2576,2624)$, and to an envious daemon (1963*; ßó $\sigma \kappa \alpha v \varepsilon \delta \alpha(\mu \omega v)$; an epitaph uses the metaphor of Hades binding the deceased with

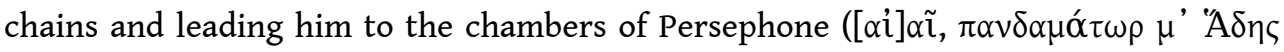

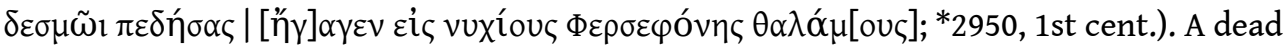

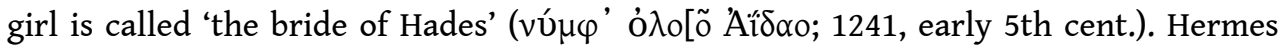
Kyllanios is asked to bring a young man, who died at the age of 18, to the place of the

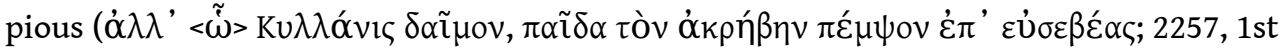

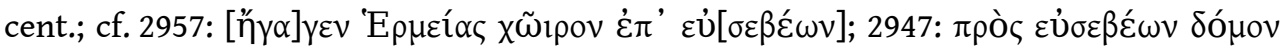


ä $\xi \varepsilon \tau \alpha l)$. A few epitaphs are dedicated to the gods of the underworld, under Roman

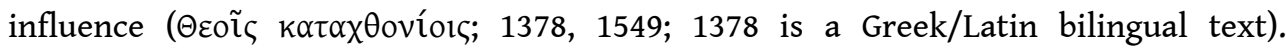
Funerary imprecations: A man invokes Zeus from his grave, asking him to bring

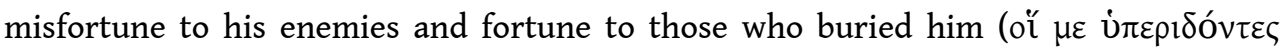

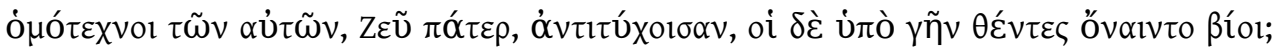
1444,1 st cent.). An epitaph uses a variant of a widespread curse: $\kappa \varepsilon[i ́] v o v \pi \tilde{\alpha} v$, ǒбov

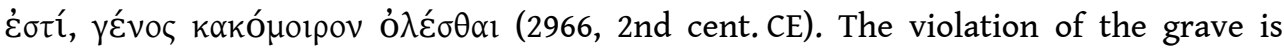

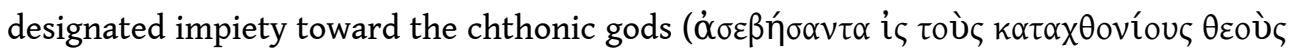

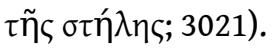

23) B. BRAVo and A. WOLICKI, "Un katadesmos du banquier Pasiôn", BCH 139/140 (2015/2016), p. 211-246 [BE 2017, 177, 388]: The A. republish a text written on a lead tablet (Athens, mid-4th cent.; SEG LIII 256), originally interpreted as a letter sent by the famous Athenian banker Pasion. In B.-W.'s convincing interpretation, this is not a letter but a curse tablet, with which Pasion requests the punishment of four men who were

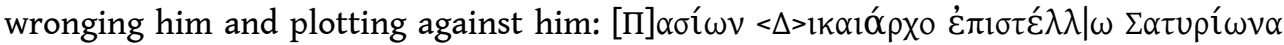

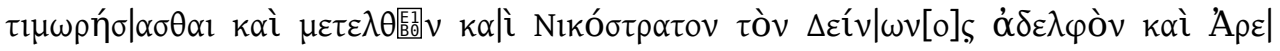

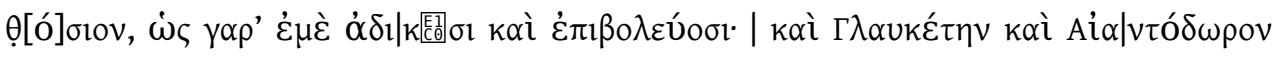

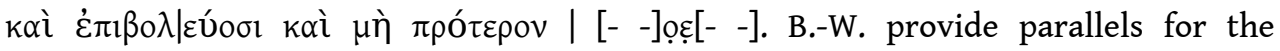
perception of curse tablets as letters sent to the gods of the underworld: DTA 102:

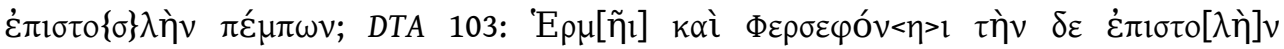
$\dot{\alpha} \pi о \mu \pi \varepsilon \dot{\varepsilon} \mu \pi \omega]$. The banker Pasion cursed men who were somehow associated with his elder son Apollodoros (cf. [Demosth.] LIII) [this would make this text one of the earliest 'prayers for justice'; the defigens identifies himself and justifies his action ( $\dot{\omega} \varsigma \gamma \alpha \rho$ ' $\dot{\varepsilon} \mu \grave{\varepsilon}$

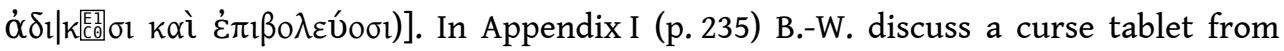
Pantikapaion, in which the word ó $v \omega ́ v v \mu o \zeta$ is repeated 18 times (SEG LIII 616; EBGR $2014,17)$. In their view, this word does not refer to the anonymous chthonic power to whom the tablet was addressed but to the people cursed by the defigens, whose identity was known to the chthonic demon. In Appendix II (p. 235f.), the A. mention a still unpublished text on a lead tablet found in a grave in Olbia (J. G. VINOGRADOv, "The Greek Colonization of the Black Sea Region in the Light of Private Lead Letters", in G.R. TSETSKHLADZE [ed.], The Greek Colonization of the Black Sea Area, Stuttgart, 1998, p. $153 f$. note 4). Vinogradov, who interpreted it as a private letter, has communicated the first

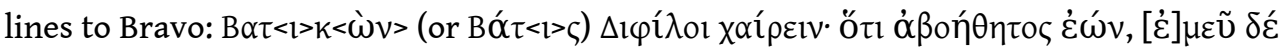

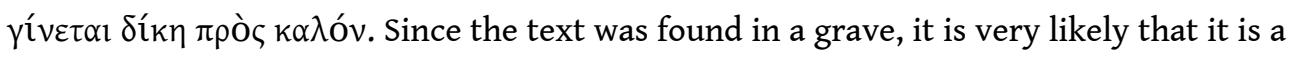
curse tablet in the form of a letter sent to a deceased man (Diphilos). [We note that the name of the deceased man in whose grave the tablet was deposited is also mentioned in

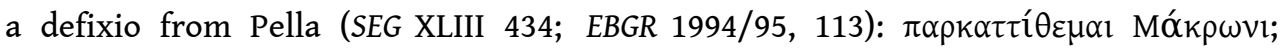
another similarity with the text from Pella is the defigens' reference to the lack of

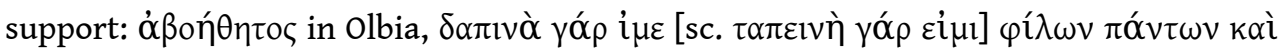
$\dot{\varepsilon} \rho \eta \operatorname{\mu \alpha }$ in Pella].

24) J.J. BRAVO III, "Erotic Curse Tablets from the Heroon of Opheltes at Nemea", Hesperia 85 (2016), p. 121-152 [BE 2017, 215]: B. studies four lead tablets with erotic curses found in the heroon of Opheltes in Nemea (SEG XXX 353 and three inedita). This location was probably chosen for the deposition of the tablets because of the legend concerning Opheltes' early and violent death. The first text aims at separating two lovers: 'I turn

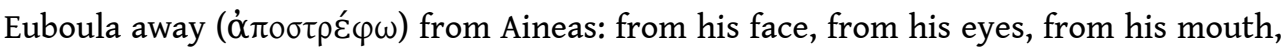
from his chest (new reading: $\dot{\alpha} \pi \grave{\alpha} \tau \tilde{\omega} v \tau \imath \theta \theta \hat{\imath}<\omega>v$ ), from his soul, from his belly, from 
his erect penis, from his anus, from all his body. I turn Euboula away from Aineas'. The second curse has a similar aim and uses, in part, similar language: 'I bind ( $\kappa \alpha \tau \alpha \delta i ́ \delta \varepsilon \mu \mathrm{l}$ ) the head of Diodoros to be turned away ( $\dot{\alpha} \pi \circ \sigma \tau \rho \alpha \varphi \tilde{\eta} \mu \varepsilon v)$ from Artemidora, his forehead, his eyes, his ears, his mouth, his chin, his arms. I bind the soul of Diodoros to be turned away from Artemidora, his belly, his body, his erect penis, his legs, his feet. I

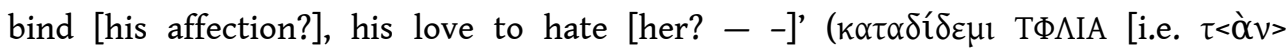

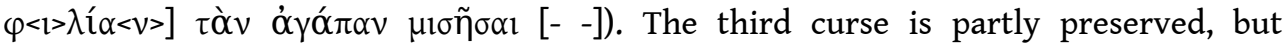
references to body parts, including the penis, show that the curse is erotic. Of the fourth tablet, only a few words and traces of letters survive, including $\dot{\alpha} \pi \circ \sigma \tau \rho \varepsilon ́ \varphi \omega$. B. discusses the ambiguity of these texts (desire and hatred) and the difficulties in determining who the object of the desire of the defigens was in the first two texts: the man or the woman mentioned in them? And is the first text to be seen in the context of

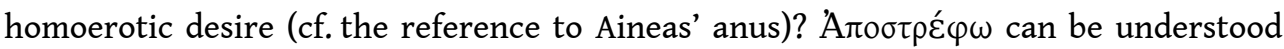
both in a physical sense (twisting back and incapacitating an opponent's body parts) and in the sense of turning away. B. prefers the latter interpretation, without excluding an ambiguity in the use of this verb.

25) H. BRU, Ü. DEMIRER, and N. TÜNER ÖNEN, “Inscriptions de Perge”, ZPE 199 (2016), p. 65-

82: Ed. pr. of 4 inscriptions from Perge. 1. The eds. reconstruct an inscription on four blocks of an architrave as a dedication of a building to the emperors and Artemis Pergaia founded by four former priests of the imperial cult and the high priest of the

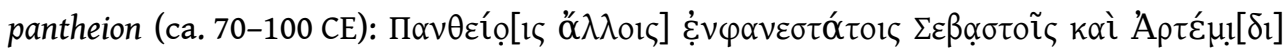

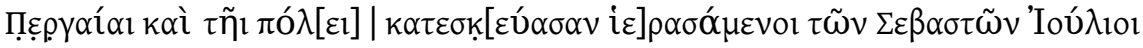

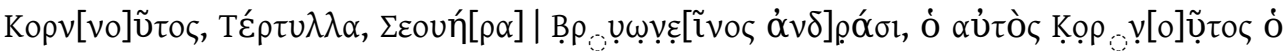

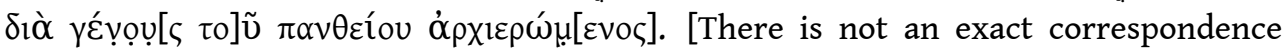
between this text and the eds.' translation: 'À toutes les divinités Augustes manifestes et à Artémis Pergaia et à la cité, les Iulii Cornutus, Tertulla, Severa, Bryoninus étant prêtres des Augustes ont érigé (le monument) par eux-mêmes, Cornutus étant quant à lui par hérédité

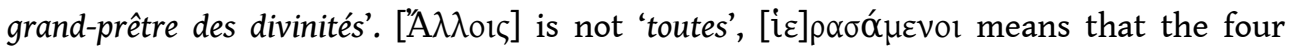

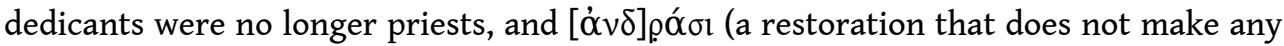
sense) is not translated. One of the dedicants was hereditary high priest of tò $\Pi \alpha v \theta \varepsilon \tilde{i} o v$, which is not 'les divinités' but the cult of an all-embracing divinity attested in Epidauros, Ephesos, Pergamon, and Savaştepe (see EBGR 2013, 114), possibly also in

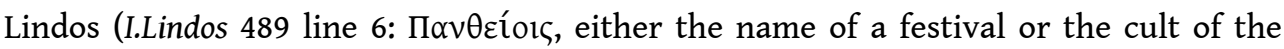

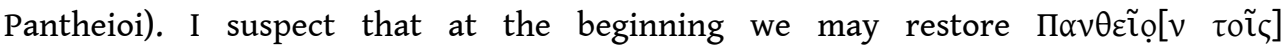

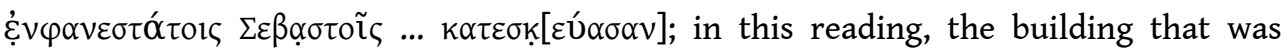
dedicated to the emperors, Artemis, and the city and on whose architrave the inscription was engraved was a $\Pi \alpha v \theta \varepsilon \tilde{o} o v$, a shrine for the worship of the Pantheion or

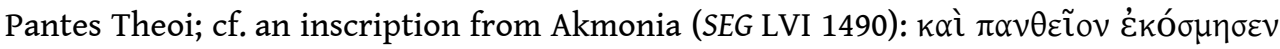

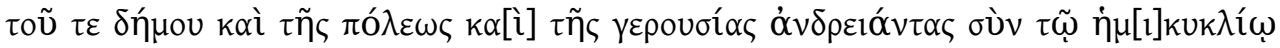

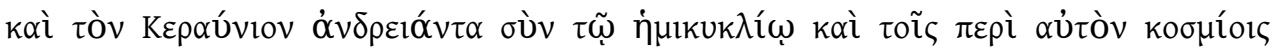
$\dot{\alpha} v \alpha \theta \dot{\varepsilon} v \tau \alpha$ ('and he adorned the Pantheion by dedicating statues of the Demos, the Polis and the Gerousia, together with the semicircular exedra, and the statue of Keraunios together with the semicircular exedra and the ornaments around the statue')]. The use

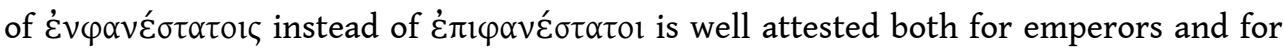
deities. 2. An honorific inscription for Claudia Lorentia, high priestess of Asia, daughter of the Asiarch Tib. Claudius Piso Tertullinus (mid-2nd cent. CE). 5. The eds. republish I.Perge 322, an honorific statue for Dragillianus. They interpret the words i $\varepsilon \rho \alpha \grave{\alpha} \pi \lambda \alpha \tau \varepsilon \tilde{\alpha} \alpha$ 
(line 8) as an indication that the colonnaded street $\mathrm{Jb}$ was used for religious processions

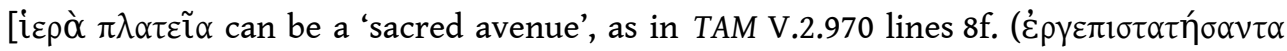
i $\varepsilon \rho \tilde{\alpha} \varsigma \pi \lambda \alpha \tau \varepsilon\left\{\hat{\alpha}_{\varsigma}\right)$, but here this term designates the dedicant, an association, the 'sacred association'. $\Pi \lambda \alpha \tau \varepsilon \tilde{\alpha} \alpha$ is a common designation of associations (e.g. $\pi \lambda \alpha \tau \varepsilon \tilde{\alpha} \alpha \tau \tilde{\omega} v$

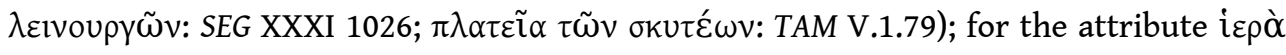

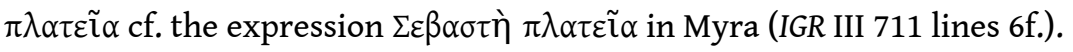

26) A. BRUGNonE, "La dedica a Iside da Lilibaio", Mare Internum 7 (2015), p. 99-108: Ed. pr. of a dedication to Isis Myrionymos $\theta \varepsilon \grave{\alpha} \mu \varepsilon \gamma$ í $\sigma \tau \eta$ from Lilybaion (2nd cent. CE); the text is inscribed on a column. It reports the dedication of a $\beta \tilde{\eta} \mu \alpha$ in fulfillment of a vow

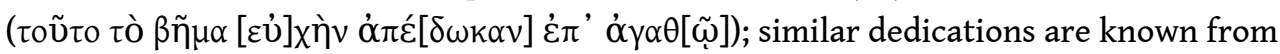
Delos and Kos (I.Délos 2080, 2103; IG XII.4.1263). It is not clear what object the column supported (a statue, a foot of Isis, an incense-burner).

27) P. CABANES, F. DRINI, and M. HATZOPOULos, Corpus des inscriptions grecques d'illyrie méridionale et d'Épire 3. Inscriptions d'Albanie (en dehors des sites d'Épidamne-Dyrrhachion, Apollonia et Bouthrôtos), Athens/Paris, 2016 [BE 2016, 280]: The eds. present a corpus of the inscriptions from small towns in north Epirus and south Illyria; inedita are marked with an asterisk. Phoinike: A dedication was made to Aphrodite (12). An inscription records a manumission that took the form of a dedication to Poseidon (8). Antiogoneia: There are four dedications: to Hermes and Herakles by a gymnasiarchos after his term in office (64), to Poseidon (66, عủXóv; 68), and to an anonymous god (67, ن் $\pi \dot{\rho} \rho$... vioṽ

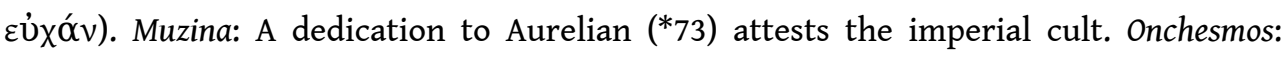
During the priesthood of Nike, a man dedicated a votive designated as tò $\beta \alpha \sigma i ́ \lambda \varepsilon o v$ $\delta \tilde{\omega}$ pov to Artemis Iberia (80, Hellenistic). Amantia: Dedications to: Zeus Bouleus (94), Aphrodita Pandamos (95-96, by a woman on behalf of their [= her and her husband's?] children), Poseidon and Amphitrita (98, عป̉xóv), Poseidon (99, by an association,

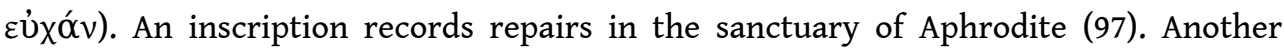
inscription refers to financial issues concerning the contests of Zeus (100) [for this text see my interpretation in EBGR 2011, 14 and SEG LXI 415]. Olympe: A dedication to Zeus Megistos by a board of magistrates after their term in office (128). Treport: A clay tile is inscribed with the name of Athena in the genitive; it was destined for a shrine of Athena (142). Orikos: A dedication to the gods (162). Borshi (fort at Sopot): A bronze club

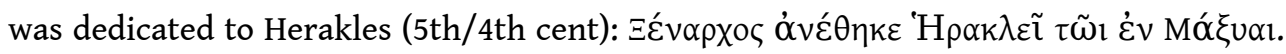

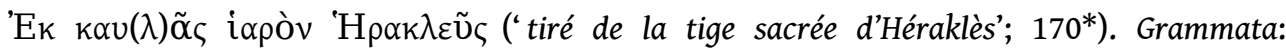
Numerous commemorative graffiti (171-266) were inscribed by sailors who invoke the

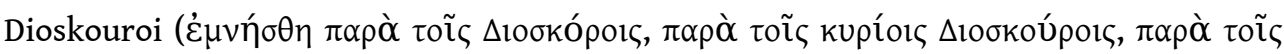
$\theta \varepsilon$ ĩ $\varsigma)$ on behalf of family members or themselves [see EBGR 2006, 22]. Two of the texts also mention Isis $(178,251)$. Byllis: Dedications to: Aphrodite $\left(303^{*}\right)$, Asklepios (311*,

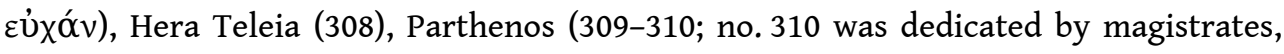

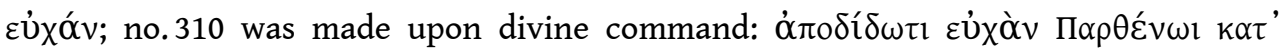

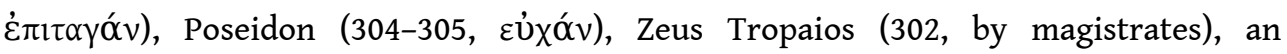

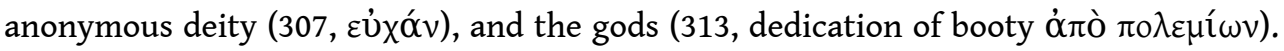
Dimale: A dedicatory epigram for Apollo (410; EBGR 1994/95, 95). Kashar (area of Tirana): A dedication to Zeus Megistos (435*). Memëlisht: A dedication to Asklepios and Hygieia

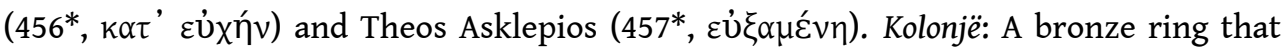

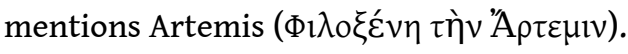




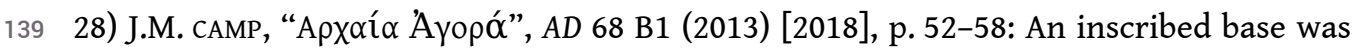
found in the Athenian Agora. Citizens belonging to the tribe Leontis honored Eukles,

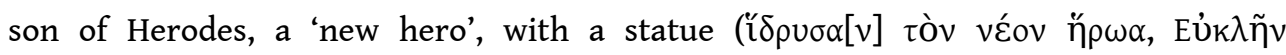
'H $\omega \omega ́ \delta$ o[v]), when Polycharmos (Eukles' son) was archon and priest of Drusus Hypatos

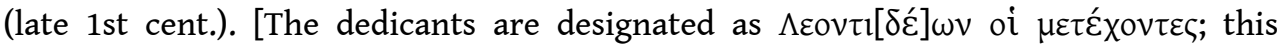
participle also appears in a fragmentary dedication to Claudius from Rhamnous (IG II ${ }^{2}$ 3275 = I.Rhamnous 157); it refers to some sort of association, whose nature must have been apparent to the reader from the location of the statue]. Eukles is known as archon, general, and priest of Apollo in the second half of the 1st cent.; he is an ancestor of Herodes Atticus. After the death of Drusus (9 BCE), the eponymous archon of Athens also served as the priest of Drusus Hypatos. [This is another example of the phenomenon of heroization, studied by C.P. JONES, New Heroes in Antiquity: From Achilles to Antinoos, Cambridge, MA, 2010; for further recent examples, see EBGR 2014, 71 and 2015, 112; see also infra no. 70].

29) J.-M. CARBON, “Minor Notes in I.Iasos 52”, EA 49 (2016), p. 67-69: C. proposes minor restorations to a decree of Iasos granting to Theodoros and his descendants the priesthood of Zeus Idrieus and Hera [Ada?] (ca. 330-320).

30) J.-M. CARBON, “The Festival of the Aloulaia, and the Association of Alouliastai. Notes Concerning the New Inscription from Larisa/Marmarini", Kernos 29 (2016), p. 185-208: See the summary in EBGR 2015, 35. On this important text, see also the remarks of R. BOUCHON, J.-C. DECOURT, and B. HELLY, BE 2016, 291-293.

31) Vacat.

32) A. ChAniotis, "Three Men of Letters in Aphrodisias", in Aphrodisias Papers V, p. 347352 [BE 2017, 514]: Ed. pr. of a posthumous honorific decree for a priest of Hestia Boulaia, who was granted public burial (Aphrodisias, 2nd/1st cent.).

33) A. CHANiotis, “New Epigraphic Finds, 2006-2009”, in Aphrodisias Papers V, p. 333-339 [BE 2017, 513]: C. briefly presents new epigraphic finds from Aphrodisias. 1. A building inscription reports that Diogenes Kokos, priest of Plouton and Kore, provided the funds for the construction of the temple of Plouton and Kore, the cult statues and the interior

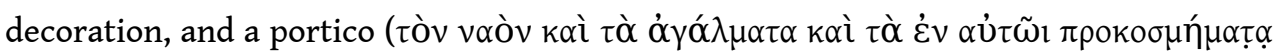

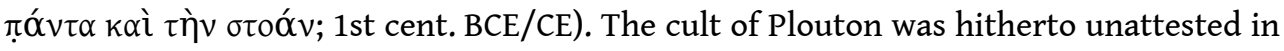
Aphrodisias, but Ploutonia are well-attested in Karia (e.g., in Nysa) and Phrygia (Hierapolis). A sanctuary of Kore is mentioned in a grave monument set up on the street that led from the Sebasteion to the precinct of Kore. 2. An inscription on the lintel of a small temple reports that Eusebes Philopatris, the priest of Zeus Spaloxios

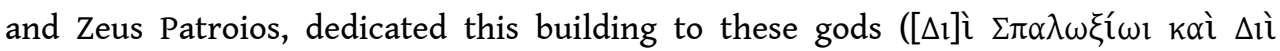

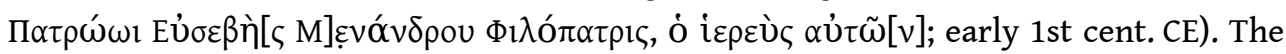

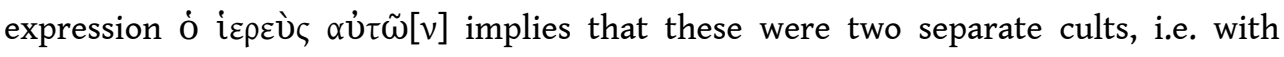
separate cult places and altars [this is yet another example of epithets used to differentiate between two gods that shared similar features but were still regarded as separate; for this phenomenon see EBGR 2012, 82]. The cult of Zeus Patroios was associated with Augustus (IAph2007 12.902). The epithet of Zeus Spaloxios derives from an unattested Anatolian place name (Spaloxa; cf. e.g. Araxa), as the ending -1os implies. His cult in the area of Aphrodisias is known through a dedication made by a freedman (I.Amyzon p. 166 note 27) [it is also mentioned on a coin of Aphrodisias, as Zeus Spaloxos; Spaloxos is known as one of the three Kouretes who came to Karia from Crete 
(Labraundos, Panamaros, and Spaloxos); all three names are connected with place names and epithets of Zeus]. The dedicant was one of the most prominent citizens of Aphrodisias in the early 1st century CE, one of the sponsors of the Sebasteion [a more recent find shows that his full name is Myon Eusebes Philopatris; see A. CHANIOTIS, "Myon, a True Ktistes: A New Inscription from Aphrodisias and its Context", in C.M. DRAYCOTT et al. (eds.), Visual Histories of the Classical World. Essays in Honour of R.R.R. Smith, Turnhout, 2018, p. 449-458].

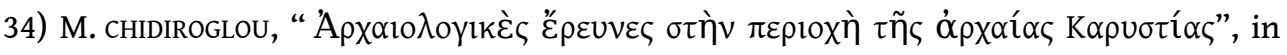

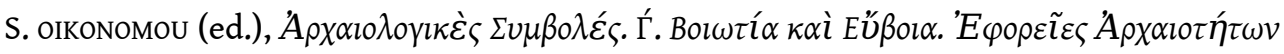

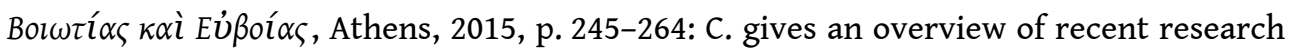
at a sanctuary in Plakari, near Karystos (Euboia) and mentions the discovery of vases

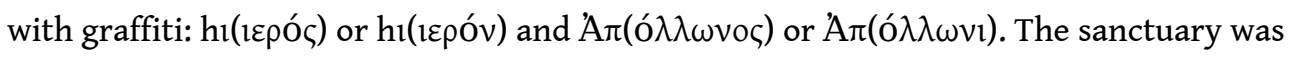
in use from the 10th to the early 3 rd cent.

35) A. CINALI, "Painted and Charcoal Inscriptions from the Territory of Cyrene: Evidence from the Underworld", in R. BENEFIEL and P. KEAGAN (eds.) Inscriptions in the Private Sphere in the Greco-Roman World, Leiden, 2016, p. 181-212: A large tomb in the southern necropolis of Cyrene ('the Carboncini Tomb') has numerous graffiti written with charcoal on the walls (Hellenistic to Late Antique). One of them presents reflections on

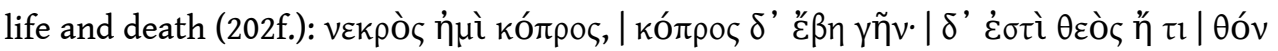

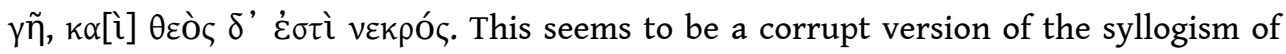

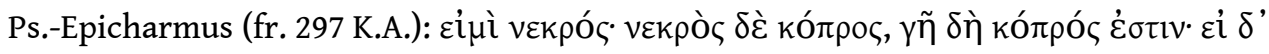

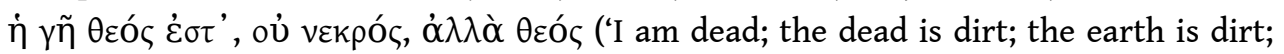
but if the earth is divine, then I am not dead, but a god').

36) T. CORSTEN, "An Inscription from Çavdir in the Burठur Museum and the Persistence of Ancient Place Names”, in H. METIN et alii (eds.), Pisidia Yazıları Hacı Ali Ekinci Armağanı Pisidian Essays in Honour of Hacl Ali Ekinci, Istanbul, 2015, p. 7-11 [BE 2016, 473; SEG LXI 1235]: Ed. pr. of an inscription from Kibyra. A former tenant of the village(?) of Tangara dedicated a temple to Zeus Epekoos (206 CE).

37) T. CORSTEN, "Heidnische Kultorte in der Kibyratis zur Zeit der Christianisierung", in B. BECK-BRANDT, S. LADSTÄTTER, and B. YENER-MARKSTEINER (eds.), Turm und Tor. Siedlungsstrukturen in Lykien und benachbarten Kultlandschaften, Vienna, 2015, p. 93-102 [SEG LXV 1462]: Ed. pr. of a dedication from the area of Kibyra (the village of the Ormeleis, early 3rd cent. CE). Most of the text is now lost, but it is known from a copy of J. Jüthner made in 1897. Under the heading ${ }^{\prime} O \varphi \theta \alpha \lambda \mu o ́ \theta \varepsilon o$, the text reports that the priests of Sozon constructed a temple for the well-being of the Ormeleis and of Annia Aurelia Faustina, the grandniece of the emperor Marcus Aurelius and owner of the land in this area. The gods designated as Ophthalmotheoi may be associated with the belief

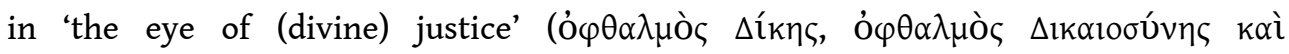
$\Sigma \omega \varphi \rho \circ \sigma$ v́v๘).

149 38) J. CURBERA, "The Curse Tablets of Richard Wünsch Today", in D. BOschung and J.N. BREMMER (eds.), The Materiality of Magic, Leiden, 2015, p. 97-122 [SEG LXV 169-170]: C. provides improved editions of Attic curse tablets originally published by R. Wünsch in IG III App. (nos. 33, 74, 138).

150 39) J. CURBERA, "Five Curse Tablets from the Athenian Kerameikos", ZPE 199 (2016), p. 109-118: C. provides improved editions of five curse tablets from Athens. 1 (SEG XL $267=E B G R$ 1990, 321 I 513, ca. 400-350): The defigens binds to the gods of the 


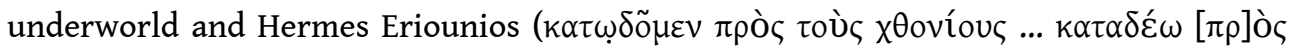

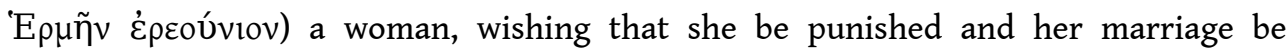

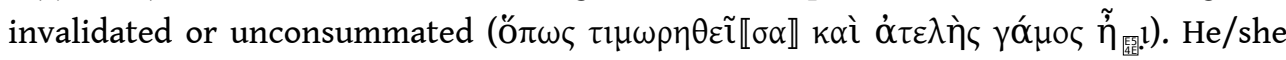
curses her vulva, her insolence, her debauchery, and 'everything belonging to the

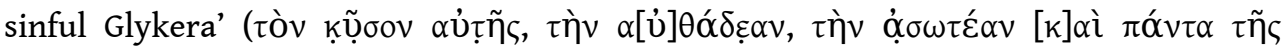

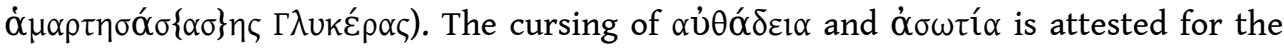
first time in a defixio. 2 (SEG LIV 396, ca. 385-360): The defigens curses ca. 8 people and the workshop of Hermoxenos. 3 (W. PEEK, Inschriften, Ostraka, Fluchtafeln. Kerameikos 3, Berlin, 1941, p. 94f. no.5; ca. 350): This defixio consists of a list of names; at least 40 individuals were cursed. 4 (SEG XL $266=$ EBGR 1990, 321 I 520, late 4th cent.): The

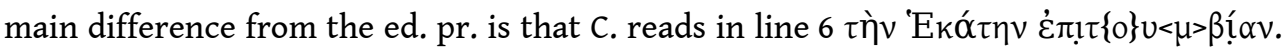
5 (SEG XL $268=$ EBGR 1990, 321 I 518, ca. 350): This defixio is difficult to read. C.

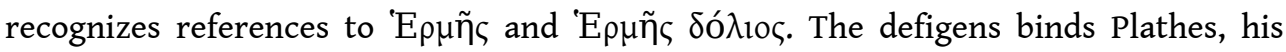
tongue and his hands, as well as several other people.

40) D. DANA, “Notices épigraphiques et onomastiques III", ZPE 198 (2016), p. 145-161: D. republishes a statue group representing the Thracian Rider God and a bear attacking a

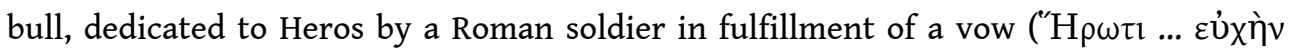

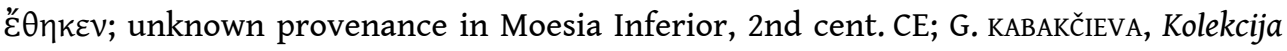
Vasil Božkov, Sofia, 2005, no. 107).

41) D. DANA and M. DANA, "Quelques inscriptions grecques et latines des collections privées de Bulgarie", AWE 15 (2016), p.161-182: R.-D. republish Greek and Latin inscriptions, mostly of unknown provenance (Thrace or Moesia Inferior) in private collections in Bulgaria. Greek inscriptions: 3: Silver kantharos with the representation of

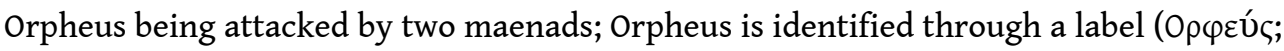
Trakija i drevnijat svjat XV-I v. pr. Hr. Kolekcija Vasil Božkov, Sofia, 2011, p. 79-82 no. 53;

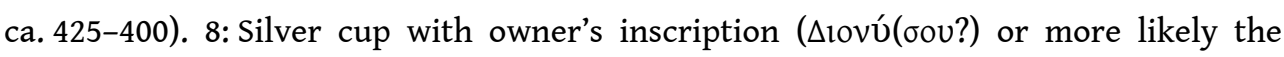
beginning of a theophoric name) followed by a numeral (54) indicating the weight (I. MARAzov, Kolekcija Vasil Božkov, Sofia, 2005, p. 71 no. 62/10; 2nd/1st cent.). 9. Silver goblet with owner's inscription ( $\Delta$ ló $\varsigma$ or the beginning of a theophoric name) followed by a numeral (31) indicating the weight (I. MARAZov, Kolekcija Vasil Božkov, Sofia, 2011, p. 125 no. 90; 2nd/1st cent.) [if the inscriptions on these two silver vases refer to theonyms, they may indicate that the vessels were used to pour libations in honor of Dionysos and Zeus; such inscriptions are very common on clay vases; see A. CHANIOTIS, "The Epigraphy of the Night", in N. PAPAZARKADAS and C. NOREÑA (eds.), From Document to History: Epigraphic Insights into the Greco-Roman World, Leiden, 2019, p. 27f.]. 12. Lower part of a statuette representing Hera seated on a throne, with a lion on her right; an inscription on the base reports that the statue was dedicated by a woman to Hera in

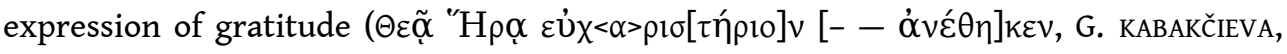
Kolekcija Vasil Božkov, Sofia, 2005, no. 104; Imperial period). 13. Votive relief representing Zeus and Hera offering a libation; Hera is flanked by two lions; the relief was dedicated 'to the goddess' ( $\tau \tilde{n} \theta \varepsilon \tilde{\omega})$, apparently Hera (eastern Thrace?; G. KABAKČIEVA, Kolekcija Vasil Božkov, Sofia, 2005, no. 114; Imperial period). 14. Dedication to Heros (see supra no. 40). 15. Dedicatory relief with a representation of the Thracian

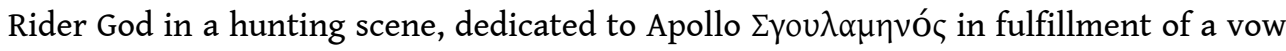

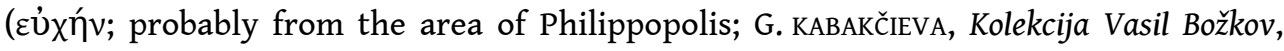
Sofia, 2005, no. 108; 2nd/3rd cent.). Latin inscriptions: 1. Votive relief with a representtaion of Silvanus, a dog, and three Nymphs, dedicated to the Nymphs and 
Silvanus ((D)eabus Silvesstres [sic] et Silvano) by two traders with Greek names (Moesia Inferior; G. KABAKČIEVA, Kolekcija Vasil Božkov, Sofia, 2005, no. 106; Imperial period). 2. Altar dedicated to Iuppiter Optimus Maximus and Juno Regina (Moesia Inferior; G. KABAKČIEVA, Kolekcija Vasil Božkov, Sofia, 2005, no. 113; Imperial period). 3. Marble column dedicated by a veteran to Iuppiter and Juno (unpublished; Moesia Inferior, 3rd cent. CE).

42) N. Dimitrova and K. CLINTON, "The Annual Samothracian Festival Attended by Theoroi", in A. MATTHAIOU and N. PAPAZARKADAS (eds.), 'A $\xi \omega v$. Studies in Honor of Ronald S. Stroud, Athens, 2015, p. 639-648 [BE 2016, 391]: According to the traditional view, the theoroi visited Samothrake for a great annual celebration of the mysteries. D.-C. argue, instead, that the visit took place during the dramatic contest of the Dionysia (cf. IG XII. 4.148 line 19;153, 163; I.Priene 69). The mythical subjects of the works composed by the tragic poet Dymas (IG XII.8.153) and the epic poet Herodes (I.Priene 69), i.e. the deeds of Dardanos and the abduction of Harmonia by Kadmos, may have been related to what was dramatically presented to the initiates. The three consecutive days of initiation mentioned in CIL $\mathrm{I}^{2} 664$ may have been immediately before or after the Dionysia (late spring or early summer). Therefore, D.-C. suggest restoring in IG XII.8.148 lines 11/12

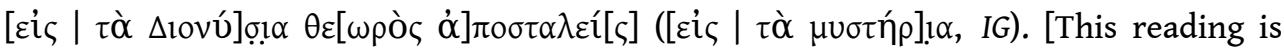
rejected by P. FRÖHLICH, BE 2016, 391, who argues that neither the proclamation of honors during the Dionysia nor the performance of the works of Dymas and Herodes in the theater support the assumption that the visit of the theoroi took place during the Dionysia. It is indeed more probable that a $\theta \varepsilon \omega p i ́ \alpha$ to Samothrake was addressed not to Dionysos, but to the sanctuary's main gods, the Megaloi Theoi; however, a combination of a major celebration of the mysteries and the Dionysia is not impossible].

43) B. DREYER, "Eine Landstadt am Puls der Zeit - Neue Inschriften zum Gymnasion und zum Bad aus Metropolis in Ionien", in P. scholZ and D. WIEGAND (eds.), Das kaiserzeitliche Gymnasion, Berlin, 2015, p. 133-148 [BE 2016, 423; SEG LXV 1052]: In a discussion of the gymnasion of Metropolis in Ionia, D. presents an honorific inscription for an agonothetes who provided the funds for the establishment of new contests (late 1st/

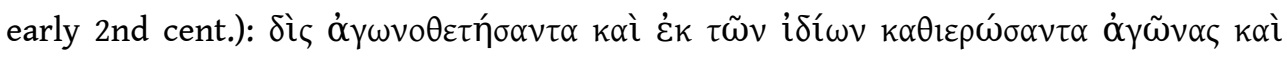
$\theta \varepsilon \omega p i ́ \alpha \varsigma$ [D. ROUSSET, BE 2016, 423 and H. PLEKET, SEG LXV 1052, points out that $\theta \varepsilon \omega p i ́ \alpha 1$ here means 'spectacles' and not 'embassies' (as translated by D.)].

44) B. DREYER, "Leben und Sterben in Metropolis (Ionien)", in S. NAWRACALA and R. NAWRACALA (eds.), Polymatheia. Festschrift für Hartmut Matthäus anläßlich seines 65. Geburtstages, Aachen, 2015, p. 87-114 [SEG LXV 1053, 1054]: Ed. pr. of inscriptions from Metropolis. The most interesting text commemorates the dedication by a councilor and

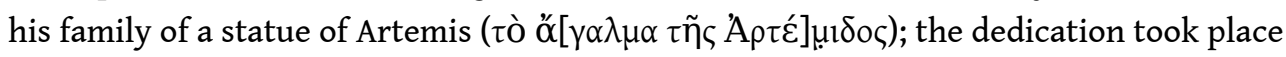

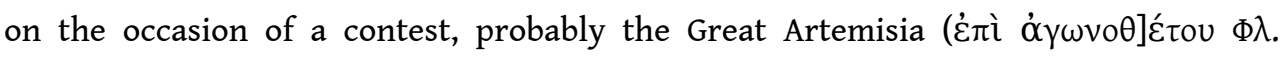

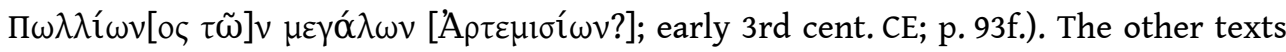
are an altar for Zeus Soter (1st cent.; p. 92f.); a dedication to Augustus (1st cent. CE; p. 95f.); and an altar dedicated to Sabina by a priestess (p. 92).

45) A. ERDOĞAN, “Tripolis Roma Caddesi 2007-2009 Kazi Çalişmalari Ön Raporu”, Arkeoloji Dergisi 19 (2014), p. 41-125 [SEG LXV 1098]: In his report on recent excavations in Tripolis, E. mentions an inscribed plaque [read from the ph. by T. Corsten, SEG LXV 1098 , and recognized as an honorific inscription. The text of lines 4-7 probably reveals

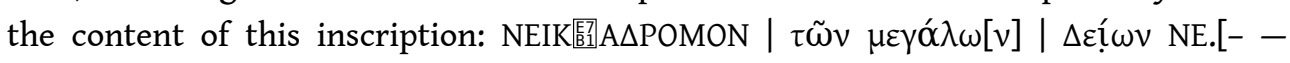


-]|. $\alpha \rho \alpha \imath \omega v$ [- - - ]. The accusative (line 4) suggests the dedication of an honorific statue, most likely for a victor at a local agonistic festival in honor of Zeus (lines $5 \mathrm{f}$.:

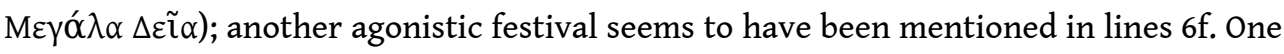

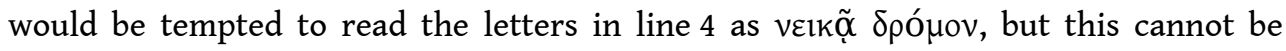
reconciled with the following genitive ( $\tau \tilde{\omega} \nu \mu \varepsilon \gamma \alpha \dot{\alpha} \lambda \omega[v] \mid \Delta \varepsilon i ̣ v)$. We may have the unattested word $v \varepsilon เ \kappa \alpha \delta \rho o ́ \mu о \varsigma$ ('victor in race'); cf. the common personal name

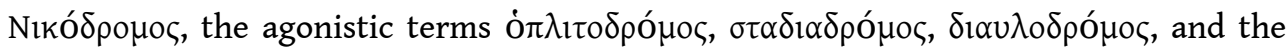

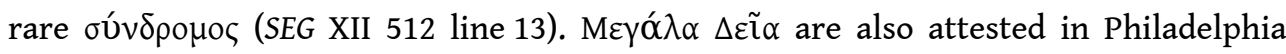
(TAM V.3.1511)].

46) J.M. FREY and T.E. GREGORY, "Old Excavations, New Interpretations: The 2008-2013 Seasons of the Ohio State University Excavations at Isthmia”, Hesperia 85 (2016), p. 437-

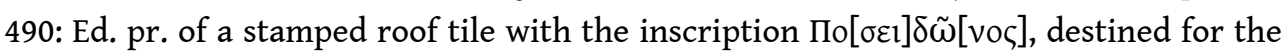
temple of Poseidon (undated; p. 474 no. 10) [probably early Imperial period].

47) J.L. FRIEND, "The Nemesia in Lycurgan Athens", in J. BODEL, and N. DIMITROVA (eds.), Ancient Documents and their Contexts, Leiden, 2015, p. 98-110 [BE 2016, 169; SEG LXV 33]: F. argues that the torch-race mentioned in an inscription from Rhamnous (Petrakos,

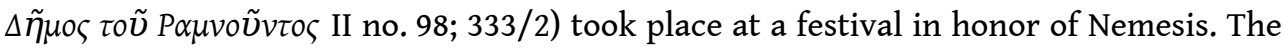
Nemesia, explicitly attested in the 3rd and 2nd cent., must have existed in Lycurgan Athens in connection with a commemoration of Nemesis' punishment of Persian hubris in the Battle of Marathon (cf. Paus. I, 33, 2-3). This would explain the participation of the ephebes. The festival, consisting of athletic contests and a torch-race, was discontinued after Athens' defeat in the Lamian War and revived in the $3 \mathrm{rd}$ cent.

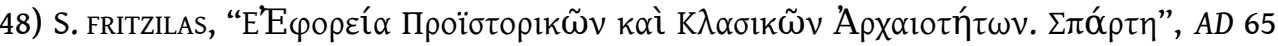
B1 (2010) [2016], p. 445-447 [SEG LXIV 243]: A tile for a building dedicated to Apollo was

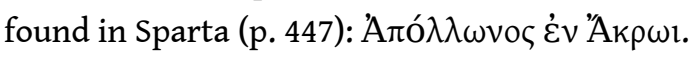

160 49) P.-L. GATIER and J. SEIGNE, "Un exceptionnel document d'architecture à Gerasa (Jérash, Jordanie)", Syria 92 (2015), p. 263-277 [BE 2016, 547; SEG LXV 1795]: Ed. pr. of an honorific epigram, inscribed within a wreath in relief on a keystone block (Gerasa, 1st cent. CE). The epigram praises Demetrios, probably to be identified with a priest of Augustus, for constructing a stoa in the sanctuary of Zeus. He was honored with a

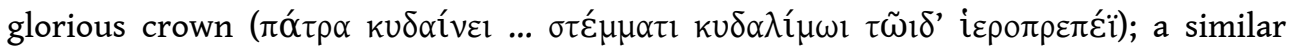
expression can be restored in SEG LI 1929 [the characterization of the wreath as

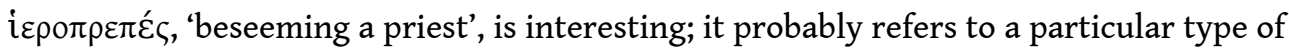
crown; for this phenomenon, see A. CHANIOTIS, "Theatre Rituals", in P. WILSON (ed.), The Greek Theatre and Festivals. Documentary Studies, Oxford, 2007, p. 58].

161 50) E. GOSE and F. SCHOBER, "Ergebnisse einer topographischen Reise durch Phokis. Appendix I: Inschriften”, MDAI(A) 131/132 (2016/2017), p. 323-370: The A. present the results of a survey in Phokis. The epigraphic appendix, edited by K. HALLOF, includes new inscriptions: a dedication to Eileithyia from Elateia ( 3 , undated) and a fragmentary dedication from Panopeus/Phanoteus (SEG XLVII 549; p. 365).

51) A. GRECO and A. BETTO, "Christos Effendi: Archaeological Studies on the Acropolis of Phaistos: from Minoan to Post-Palatial Phasa - an INSTAP Project", in AEK 3 (2013) [2015], p. 483-494: A terracotta votive with the letters [A] $\theta \alpha v \alpha$ 朕 [- - ], the name of Athena, was found on the acropolis of Phaistos (ca. 6th/5th cent; p. 487). 


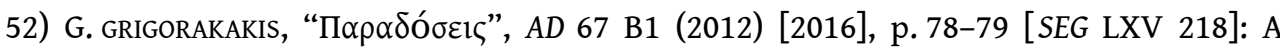
bronze statuette of Dionysos riding a mule, a chance find in South Kynouria, was dedicated to Apollo Tyritas (6th cent.).

53) F. Guizzi and M. NocitA, "Novità epigraphiche dà Hierapolis di Frigia", Scienze dell'Antichità 21 (2015.1), p. 31-38 [BE 2016, 476; SEG LXV 1249-1252]: Ed. pr. of four dedications from the sanctuary of Plouton in Hierapolis in Phrygia. 1. An altar was

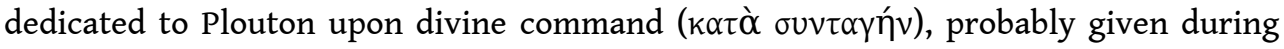

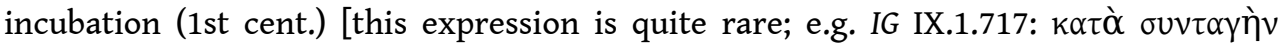

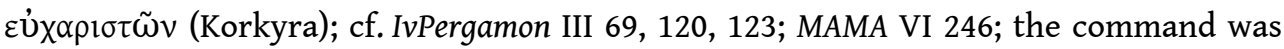
given in a dream, but not necessarily during incubation]. 2-3. Two altars were

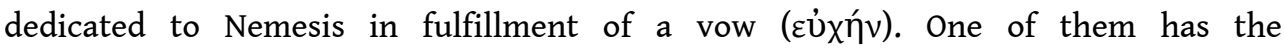
representation of an ear [an indication that Nemesis was غ̇ $\pi$ ńкоо; cf. the dedication of gladiators from Aphrodisias (SEG LVI 1191)]. 4. The addressee of another dedication in

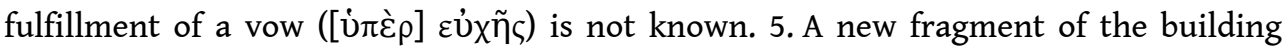
inscription of the Ploutonion, reporting the dedication of the vaulted entrance ( $\psi \alpha \lambda \mathbf{i}^{\mathrm{c}}$ ) to Plouton and Kore [cf. EBGR 2014, 41]. 6. A dedication made by the priest of Plouton,

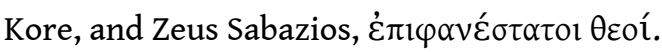

54) H. GÜNEY, "New Inscriptions from the Choria Considiana: Çalçak Roman Necropolis", AS 66 (2016), p. 125-139 [BE 2017, 558]: Ed. pr. of inscriptions from an imperial estate at Choria Considiana (northwestern Galatia). We note two grave epigrams (2nd cent. CE) that express the idea that the death of two young women was caused by envious fate:

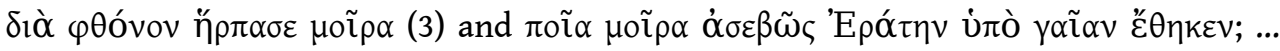

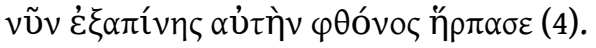

55) W. GÜNTHER and S. PRIGNITZ, "Ein neuer Jahresbericht über Baumaßnahmen am Tempel des Apollon von Didyma", Chiron 46 (2016), p. 157-175: Ed. pr. of an account of building work carried out in the temple of Apollo in Didyma (ca. 175-170). The account mentions the number of marble and limestone blocks transported and used for the construction of the temple by 20 slaves under the supervision of Artemon

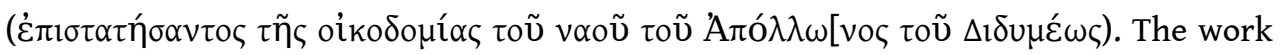

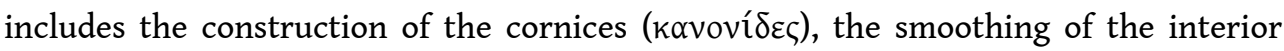

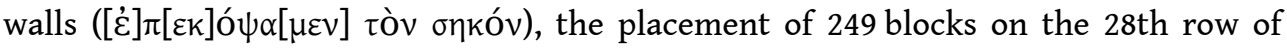
blocks, and the construction of an altar of Basileia (Aphrodite?) outside the precinct ( $\dot{\varepsilon} \gamma$ $\left.\chi \omega \omega_{p \alpha l}\right)$. The construction work lasted 20 days, from the 10th to the 30th Thargelion. This text provides valuable insights into the building process of a temple.

56) W. GÜNTHER and V. SICHELSCHMIDT, "Ein Inschriftenfragment aus Didyma", MDAI(I) 65 (2015), p. 281-291: Ed. pr. of a dedication to Apollo as a dekate, found in Didyma (ca. 500). The fragment probably belonged to a reclining figure.

168 57) P. HAMON, "Études d'épigraphie thasienne, IV. Les magistrats thasiens du IV s. av. J.C. et le royaume de Macédoine", BCH 139/140 (2015/2016), p. 68-125 [BE 2017, 424; SEG LXV 733, 735-737]: H. studies the structure of the lists of archontes and theoroi in Thasos and reconstructs the process of inscribing the names of magistrates. In this context, he presents a new edition of the first lines of a document recording the lease of real estate belonging to Herakles (IG XII Suppl. 353; SEG LV 972), which he dates to 328 BCE (p. 107112). He also republishes a dedication to a King Philip Soter (Recherches - Thasos I 405) and presents the ed. pr. of an altar for the cult of a King Philip; he identifies the recipient of this cult with Philip II and dates these inscriptions to the late 4 th cent. 
169 58) P. HAMON, "La Moire à Apollonia”, Chiron 46 (2016), p. 265-284: H. presents an improved edition of two consolatory decrees from Apollonia Mordiaon (118/19 CE; SEG LXII 1124) [cf. EBGR 2012, 102]. The premature deaths of Ammia (A) and

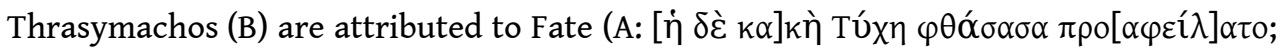

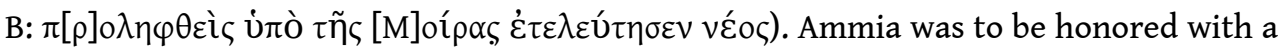
crown by the people during the funeral.

59) K. HARTER-UIBOPUU, “Hermogenes und die $\pi \rho o ́ \beta \alpha \tau \alpha$ des Kaikos (TAM V 1, 464)", Philia 2 (2016), p. 63-71 [BE 2017, 484]: H.-U. discusses the legal background of a 'confession inscription' from Ayazviran in Lydia (TAM V.1.464, 3rd cent.) that reports the

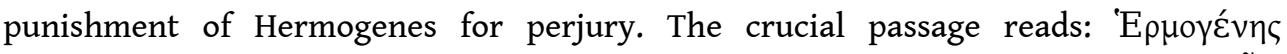

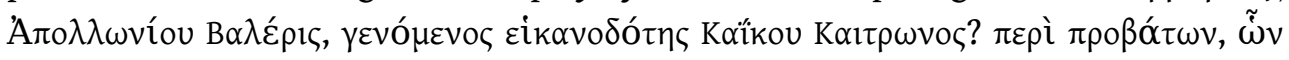

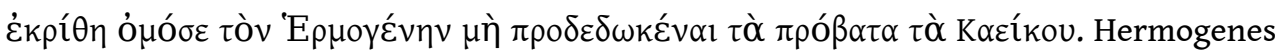
had some animals belonging to Kaikos, and he was obliged to return them to him; when he failed to fulfill his obligation, Kaikos pursued a lawsuit and Hermogenes was 'obliged

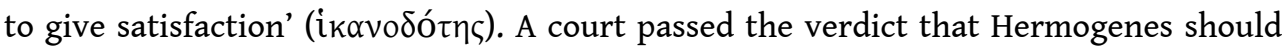
take an oath that he had not abandoned or given away the animals. After Hermogenes had sworn an exculpatory oath, he met with misfortunes that were interpreted as

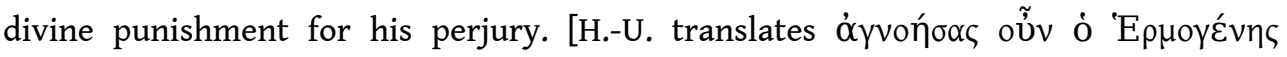

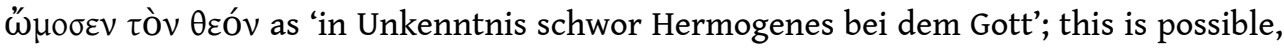

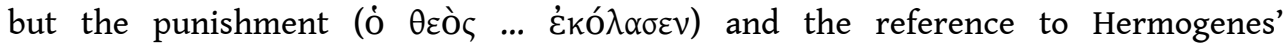

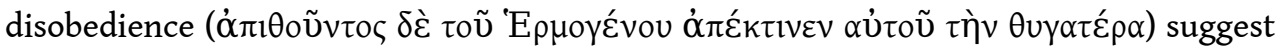

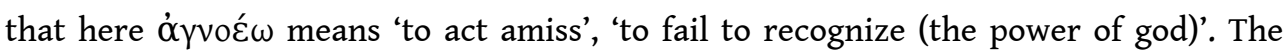
verb is used in this sense in BIWK 10: 'Stratonikos, son of Euangelos, cut down an oak (of

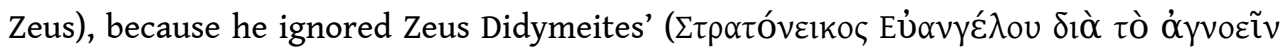

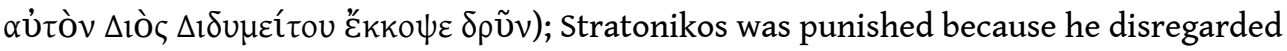

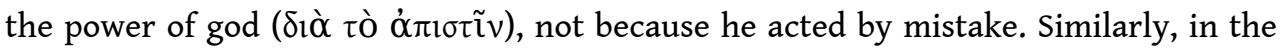
case of Hermogenes, $\dot{\alpha} \gamma v o n \sigma \alpha \varsigma$ seems to explain the severe punishment (the death of

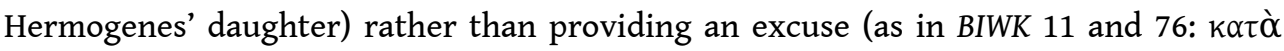
ö үvorav, 'unknowingly, by mistake')].

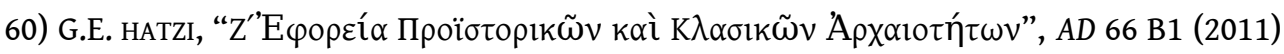
[2016], p. 303-321 [SEG LXV 302-305]: Several inscriptions were found in a sanctuary at the Kronion in Olympia, which $\mathrm{H}$. proposes to identify as a sanctuary of Eileithyia. One of the inscriptions, on a mirror, names this goddess (p. 312; undated) [for a second mirror see infra no. 61]. The content of the other inscriptions is not revealed. The finds from this sanctuary also include a stamped tile that names Zeus (p. 311).

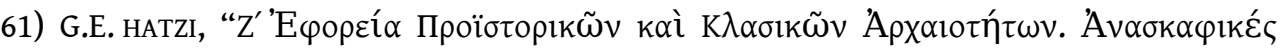

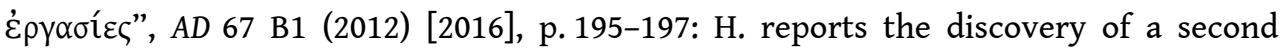
mirror dedicated to Eileithyia in Olympia (p. 197; cf. supra no. 60).

62) O. HENRY and D. AUBRIET, "Le territoire de Mylasa et le serment d'Olympichos : autour d'une nouvelle inscription découverte au sanctuaire de Zeus Labraundos en Carie", CRAI (2015), p. 673-702 [BE 2017, 499]; SEG LXV 996]: Ed. pr. of a letter sent by Olympichos, Seleucid general in Karia, to Mylasa (Labraunda, ca. 242-227). Olympichos mentions his earlier oath to Mylasa, with which he promised to respect the city's freedom and the inviolability of Mylasa's sanctuaries (cf. I.Labraunda 3); this asylia was possibly granted by Seleukos II when Mylasa was liberated (after $246 \mathrm{BCE}$ ). The new text shows that Olympichos occupied a fortress under the pretext of Mylasa still owing a kind of "crown 
tax' ('I would occupy it until I recovered for the king the money owed for the crown') [republished by N. CARLESS UNWIN and O. HENRY, "A New Olympichos Inscription from Labraunda: I.Labraunda 137”, EA 49 (2016), p. 27-45].

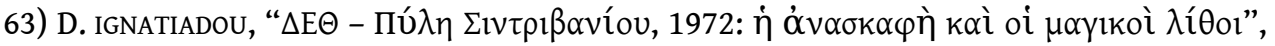
AEMTh 25 (2011) [2015], p. 297-308 [SEG LXV 536]: I. presents two amulets of green jasper with red dots (heliotropium) found in the area of the eastern cemetery of Thessalonike (ca.3rd cent.CE; p. 298-301). One amulet is uniscribed; it has a representation of Bes Pantheos. The other amulet is framed by a gold pendant. On the obverse, a scarab is encircled by an ouroborus; a variant of the tetragrammaton $(\mathrm{H} \Omega \mathrm{EH}$, Yahveh) is engraved between the legs of the scarab; the inscription on the reverse (IAI $\triangle A \Theta I A I|I H \Sigma H \Phi I \Delta I| \Omega K N H N I \Omega$ ) is a corrupt variant of a known vox magica, with a

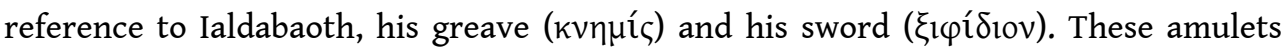
may have belonged to a Jewish woman [cf. infra no. 128].

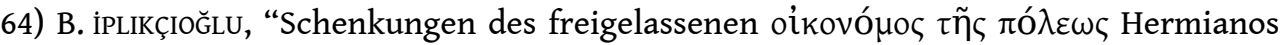
an die Stadt Korydalla (Südost-Lykien)", AAWW 149 (2014), p. 5-23 [BE 2016, 467; SEG LXV 1384]: Ed. pr. of an inscription from Korydalla (ca. 209-211). The steward of the

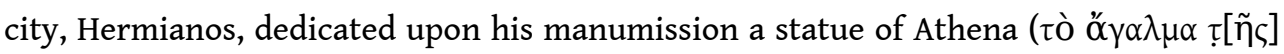

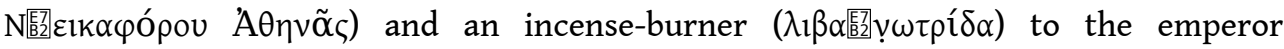
Septimius Severus, his sons Caracalla and Geta, and Julia Domna.

65) B. IPLIKCıoĞLU, "Heraklit von Rhodiapolis, ein gefeierter Arzt der trajanischen Zeit", in J. FISCHER (ed.), Der Beitrag Kleinasiens zur Kultur/ und Geistesgeschichte der griechischrömischen Antike, Vienna, 2014, p. 231-245 [BE 2015, 651; SEG LXIV 1410]: Ed. pr. of an honorific inscription for the famous physician, philosopher, and poet Herakleitos (early 2nd cent.; cf. TAM II 906 and 910), who served as priest of Asklepios and Hygieia $\theta \varepsilon$ rò $\sigma \omega \tau \tilde{\eta} \rho \varepsilon \zeta$. Herakleitos had provided the funds for the construction of a temple of Asklepios and Hygieia, their cult statues and the decoration of the temple

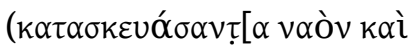

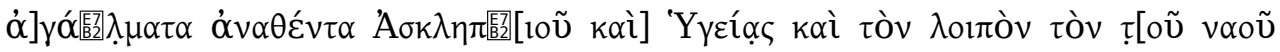

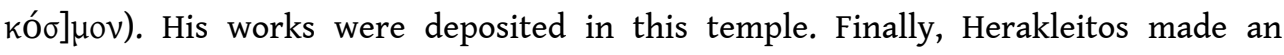

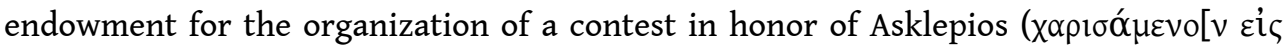

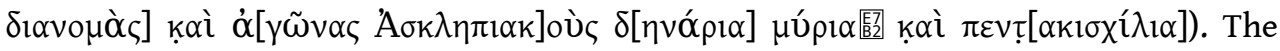

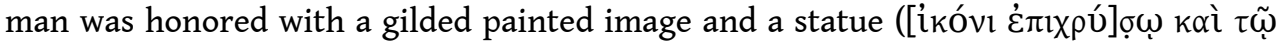

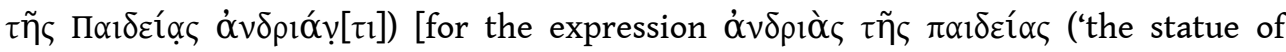
erudition', i.e. a statue showing Herakleitos as a man of letters) and for analogous expressions characterizing specific types of statues ( $\dot{\alpha} v \delta \rho 1 \alpha \alpha_{\varsigma} \tau \tilde{\eta} \varsigma \pi \alpha 1 \delta \varepsilon i ́ \alpha \varsigma, \dot{\alpha} \rho \varepsilon \tau \tilde{\eta} \varsigma$

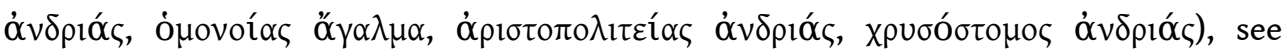
A. WILHELM, "Zu einem Beschlusse von Thiasiten aus Kallatis, betreffend Beiträge zum Baue eines Tempels des Dionysos", AAWW (1928), 136f.; L. ROBERT, "Inscriptions d'Aphrodisias", AC 35 (1966), p. 398f.; A. CHANIOTIS, supra no. 32, p. 350f.].

66) S. ISAGER, "On a List of Priests: From the Son of Poseidon to Members of the Elite in Late Hellenistic Halikarnassos", in J. FEJFER, M. MOLTESEN, and A. RATHJE (eds.), Tradition: Transmission of Culture in the Ancient World (Acta Hyperborea 14), Copenhagen, 2015, p. 131-148 [BE 2016, 453; SEG LXV 956]: Ed. pr. of a new fragment of the famous list of the priests of Poseidon Isthmios from Halikarnassos (ca. 100; cf. Syll. ${ }^{3}$ 1020). The new fragment belongs to the left column but does not join the main fragment (Syll. $\left.{ }^{3} 1020\right)$. It contains the names of 18 priests who served for life, as well as the number of years they 
remained in office (from 1 to 64 , a total of 324 years). The list traces the priests back to the arrival of settlers from Troizen under the patronage of Apollo and Poseidon. The total time served by the priests can be estimated to at least 827 years. The list, allegedly a copy of an ancient stele, is an example of the 'invention of traditions' in the Hellenistic period.

67) S. ISAGER and P. PEDERSEN, "Om arbejdet med indskrifterne fra Halikarnassos: et upublicetet aeresdekret som eksempel", in Logos - klassikerforeningens medlemsblad (February 2015), p. 40-45 [SEG LXV 954]: Ed. pr. of an honorary decree for a man from Alabanda (Halikarnassos, ca. 300-254). The man was granted access to the council and the assembly immediately after the sacred matters and the decree was set up in the sanctuary of Apollo (on the Zephyrion).

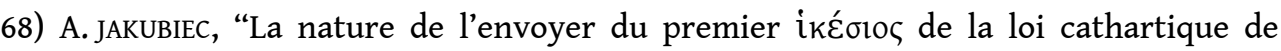
Cyrène (SEG IX, 72, 111-121)", ZPE 197 (2016), p. 96-100: J. reviews the interpretations that have been proposed with regard to a passage in the cathartic law of Cyrene (SEG IX

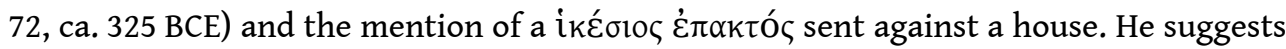
that this spirit was sent by a deceased individual my means of a magic ritual; the text reveals the anxiety towards magic.

180 69) A. JAKUBIEC, "Qui faut-il accueillir selon la colonne B de la loi sacrée de Sélinonte

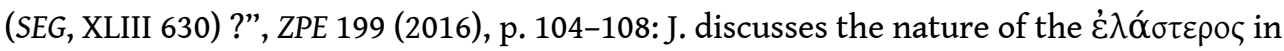
the prescriptions concerning purification from Selinous (SEG XLII 630) and argues that the text [which he takes to be a public law of the Selinountians] stipulates that a volunteer should offer hospitality to a man pursued by an impure spirit, in order to put a stop to its harmful actions. [On this text see various contributions in A. IANUCCI, F. MUCCIOLI, and M. ZACCARINI (eds.), La città inquieta. Selinunte tra lex sacra e defixiones, Milano/Udine, 2015, which I could not summarize in this issue].

181 70) C.P. JoNES, “An Altar for a New Hero", ZPE 199 (2016), p. 83-86: J. republishes and comments on an inscription written on a funerary altar (Telmessos or Tlos, 1st/2nd cent.; SEG LXI 1257; EBGR 2015, 112). He recognizes in this text the establishment by Neoptolemos of the heroic cult for his father ( $\pi \alpha \tau \rho \grave{~ \eta े ~} \rho \omega \mathrm{l})$. The cult regulation stipulates: 'Every year among the tombs Neoptolemos or the rent-collector for the estate will sacrifice a yearling wether-goat worth fifteen drachmas and a cake, burning

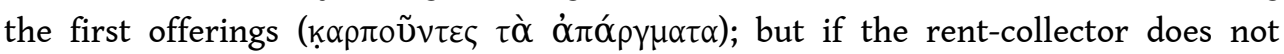
sacrifice, he will be guilty of sacrilege to the gods below earth'.

71) S. КАсZко, Archaic and Classical Attic Dedicatory Epigrams: An Epigraphic, Literary and Linguistic Commentary, Berlin, 2016 [BE 2017, 171]: K. presents critical editions and exhaustive commentaries of 141 dedicatory epigrams from Athens (6th-4th cent.), concerning public and private dedications from the Acropolis (1-116) and other locations (117-141). She discusses the poetic language, epithets of deities, dedicatory

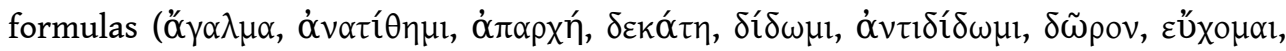

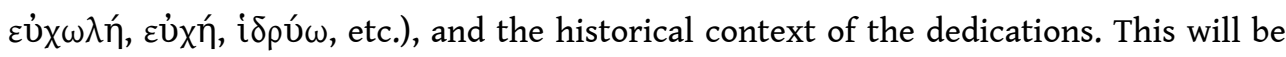
an indispensable work of reference for the study of Athenian religion and the religious mentality behind dedications.

183 72) M. KADIOĞLU, Das Gerontikon von Nysa am Mäander, Darmstadt, 2014: The publication of the building known as the 'Gerontikon' in Nysa includes a survey of the inscriptions found in or associated with this building. K. and W. BLÜMEL (p. 93 no. 118 Y10, ca. 148 CE) present an ineditum, the dedication of an altar and an incense-burner ( $\tau$ ò $[v] \beta \omega \mu[\grave{o}] v$ 


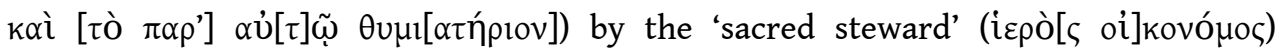
[probably a public slave who served as the oikonomos of the hiera gerousia; for a similar dedication by another public steward see supra no. 64].

73) Y. KALLIONTZIS, "La date de la première célébration des Amphiareia-Romaia d'Oropos", REG 129 (2016), p. 85-105 [BE 2017, 29]: K. republishes the list of victors at the first Amphiareia kai Rhomaia (I.Oropos 521). It is generally believed that the association of Dea Roma with the contest for Amphiaraos postdates Sulla's victory in the First Mithridatic War $(86 \mathrm{BCE})$. K. infers from the presence of a man designated as

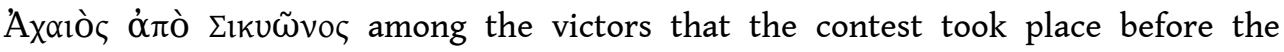

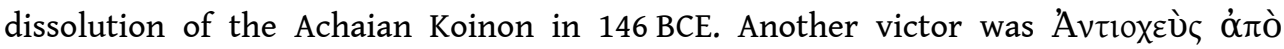

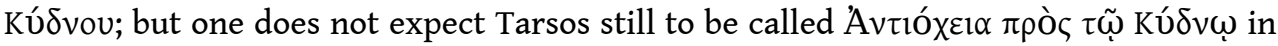

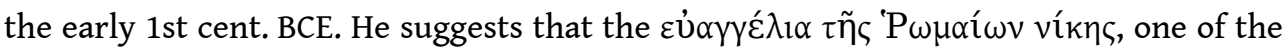
disciplines in which encomiasts competed, refers to the victory of Metellus over Andriskos in $148 \mathrm{BCE}$. The reorganization of the Amphiareia as a joint celebration for Amphiaraos and Dea Roma must have taken place between the victory over Andriskos (148 BCE) and the victory over the Achaians (146 BCE) [see the objections of D. KNOEPFLER, BE 2017, 265].

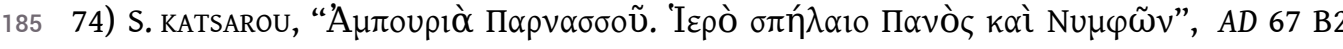
(2012) [2016], p. 818-822: K. reports on the excavation of a cult cave on Mt. Parnassos and presents the dedication to Pan and the Nymphs that we mention in EBGR 2013, 59.

75) C.M. KEesLing, "Solon's Property Classes on the Athenian Acropolis? A Reconsideration of IG I ${ }^{3} 831$ and Ath. Pol. 7.4", in K. DALY and L.A. RICCARDI (eds.), Cities Called Athens: Studies Honoring John McK. Camp II, Lewisburg, 2015, p. 115-135 [BE 2016, 152; SEG LXV 56]: K. proposes a new restoration of a dedicatory epigram for Athena inscribed on a marble basin (IG I3 831. DAA 372. CEG 269; Athens, ca. 480-470). In line 2,

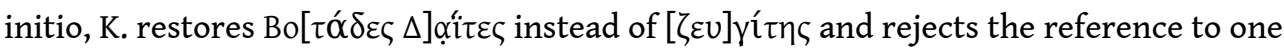
of the Solonian property classes. The basin was not a perirrhanterion but the support of a bronze bowl without a foot. This bronze vessel may have been the prize at a funeral contest, dedicated by a victorious athlete from the deme of Boutadai.

76) A. Kizil, P. brun, L. Capdetrey, R. Descat, P. fröhlich, and K. KonuK, "Pidasa et Asandros : une nouvelle inscription (321/0)", REA 117 (2015), p. 371-409 [BE 2016, 268 and 438]: Ed. pr. of a decree of Pidasa honoring officers of the satrap of Karia Asandros $(321 / 20)$ [corrected to $322 / 21$ by D. ROUSSET, BE 2016, 483 and W. BLÜMEL, supra no. 21 bis]. The three men took care of the public finances and returned to the city bowls

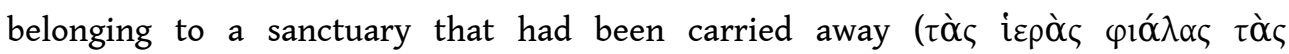
$\dot{\alpha} \pi\left[\left[\alpha \chi \theta \varepsilon i ́ \sigma \alpha \varsigma\right.\right.$ ?] $\dot{\alpha} v \varepsilon \varepsilon_{\sigma \omega l \sigma \alpha v)}$ [D. ROUSSET, BE 2016, 483, suggests that the bowls had been

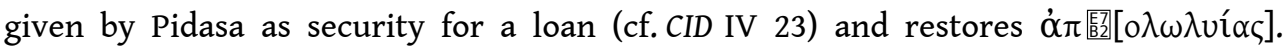
W. BLÜMEL, supra no. 21 bis, suspects that these valuable objects had been carried away

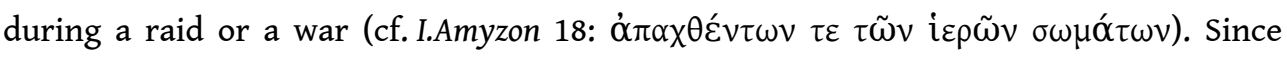
there is no reference to military events in the decree, but rather a reference to the public finances, Rousset's suggestion is more plausible. A similar incident is described in the honorary decree for Protogenes in Olbia; when the city was unable to repay a loan, the 'sacred cups' given as a pledge were carried away to be melted; Protogenes repaid the loan and returned the objects to the city (IOSPE I $\mathrm{I}^{2} 32$ lines 13-18: $\tau \tilde{\omega} v \tau \varepsilon$

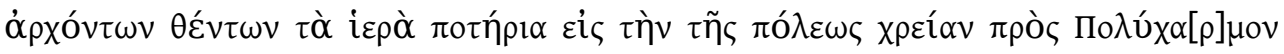

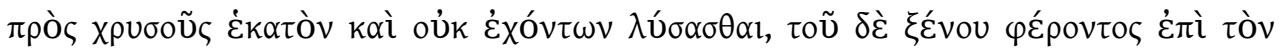




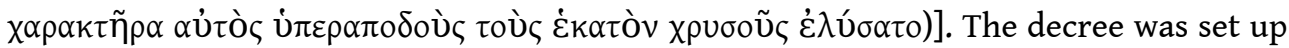
in the sanctuary of Toubassis, an otherwise unattested god with an Anatolian name.

77) C. KRITZAS and S. PRIGNITZ, "A Building Inscription from Epidauros: IG IV ${ }^{2} 1,114$, SEG XLI 298, IG IV ${ }^{2}$ 1, 110", AE 155 (2016), p. 1-41 [BE 2017, 126]: The A. recognize that three fragments from Epidauros, published separately (IG IV 2 .1.114, SEG XLI 298, and IG IV2. 1.110), are parts of the same stele. They present a new edition with exhaustive commentary. The text is an account of the hiaromnamones of the sanctuary of Asklepios, listing revenues (possibly including fines for bad workmanship or delays) and expenses during the priesthoods of Aristolas and Damophilos (ca. 325-300). The money was used for $k \lambda \tilde{i} v \alpha_{l}$ (couches) in the $k \lambda \varepsilon l \sigma i \alpha$ (a ceremonial dining hall, probably to be identified with the 'Multi-purpose Building', previously known as the 'Gymnasion'), for building materials (poros blocks and timber) and their transportation to the sanctuary, and for the services of a scribe.

78) E. LAFLI and H. BRU, “Inscriptions gréco-romaines d'Anatolie IV", DHA 41.2 (2015), p. 216-224 [BE 2016, 511]: Ed. pr. of an honorific inscription for Severus Alexander from Tarsos (225 CE); his statue was dedicated to Athena. For an improved edition, see infra nos. 113 and 137.

190 79) E. LAFLI and H. BRU, "Inscriptions gréco-romaines d'Anatolie V", DHA 42.2 (2016), p. 224-239 [BE 2017, 441]: Ed. pr. of inscriptions from various places in Asia Minor: 1: Honorific inscription for M. Aurelius Attinas, descendant of agonothetai, who also served himself as an agonothetes (Smyrna, 3rd cent. CE). 3: Honorific inscription for the

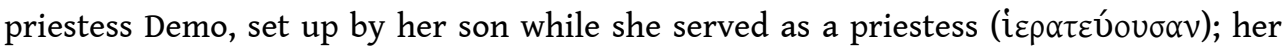
statue, dedicated to the gods, was made by Nikomachos of Kos [Der neue Overbeck nos. 3338-3339] (Halikarnassos, early 2nd cent.). 4: A dedication to an anonymous god:

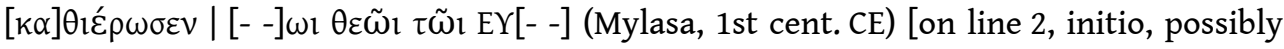

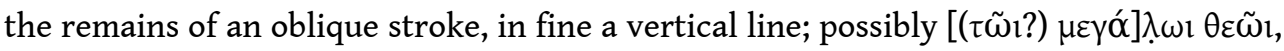

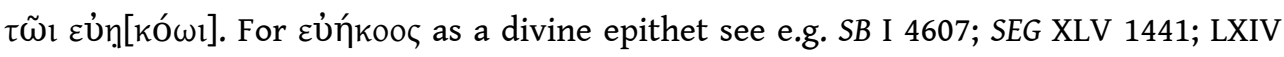
2212]. 7: The torso of a colossal statue from Gerga Kome (Karia), seen by G. Cousin in 1900 , now in the Museum of Izmir, is inscribed with the name of the local god Gergas

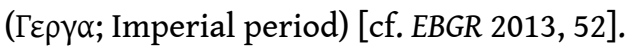

191 80) A. ŁAJTAR, "Another Greek Inscription from Novae (Lower Moesia) Associated with pastus militum", in A. тномAs (ed.), Ad fines Imperii Romani. Studia Thaddaeo Sarnowski septuagenario ab amicis collegis discipulisque dedicata, Warsaw, 2015, p. 277-288 [SEG LXV 572]: Ed. pr. of a metrical dedication to Apollo inscribed on a statue base (Novae,

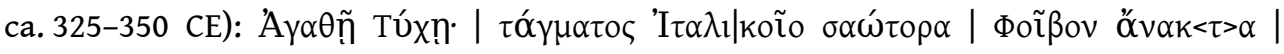

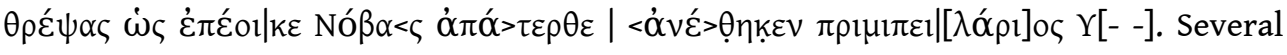
other inscriptions from the principia of the legio I Italica commemorate the dedication of statues by primipilarii after the successful completion of their task to transport supplies to Novae (ca. 300-450) [cf. EBGR 2014, 81; SEG LXIII 535/536]. The cult of Apollo has already been attested in Novae.

192 81) A. LA MARCA, "Lo spazio del sacro a Kyme", Arkeoloji ve Sanat 148 (2015), p. 87-98: The A. presents an unpublished honorific inscription from Kyme (Imperial period; p. 93): a group of mystai dedicated a statue of an imperial procurator, their benefactor. The

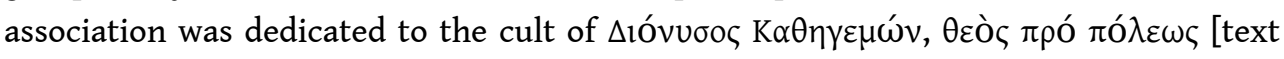
read from the ph. by T. CORSTEN, SEG LXV 1101. For similar cult associations of Dionysos

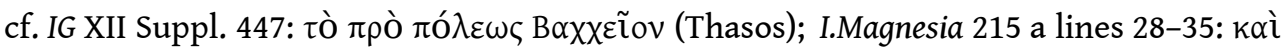




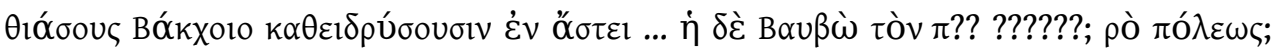

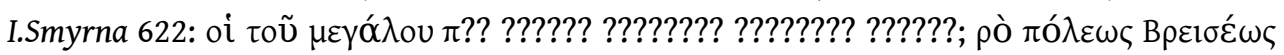

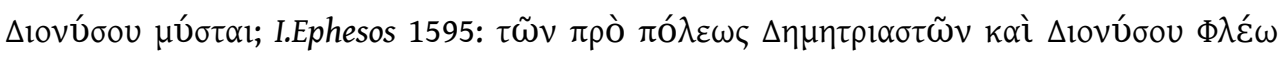
$\mu \nu \sigma \tau \tilde{\omega} \nu$. The cult of Dionysos $\pi \rho o ̀ ~ \pi o ́ \lambda \varepsilon \omega \varsigma$ (an ambiguous expression denoting both protection of the city and an extra-urban sanctuary) is well attested; see SEG XXVI 943 (Thera); I.Ephesos 1267; I.Smyrna 730].

82) N. LANÉRÈS and G. GRIGORAKIS, "1. Une découverte récente: un haltère pour les 'Maleateia' ou Sparte à la conquête de sa côte orientale. 2. L'haltère de Tîron et l'expansion de Sparte sur le territoire de Prasiai (Cynourie du sud)", REG 128 (2015), p. 647-658 [BE 2017, 220; SEG LXV 216]: Ed. pr. of a jumping weight found in the sanctuary of Apollo Maleatas in Kynouria (late 7th/early 6th cent.); it is inscribed with the name of the dedicant, Tiron. He may have dedicated the object after a victory at the Maleateia (cf. IG V.1.213).

83) P. LIDDELL and P. LOW, "An Honorific gnome of the Koinon of the Phrikyladai: A New Inscription from Liverpool”, ABSA 110 (2015), p. 263-284 [BE 2016, 415; SEG LXV 1028]: Ed. pr. of a decree of the koinon of the $\Phi$ pıк $\lambda \alpha \delta^{\delta} \alpha \iota$ in Erythrai in honor of three oi $v \tilde{\omega} v \alpha 1$; L.-L. suggest that they were collectors of tax imposed on wine producers [but D. ROUSSET, $B E 2016,415$, argues that the oi $v \tilde{\omega} v \alpha$ l were assigned the duty to purchase and distribute wine to the members of the koinon; two boards of three wine purchasers served during a year, one per semester. This duty was probably connected with celebrations or banquets]. The decree is dated with reference to eponymous hieropoioi (of Erythrai or of the koinon?).

84) H. LOTZ and A. RUPP, "Ein aussergewöhnlicher Grabfluch: Grabinschrift des Demetrios Makron aus Neapolis (Karien)”, EA 49 (2016), p. 73-84 [BE 2017, 494]: Ed. pr. of an epitaph from Neapolis in Karia(1st/2nd cent.), known from a drawing made by W. Reichel in 1893, now in the Academy in Vienna. A rhetorically elaborate curse threatens any violator of the grave with unusual forms of punishment: $\tau o v i \tau \omega l[\mu \eta \dot{\tau}] \varepsilon$

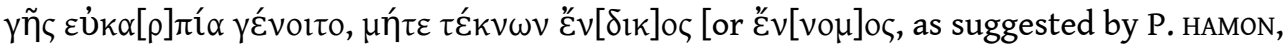

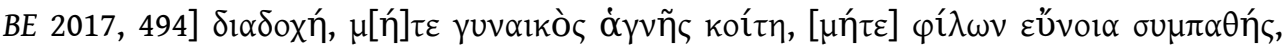

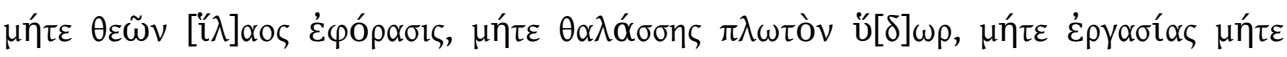
$[\sigma \omega ́] \varphi \rho \circ v o \varsigma$

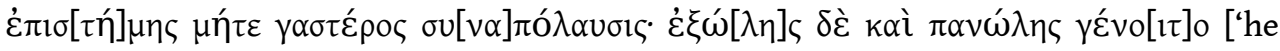
may neither get good fruits from the earth, nor succession of legitimate children, nor a marriage with a chaste woman, nor the affectionate fondness of friends, nor the benign gaze of the gods, nor navigable waters in the sea, nor any pleasure, neither from work nor from prudent skill/knowledge nor from his belly (food consumption); he may perish and be completely destroyed'].

85) G. MADDOLI, "Ara in onore di Alessandro ed Olimpiade", SCO 61.2 (2015), p. 137-143

[BE 2016, 447; SEG LXV 989]: Ed. pr. of an altar dedicated to Alexander the Great and

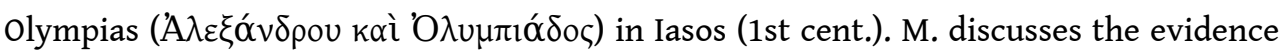
for the cult of Alexander until the 3rd cent. CE. Alexander had close connections to the Hekatomnids, and his cult and that of Olympias may already have been established during his reign. The interest in Alexander in the 1st cent. may reflect the perception of Augustus as a new Alexander.

86) C. MAREK and M. ADAK, Epigraphische Forschungen in Bithynien, Paphlagonien, Galatien und Pontos, Istanbul, 2016 [BE 2017, 539-540, 551]: Ed. pr. of 134 Greek and Latin 
inscriptions from Asia Minor; if not otherwise stated, all texts date to the Imperial

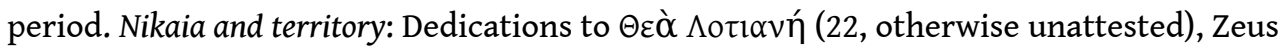

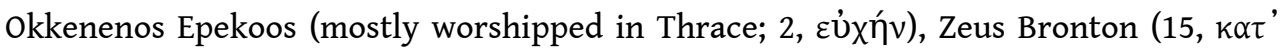
$\dot{\varepsilon} \pi \imath \tau \alpha \eta \dot{v} v$ ). An altar was set up for the cult of the Nymphs (3). An interesting epitaph for Markella (13) reports that her funerary altar was erected by her daughter and her son-

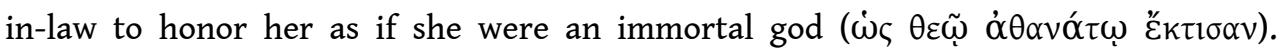
Iouliopolis: Two dedications to the otherwise unattested Zeus Auoreanos (37, by a

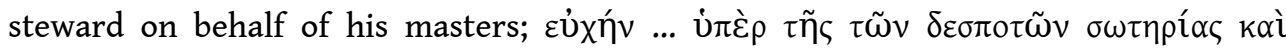

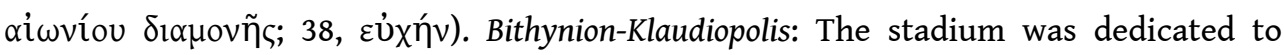
Hadrian (41). Dedications to Asklepios and Hygieia (56), and Hosion kai Dikaion (52, 57); one of the dedications to Hosion kai Dikaion (57) was made by Brion on behalf of the

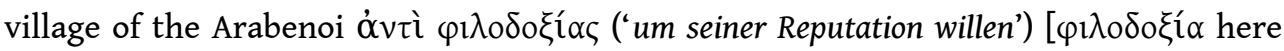
probably means generosity]. Krateia-Flaviopolis: Dedications: Apollonios dedicated an altar to Zeus Benios Epekoos 'in acknowledgment of the benefactions that he received from the bennos [cult association], in expression of piety and honor towards the

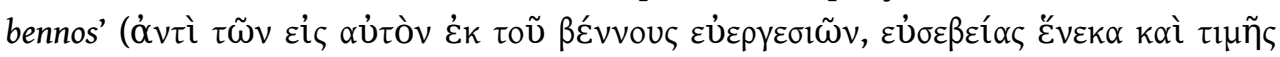

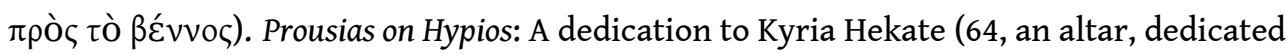
by a herald) and an honorific inscription for a high priest of the imperial cult who organized venationes and gladiatorial events (63). Gangra-Germanikopolis: An inscription records the construction or restoration of a temple of Thea Megale Hera (79). A couple made a dedication to Thea Artemis Progonike for the rescue of their son $(80, \dot{v} \pi \dot{\varepsilon} \rho$...

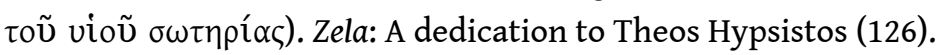

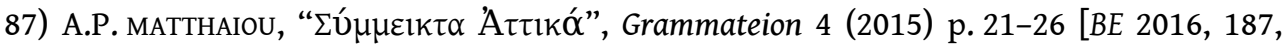
190; SEG LXV 45, 62]: 1. An inscribed boundary stone in Acharnai (SEG L 88, ca. 500-450)

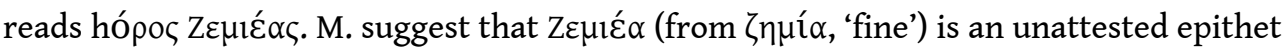
of Demeter; two votive reliefs, depicting an enthroned goddess and a woman and a

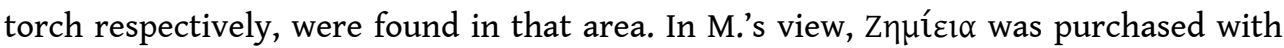
fines paid by those who had broken cult regulations of the goddess. 2. M. proposes a new restoration for a cult regulation of the deme of Paiania (IG I $\mathrm{I}^{3} 250$ lines 35-37,

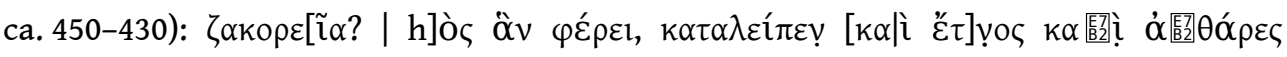

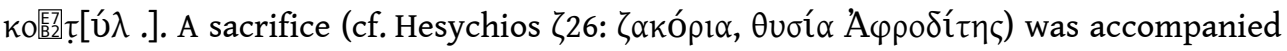

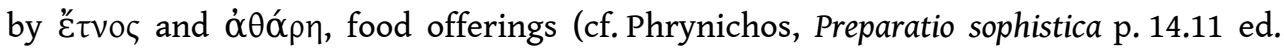
de Borres).

88) L. MEIER, "Kibyra und die Räuber: ein neues Grabepigramm", in Pisidia Yazıları Hacı Ali Ekinci Armağanı - Pisidian Essays in Honour of Hacı Ali Ekinci, Istanbul, 2015, p. 71-76 [BE 2016, 471; SEG LXV 1466]: Ed. pr. of a funerary epigram for Publius, who was killed by

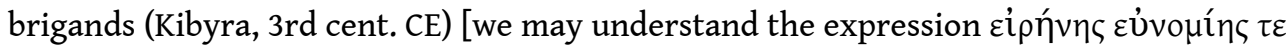

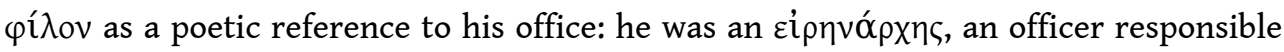
for policing the territory]. His wife, who set up the funerary monument, reports with

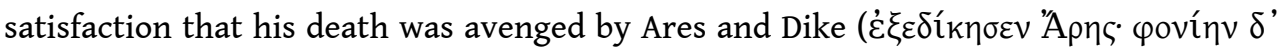

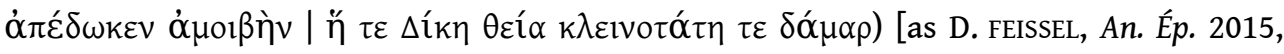

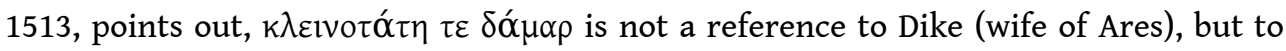
Publius' wife: 'la divine Justice ainsi que sa très illustre épouse lui ont rendu une sanglante réparation'].

89) J. MÉNDEZ DosunA, "Some Critical Notes on the New Dodona Lead Plates", ZPE 197 (2016), p.119-139: The A. suggests alternative readings and interpretations for 44 oracular tablets from Dodona (DVC 80, 186+187, 217, 267, 279, 300, 313, 336, 385, 387, 
$825,934,1108,1148,1193,1234,1334,1339+1340,1360,1375,1394,1395,1572,1846$, 2015, 2024, 2204, 2217, 2228, 2254, 2319, 2761, 2976, 2977, 2980, 3018, 3114, 3274, 3325, $3363,4157,4162)$. We present a selection of his interpretations. DVC 80: Changing the interpunction of this text, M. translates: 'Eumedes consults Zeus Naios, Diona and Tyche about the oak in the heroon: Shall I succeed in digging it up and replant (or: offer) it at the temple from there?' [for a different suggestion see EBGR 2013, 37]. DVC 1572: Assuming that part of the tablet is lost, M. argues that the question is not

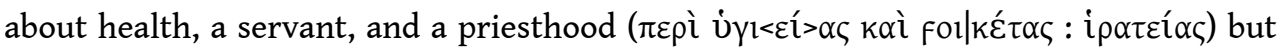

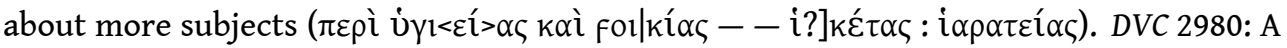
family wants to know whether a family member is dead, in order that his children and

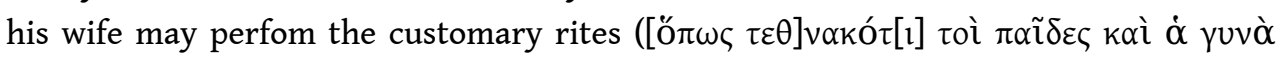

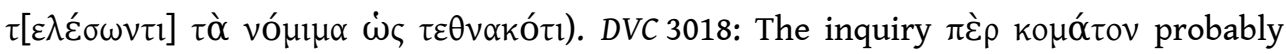
concerns a disease involving episodes of loss of consciousness.

90) N.P. MILNER, "Building Roman Lycia: New Inscriptions and Monuments from the Baths and Peristyle Buildings MI 1 and MI 2 at Oinoanda", AS 66 (2016), p. 91-124: Ed. pr. of inscriptions from Oinoanda. 1. A building inscription commemorates the restoration of a bath complex. The baths were dedicated (line 6: $\dot{\alpha} \varphi 1 \varepsilon \rho o \tilde{v} v[$ [oc]) to Emperor Vespasian and his sons Titus and Domitian (73 CE). 3. A victor in the contest of the Lykian Koinon (Koina Lykion) in the age-class of the boys dedicated a statue (3rd cent. CE).

91) M. NAFISSI, “Apollo Didymeus e Iasos, una relazione speciale: sulle aparchai inviate a Didyma e su un altare del dio ai Musei Archeologici di Istanbul", in S. PANZRAM, W. RIESS, and C. SCHÄFER (eds.), Menschen und Orte der Antike. Festschrift für Helmut Halfmann zum 65. Geburtstag, Rahden, 2015, p. 85-108 [SEG LXV 988]: N. republishes an altar of Apollo Didymeus in the Archaeological Museum in Istanbul and endorses its attribution to Iasos (ca. 175-150). Iasos, which regarded itself a colony of Miletos, had a close connection to the sanctuary of Apollo in Didyma. It made regular offerings of silver bowls to the sanctuary, possibly as the aparche offered by a colony to its mother city (I.Didyma 424, 428, 431-433, 449, 464, 475, 476).

92) M. NAFISSI, "Una dedica à Basileia da Iasos e il duplice culto della Madre degli Dei e della Madre Frigia", SCO 61.2 (2015), p. 119-136 [BE 2016, 450; SEG LXV 987]: Ed. pr. of a dedication to Basileia by a woman (Iasos, ca. 250-200). Basileia (cf. Basilis) is both the name of a goddess (IG XII.3.416) and an attribute of Hera, Aphrodite, Meter, and Meter Theon. In Iasos, this epithet probably refers to Meter Theon, who should be distinguished from Meter Phrygia [cf. EBGR 2012, 211, and 2015, 91].

93) N.M. NOviTchiKIN, Drevnsoti Bospora 20 (2016), p. 350-354: Ed. pr. of a dedication to

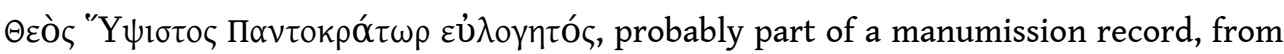
Gorgippia (late 2nd cent. CE); manumission records with the same dedicatory formula (CIRB 1123 and 1126) are associated with the Jewish community or reveal Jewish influence.

94) T. ÖZHAN, "New Inscriptions from Smintheion: Dedications, Epitaphs, and Fragments", in A. C. ÖZGÜNEL (ed.), Smintheion. In Search of Apollo Smintheus, Istanbul, 2015, p. 107-123 [BE 2017, 118, 456; SEG LXV 1120-1125]: Ed. pr. of six dedications found in the sanctuary of Apollo Smintheus in Alexandria Troas (Imperial period). 1. Dedication to Apollo Smintheus and to the Concord of the porters, possibly after the reconciliation of the members of a professional association $(\Sigma \mu \nu v \theta \varepsilon \tilde{\imath}$ A A 


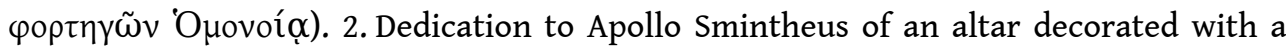
tripod and a lyre by a public slave. 3. Dedication to 'the god' (i.e. Apollo) and the friends (probably the members of an association). 4. A man dedicated an altar to Apollo Smintheus on behalf of his friends ( $\dot{v} \pi \dot{\varepsilon} \rho \tau \tilde{\omega} v \varphi \hat{i} \lambda \omega v$ ). 5. Dedication of a column. 6. Dedication of a building to Apollo.

95) H.S. özTüRK, "New Inscriptions from Cyzicus and Hadrianea at Halûk Perk Museum", Phaselis 1 (2015), p. 191-197 [BE 2016, 405; SEG LXV 1142]: Ed. pr. of a stele dedicated by M. Memmius Prophetes on behalf of the Emperors (Kyzikos, village of the Kindyrenoi, Imperial period). The stele shows a male bust flanked by a priest and a priestess, each holding a distaff (p. 191-193 no. 1).

96) H.S. öZTÜRK and F. DöNMÖZ-öztÜRK, "Nikaia'dan yeni yazitlar IV", Cedrus 3 (2015), p. 244-256 [SEG LXV 1163]: Ed. pr. of an altar (decorated with a tree, an eagle, a bucranium, and a thunderbolt) dedicated by two men for good agricultural produce in their villages ( p. 244f. no. 1).

97) H.S. ÖZTÜRK, "New Inscriptions from Göynük and Mudurnu IV", Cedrus 4 (2016), p. 287-297 [BE 2017, 549]: Ed. pr. of inscription from the area of Nikaia (Imperial period). 1. A posthumous honorific inscription was set up by the community of the Ospraimenoi or Spraimenoi for a local benefactor who had served as غ̇optápxns (responsible for festivals; an unattested word). The erection of the stele is dated with

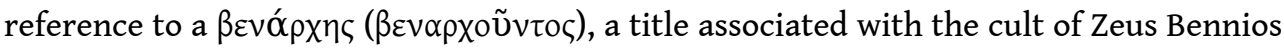

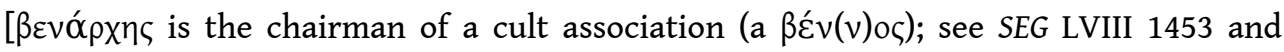

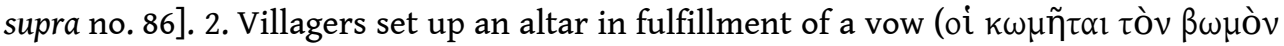
$\varepsilon \dot{U} \chi \tilde{n} \varsigma \chi \chi \alpha ́ \rho ı v ~ \alpha \dot{\varepsilon} \theta \eta \kappa \alpha v)$; the dedication is dated with reference to the 11th regnal year of Trajan and a priest.

98) M.J. osBoRNE and S.G. BYRNE, Inscriptiones Atticae Euclidis anno posteriores. Editio tertia. Pars I. Leges et decreta. Fasciculus IV. Leges et decreta annorum 300/299-230/29, Berlin, 2015: We note the publication of $I G I^{3} .1 .4$, which contains Athenian laws and decrees from $300 / 299$ to the liberation of Athens from the Macedonian garrison (229 BCE). For reasons of space, we only mention here texts involving temple inventories, cult regulations, and texts that were not already included in $\mathrm{IG} \mathrm{II}^{2}$. Cult regulations: A decree concerning the cleaning of the sanctuary of Aphrodite (879 = IG II ${ }^{2} 659=$ LSCG 39); a decree concerning the sacrifices offered by doctors to Asklepios and Hygieia $\left(914=I G \mathrm{II}^{2}\right.$ $771=$ LSCG 40). Temple inventories: Two decrees concern the compilation of inventories of dedications in the sanctuary of Asklepios and list the dedicated objects $(898,1010)$. Cult officials: Honorific decrees for a priest of Amphiaraos (902), the priestess of Aglauros (1002; cf. EBGR 1990, 227 and 1996, 19; cf.EBGR 2015, 54), the father of a

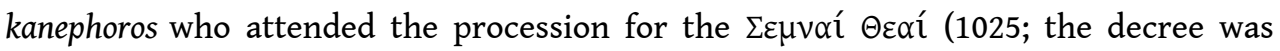
initiated by the priestess of Basile and the hieropoioi). Festivals: A decree honors the Athenian envoys to the festival Basileia in Lebadeia $(882,281 / 80)$. The honorific decree for Kallias of Sphettos mentions his contribution to the Panathenaia of 282/1 or 278/7 and the offering of the peplos to Athena (911 lines 64-70). Many decrees honor prytaneis and magistrates for the performance of religious duties and the offering of sacrifices (887-888, 896-897, 907, 910, 922, 926, 946, 951-952, 971, 973, 983, 1006, 1024, $1036,1054,1059,1066)$ as well as the men who supervised the rituals in honor of Zeus Soter and Athena Soteira (905). 


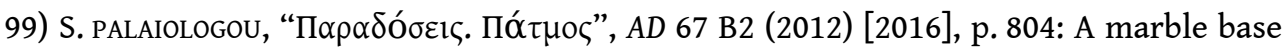
was delivered to the Department of Antiquities in Patmos; the block, built into the wall of a house, has on one side a crude representation of the portrait of a man [probably not ancient] and on the other an inscription, presented by P. in majuscules (1st

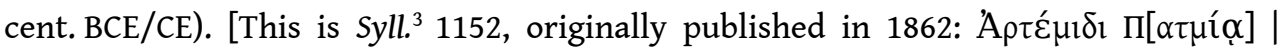

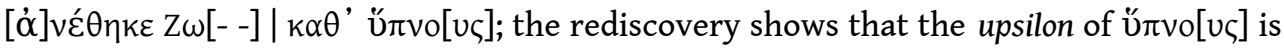
visible].

100) P. PEDERSEN and S. ISAGER, "The Theatre at Halikarnassos", in R. FREDERIKSEN, E.R. GEBHARD, and A. SOКоLICEK (eds.), The Architecture of the Ancient Greek Theatre, Aarhus, 2015, p. 293-317 [BE 2016, 455; SEG LXV 955, 957]: Ed. pr. of an inscription from the theater of Halikarnassos (p. 301) that records the dedication of the western pylon to Dionysos by Moschion, after he had served as an agonothetes (2nd cent.). The seat inscriptions of the theater (p.310-315) include seats reserved for a high priest

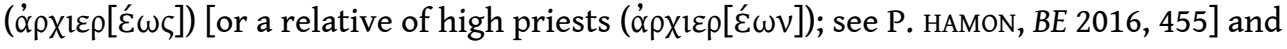

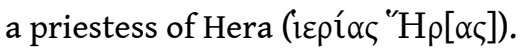

212 101) S. PEREA YÉBENES, "El voto de un soldado a Silvano - Zeus Dalbenus?", Geríon 33 (2015), p. 311-325 [BE 2017, 136]: Ed. pr. of a statuatte of Silvanus of unknown provenance, now in a private collection in Barcelona (early 2nd cent. $\mathrm{CE}$ ). According to

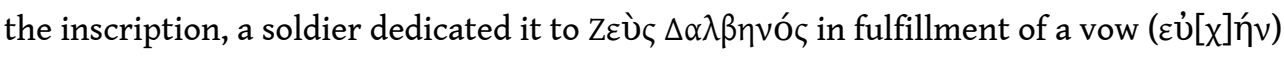

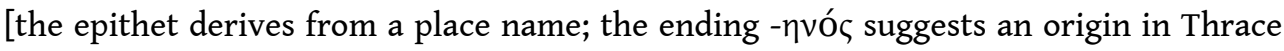
or Moesia].

213 102) D. PETRAIN and R. BENEFIEL, "Good Fortunes at Oplontis? (A Reconsideration of SEG 38.1001)", ZPE 200 (2016), p. 229-233 [BE 2017, 148]: A graffito in the villa at Oplontis had been read as TAEIC KANIEPEIC AГIE $\Lambda$ IC or TAEIC KAMEPEIC AГIENIC (SEG XXXVIII 1001). The

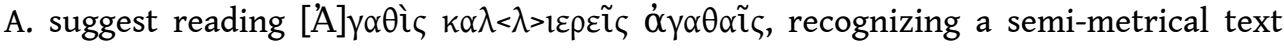
('Agathis, you sacrifice favorably with good [fortunes]') and a deliberate word play with the name Agathis [if the reading is correct, one may consider [A] ${ }_{\gamma} \alpha \theta i \varsigma \varsigma \kappa \alpha \lambda<\lambda>1 \varepsilon \rho \varepsilon \tilde{\varsigma} \varsigma$ A $\gamma \alpha \theta \alpha \tilde{i} \varsigma$, 'Agathis, you sacrifice to the Agathai, to the favorable goddesses'; $\alpha \gamma \alpha \theta \alpha$ í can be an attribute of the Nymphs or the Elpides (SEG XXXII $688=$ I.Histria 107, restored);

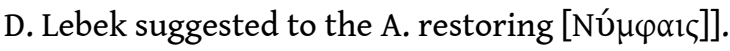

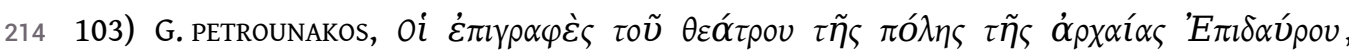
Athens, 2015 [BE 2016, 116; SEG LXV 222]: Ed. pr. of inscriptions written on the seats of the theater in the city of Epidauros. Some of the inscriptions commemorate the dedications of seats or prohedria seats by guards, agoranomoi, and damiorgoi to Dionysos (p. 285-292) and Apollo Lykeios (seat nos. 220, 245, and 283; 3rd cent.).

215 104) D. ReItzenstein, "Neue Inschriften aus Tlos: Kronoskult, Agonistik und Euergetismus", Chiron 44 (2014), p. 551-613 [BE 2015, 646; SEG LXIV 1415-1429]: Ed. pr. of inscriptions from Tlos (Imperial period). Several texts provide information on the agonistic culture of Tlos (the contest of Megala Kroneia) and Lykia. The most

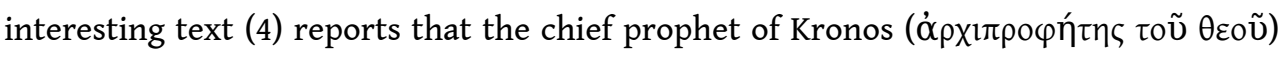
dedicated to Kronos $\mu \varepsilon ́ \gamma \propto \varsigma, ~ \theta \varepsilon o ́ \varsigma$ and Emperor Commodus the prize statue for the

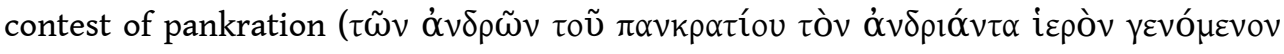
$\dot{\alpha} v \varepsilon ́ \theta \eta \kappa \varepsilon v$ ); the prize was dedicated to the god because the contest ended with no winner. Other honorific inscriptions for victors at the Megala Kroneia mention the agonothetai $(5,7,8,12-15)$, who sometimes also occupied the office of the Lykiarches

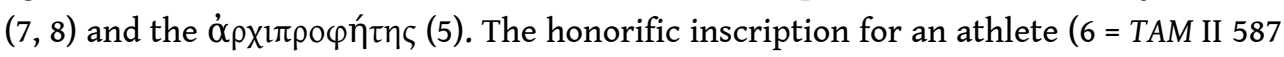


+ a new fragment) mentions that he had participated in all the Greek contests and in

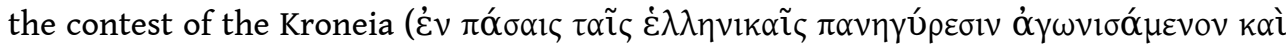

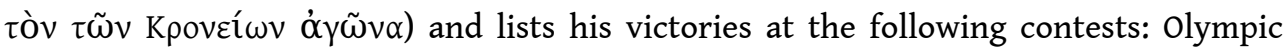
Games (4 times), Pythia (3 times), Nemea, Isthmia (restored), Eusebeia in Puteoli, Sebasta in Neapolis, Panhellenia, Olympia, Panathenaia, and Hadrianeia in Athens, Aspis in Argos (4 times), Haleia in Rhodes, Kommodeia in Miletos, Koina Asias in Smyrna, Augusteia and Traianeia in Pergamon, Olympia, Balbilleia, Artemisia Kommodeia in Ephesos, Olympia in Daphne near Antioch, Koinos Agon of Syria, Antiocheia, and Hadrianeia in Antioch, Herakleia in Tyros, Hadrianeia in Anazarbos, and the Periporphyros in Sidon, as well as contests with money prizes. The other texts

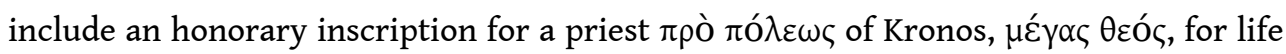

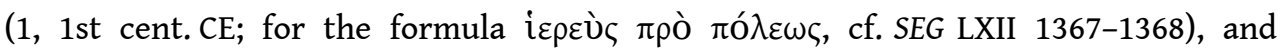
honorific inscriptions for a Lykiarches (2) and a high priestess of the provincial imperial cult in Lykia (3).

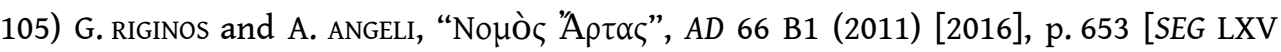
384]: The bronze spike of a lance was found in the area west of the theater of Ambrakia

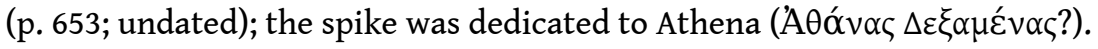

106) V.G. RIZZONE, "Letture e riletture di iscrizioni della Sicilia orientale", Seia 19/20 (2014-2015) [2016], p. 71-97 [SEG LXV 773]: Ed. pr. of a ring with a magical gem in the Museum of Syracuse (3rd cent. CE; 89f. no. 9); on the obverse, Helios is worshipped by a soldier; on the reverse, magical letters (repetitions of $\Theta \mathrm{A}$, $\mathrm{xOY}$, and sequences of vowels). R. republishes, with new readings, a dedication made in fulfillment of a vow by a

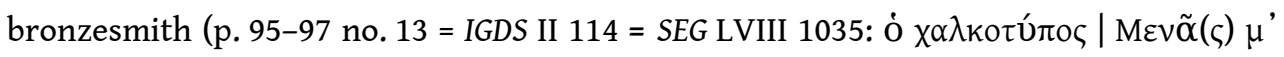

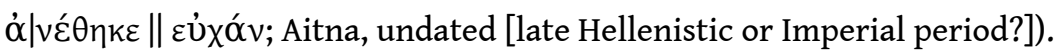

107) D. ROUSSET, J. CAMP, and S. MINON, “The Phokian City of Panopeus/Phanoteus, Three New Rupestral Inscriptions, and the Cippus of the Labyadai of Delphi", AJA 119 (2015), p. 441-463 [BE 2016, 277; SEG LXV 361-363]: The cult regulation of the Labyadai in

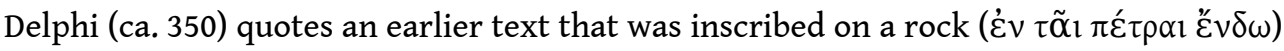
in Phanoteus/Panopeus in Phokis (CID I lines 29-31). This inscription, which can be dated to the late 6th cent., was found by J. Camp and students of the American School of Classical Studies in Athens in 1993. It is engraved on a rock that fell from the acropolis in antiquity, now lying near an opening in the fortifications, possibly in the area of an open-air sanctuary. The text refers to gifts (parts of sacrificial animals) made

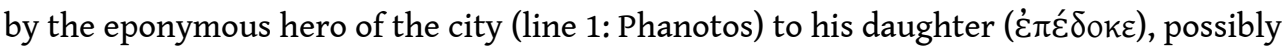
in the course of a mythical event that established regulations concerning a sacrifice: 'this is what Phanotos gave (as a dowry?) to his daughter Boupyga: the half-sheep

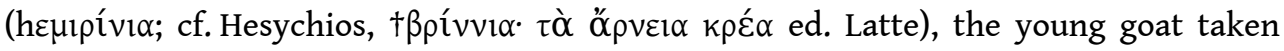

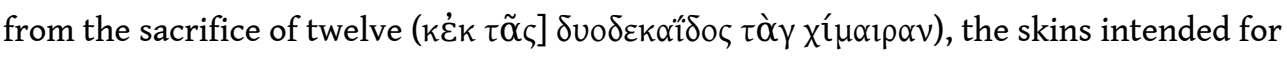

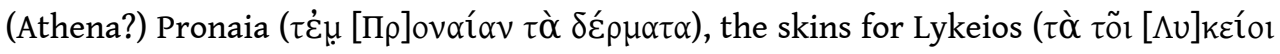

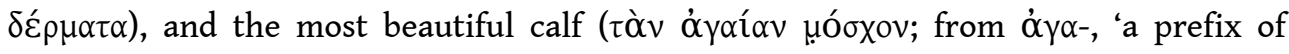
intensification indicating large size or superiority')'. Presumably, analogous gifts were to be provided at Delphi by consultants of the oracle from Phanoteus (cf. CID I 9 D lines 38-43). There also may have existed a mythological link between Athens and Phanoteus, as Theseus is said to have fallen in love with Phanotos' (other) daughter, Aigle (Plut., Theseus 20.1; 29.2). A second inscription (ca. 500-475), carved on the natural cliff face east of the regulation, is puzzling; the editors tentatively suggest that a group

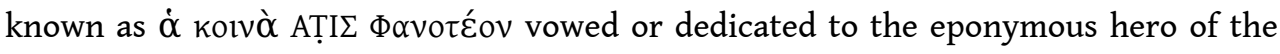




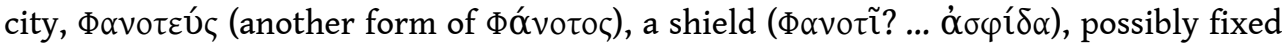

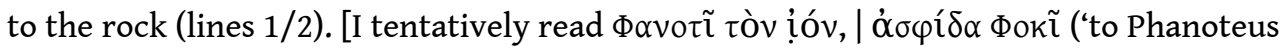
the arrow, a shield to Phokeus'); exactly as the hero's name is attested in two forms,

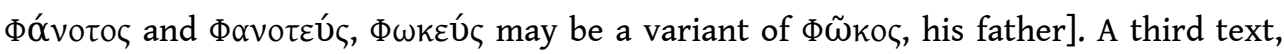
engraved on the rock in the same area, records a dedication to Dionysos (3rd cent.).

108) A.S. RUSSYAEVA, "Graffiti from the Southern Temenos in Pontic Olbia", ACSS 21 (2015), p. 251-279 [BE 2016, 346; SEG LXV 613]. Ed. pr. of 30 graffiti on vases found in the southern temenos in Olbia (5th cent.). They include dedications to Aphrodite - no. 13 with the unattested epithet $\Delta \eta \mu$ í [cf. the well-attested epithet חó $v \delta \eta \mu \circ]$ ] (1-14) -,

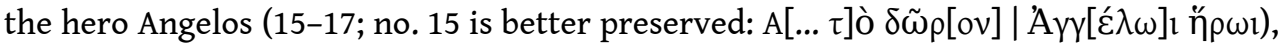
and unidentified divinities (18-21); there are several incerta, interpreted by R. as magical graffiti (22-27), and abbreviated names (28-30).

109) H. §̧AHIN and A. özDızBAY, "Dağlık Kilikia Kurşun Kalesi Tapınağı ve Stoasına İlişkin Yeni Öneriler", Adalya 17 (2014), p. 85-121: [SEG LXIV 1472-1473]: Ed. pr. of two dedications to Selene Epekoos (area of Diokaisareia, 1st/2nd cent.). The dedicants provided funds for the construction of one or more stoas.

110) H. şAHIN, “A New Dedicatory Inscription of Athena Oreia from Korykos", Philia 2 (2106), p. 143-148: Ed. pr. of an altar dedicated to Athena Oreia (territory of Korykos, Imperial perio). Her cult was limited in Kilikia (between Kalykadnos and Latmos and in the area of Mopsuhestia). The altar probably comes from the same sanctuary as dedications to Zeus Kodopas (cf. EBGR 2008, 141 = SEG LVIII 1654-1656).

111) S. Yu. SAPRYKIN and V.A. KUTAISOv, "The Cult of Asklepios in Kalos Limen”, Bosporskie issledovanija 31 (2015), p. 110-120 [BE 2016, 357; SEG LXV 595]: Ed. pr. of a dedication to Asklepios Epekoos from Kalos Limen in the territory of Chersonesos (3rd/2nd cent.).

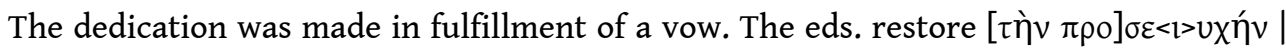

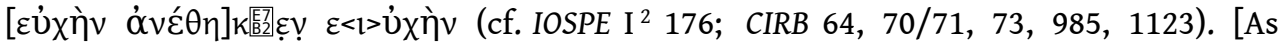

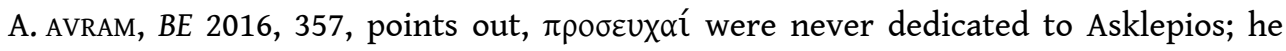

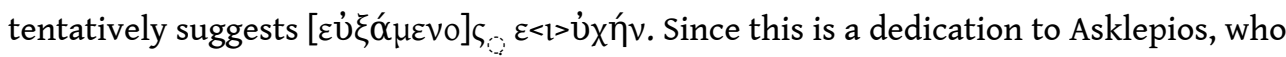

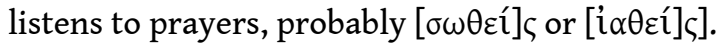

112) S. Yu. SAPRYKIN and S. Yu. vNUKOV, "Greek Inscriptions from Kara Tobe (northwest Crimea)", VDI 293 (2015.2), p. 98-102 [BE 2016, 354; SEG LXV 596]: Ed. pr. of a small fragment with the letters $\Pi \alpha \rho \theta \varepsilon[--]$, the beginning of a theophoric personal name or a dedication to Parthenos from a fortress Kara Tobe in the territory of Chersonesos in Tauris (ca. 200-150).

113) M. SAYAR, "Tarsus und Severus Alexander", EA 49 (2016), p. 177-186: S. presents an improved edition of an honorific inscription for Severus Alexander from Tarsos (see supra no. 78 and infra no. 137) and discusses the honorific titles and privileges of this city, including the title of a twice neokoros (cf. IGR III 879, 880; IdC 30).

114) I. SCHAAF, "Trick and Trade? The Eretrian Hymn to the Idaian Dactyls (IG XII,9 259)", in M.A. HARDER, R.F. REGTUIT, and G.C. WAKKER (eds.), Hellenistic Poetry in Context, Leuven, 2014, p. 301-322 [SEG LXIV 780]: New critical edition of the hymn to the Idaean Dactyls from Eretria IG XII.9.259; cf. IG XII Suppl. 558). In his commentary, S. discusses the association of the Daktyloi with magic and handicraft and their conflict with Meter Oreia (lines 35-48). He detects connections with Euboia: Memphis (line 15) is known from other sources as the wife of Epaphos, who according to Strabo (10.1.3 C445) was born in Euboia; Hephaistos (line 28) was also linked with Memphis (Herodotos 3.37), 
and Orion (line 26) had Euboian connections. Whether the birth alluded to in lines 16-

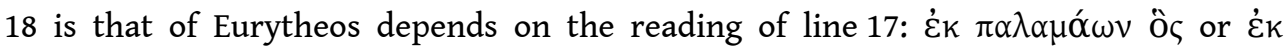
$\Pi \alpha \lambda \alpha \mu \alpha$ ó $\omega v o \zeta$.

115) G.P. schaus, "The Sanctuary: Site Description", in G.P. schaus (ed.), Stymphalos. The Acropolis Sanctuary, Vol. 1, Toronto, 2014, p. 12-35; "Miscellaneous Small Finds", ibid., p. 148-183; "Select Pottery from the Sanctuary and Nearby City Area", ibid., p. 216-225 [SEG LXIV 283-284]: The small finds from the sanctuary on the acropolis of Stymphalos include an Archaic bronze vase dedicated to Eileithyia (153f. no. 22). The name of the same goddess can be restored in a graffito on a Corinthian kalyx-krater (218 no. 6). These finds raise the question of whether the sanctuary on the acropolis was dedicated to Athena, as believed on the basis of a boundary marker of Polias (SEG XI 1111: [A $\theta \varepsilon v \tilde{\alpha} \varsigma$ ?] По $\left.\lambda_{\imath} \alpha \delta_{0}\right)$ ). S. wonders whether this stone was a boundary marker, a dedication, or an aniconic stele (p. 13f.).

116) G. SCHÖRNER, "Votivaltäre in Epidauros. Ein antikes Zeichensystem zur Kategorisirung von Kultmonumenten", in A. W. BUSCH and A. SCHÄFER (eds.), Römische Weihealtäre im Kontext, Friedberg, 2014, p. 55-66: S. offers a new interpretation of the encircled symbols and numerals on votive altars in Epidauros (IG IV ${ }^{2} .1$ p. 173-176 no. VIII; $308 \mathrm{CE}$ and later). The numbers may refer to the location of the altars or represent the symbols of specific deities. He argues that these signs and numerals were engraved in the 4 th cent. CE, in order to facilitate the performance of a ritual consisting of visiting the altars and making offerings ( $\pi$ pó $\theta v \sigma r \zeta ?)$.

117) N. SHARANKov, "Novi danni za trakiyskite stratezi", Archeologija (Sofia) 56 (2015.1/2), p. 62-78 [BE 2017, 351; SEG LXV 546, 549-550, 560, 564-565]: In a discussion of the history of the office of the strategos (governor of districts) in Thrace (1st cent. BCE-1st cent. CE), N. presents five inedita and republishes relevant inscriptions (the inedita are marked with an asterisk); we summarize the content of inscriptions with a religious interest. $1^{*}$. Honorific decree for the strategos of Mokaporis (Dionysopolis, ca. 11 BCE-

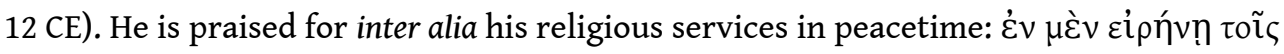

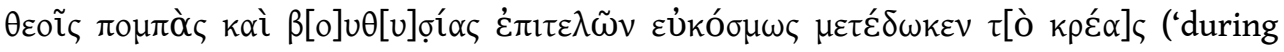
peacetime, he organized processions and sacrifices of oxen and distributed the meat in good order'). 2*. Honorific decree for a strategos (Dionysopolis, ca. $11 \mathrm{BCE}-12 \mathrm{CE}$ ). The man was given access to the council and the assembly immediately after the sacred

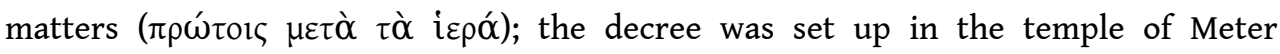

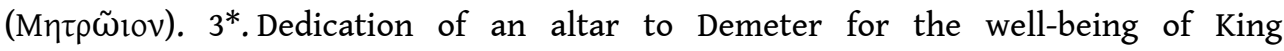
Rhoimetalkes II and Queen Pythodoris by the strategos Apollonios (Aquae Calidae, ca. 19-26 CE). $4^{*}$. Dedication to Demeter by the same Apollonios after a successful

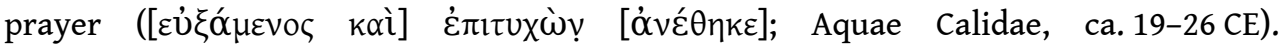
$5^{*}$. Dedication to Zeus Progonikos by Tib. Claudius Proklos, a priest (Apollonia Pontike, 1st/early 2nd cent.). 6. Dedication to the hero Bolbenos, whose name probably derives from a local place name (Augusta Traiana, 1st/2nd cent.). 8. Dedication to Kúproৎ

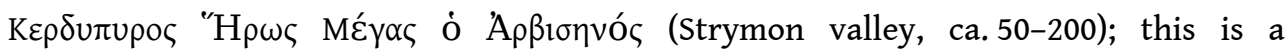

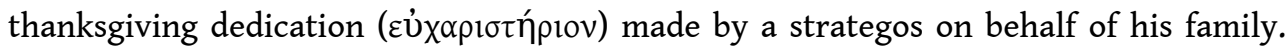
7. Dedication to Artemis (Nikopolis ad Nestum, early 2nd cent. CE; IGBulg IV $2338=\mathrm{V}$ 5928). S. suggests reading $\dot{0}<\rho>v \varepsilon 0<\sigma>\kappa o ́ \pi \eta \sigma \alpha v$ or $\dot{0}<\rho>v \varepsilon 0<\sigma>\kappa o \pi \eta ́ \mid \sigma \nu<\tau>\varepsilon \zeta$ in line 17 (OINEOPEKOПHEANA, IGBulg), recognizing a reference to divination. S. also observes that IGBulg III.1 1115 and 1116 join (Batkun, reign of Trajan). A strategos in Thrace and a

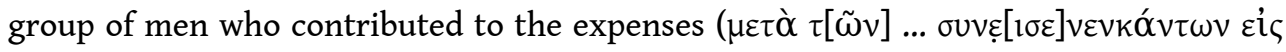




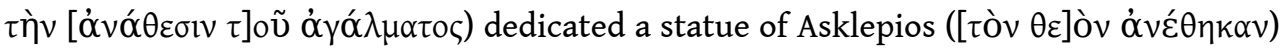
to Kyrios Asklepios Zylmisdrienos for their own well-being and health and that of their

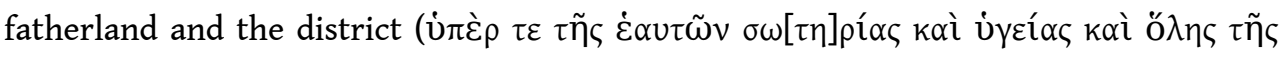
$[\pi \alpha] \tau \rho i ́ \delta o \zeta ~ \kappa \alpha i ̀ ~ \sigma \tau \rho \alpha \tau \eta \gamma i ́ \alpha \varsigma)$.

118) E. SIRONEN, Inscriptiones Graecae. Inscriptiones Argolidis, editio altera. Fasciculus III. Inscriptiones Corinthiae saeculorum IV. V. VI, Berlin, 2016 [BE 2017, 213]: The corpus of the Late Antique inscriptions of Corinth (IG IV ${ }^{2} .3$ ) assembles 594 inscriptions of the 4th-6th cent. (no new texts relevant to Greek religion). Dedications: A lead disc [label of a dedication; for such labels see EBGR 2013, 59 and 94] records the dedication of Syrianos

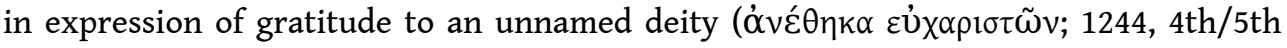
cent.). Pagan imagery: A Christian grave epigram for Petros, who died 21 years old (1478, 5th/6th cent.), uses pagan vocabulary and imagery: Petros was snatched away by

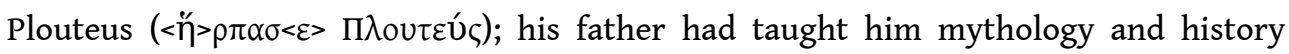

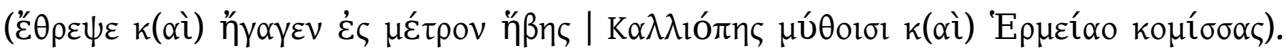
Similar vocabulary is often used in epigrams whose religious context (Christian or polytheistic) cannot be determined. An anonymous poet is designated as Movoó $\omega v$

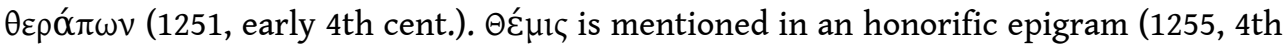

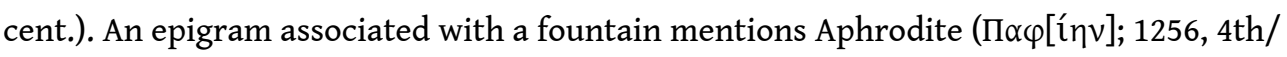
5th cent.). Corinth is called the land of Sisyphos (1481, 6th cent.). Prayers against

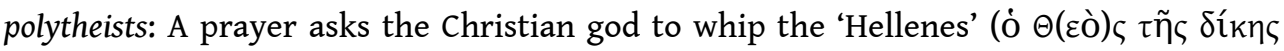

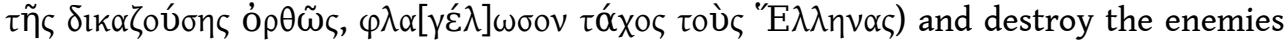
of a barber's sons (1279, 4th/5th cent.). A similar prayer, asking God to kill an

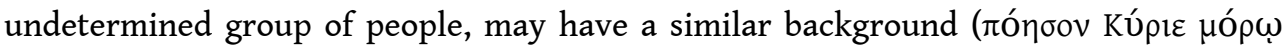

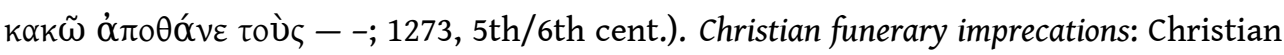
funerary imprecations use specific Christian formulas (1419: the curse of Anna and

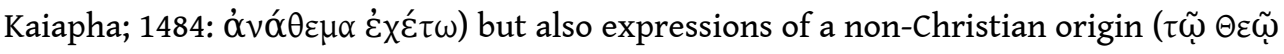

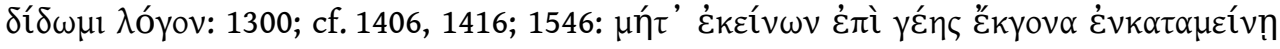

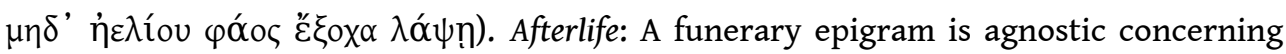

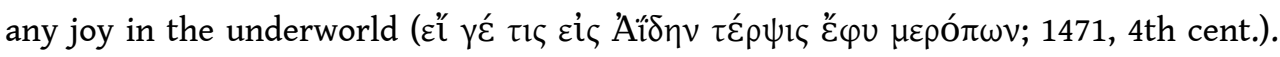
Defixiones: A Latin 'prayer for justice' invokes Demeter, Kore, Diana, Mars, Mercurius, Venus, and a god whose name is not preserved, 'the gods who inhabit this temple', to take revenge for him (ute de[vinc]iatis me; 1794, 4th cent.).

119) A. SOWDER KOCH, "Far from the Fountain: Inscriptions on Bronze Hydriai and the Use of Water Jars in Ancient Greece", BABesch 90 (2015), p. 13-42 [BE 2016, 137; 2017, 290]: The A. studies the function of 53 inscribed bronze hydriai (6th-4th cent.). These were mostly given as prizes in athletic contests ( 23 objects), but also as dedications to gods (7 objects), gifts, and grave goods. Hydriai were given as prizes in contests in Attica (1.1: in honor of Artemis; 1.11-12: Poseidonia at Sounion; 1.18-1.20: Anakeia; 1.23: contest for the war dead), Argos (1.4-7: Heraia), Kleitor (?; 1.17), Boiotia (1.13-14: Thebes; 1.15: Tanagra; 1.16: Thespiai, contest in honor of Herakles), Phokis (1.8: in honor of the Dioskouroi), Thessaly (1.21: contest in honor of Protesilaos), Rhodes (1.10: Halieia), Mylasa (1.9: contest in honor of Zenoposeidon), in funerary contests (swn place: 1.17; Lampsakos: 1.22), and in an undetermined contest (1.2). A hydria is possibly designated as an award for excellence in battle (1.3: $\mu \alpha \chi \varepsilon\{$ í $\alpha$ ). Bronze jars were dedicated to Zeus in Athens (2.7), Zeus Hellanios in Aigina (2.6), Artemis and Demeter in Elis or Arkadia (2.3), Demeter (2.2, unknown provenance), the Muses (in Boiotia?; 2.4), Zeus in Nemea (2.1), and Herakles (2.5, unknown provenance). 
120) K. STAUNER, "Die bilinguale Weihung des C. Annius Maximus, enturio der legio XVI Flavia firma", Philia 2 (2016), p. 113-122: Ed. pr. of an altar from southern Lykaonia

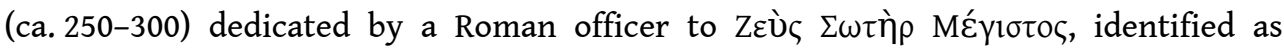

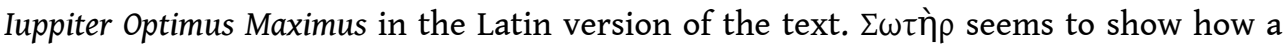
soldier understood 'Optimus'.

121) J.-Y. STRASSER, "Inscriptions agonistiques de Rhodes", Philia 1 (2015), p. 57-76 [BE 2016, 371; SEG LXV 652-653]: S. recognizes in the honorific inscription for the athlete Pythion (Rhodes, SEG LVIII 518) references to an extra-ordinary achievement: he won mutliple consecutive victories in three disciplines (boxing, wrestling, and pankration)

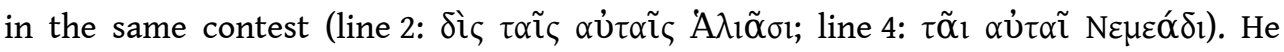
reconstructs his career that can be dated to ca.185-175. He also offers a new critical edition of the agonistic inscription recording the victories of a Rhodian runner (Fl. Apollinarions?), who was victorius at the Kapetolia in Rome, the Aktia in Nikopolis, and the Sebasta in Neapolis.

122) J.-Y. STRASSER, “Un citharède de Cos (IG XII 4, 2, 1166)", REG 128 (2015), p. 659-672 [BE 2016, 379]: S. presents a new critical edition of the agonistic inscription for a citharode from Kos (IG XII.4.1166), whose victories in numerous trieteric and

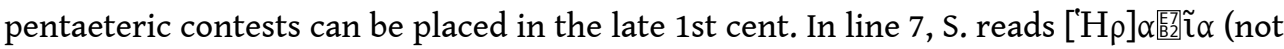

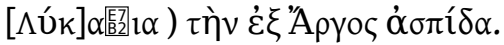

123) J.-Y. STRASSER, “Deux champions d'Anatolie”, EA 49 (2016), p. 137-155 [BE 2017, 480, 563]: S. discusses the career of Iulius Bassus, herald and tragedian, five-time periodonikes and victor more than 260 times (I.Didyma 183; IAG 74; Ca. 90-120 CE), and that of his homonymous son, tragedian, comedian, and citharode (I.Didyma 183; IGUR 261-263, mid-2nd cent.CE; p.137-150). As regards the puzzling expression kovvi

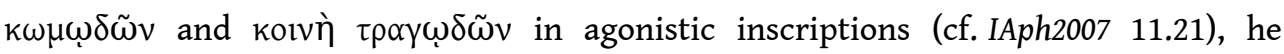
tentatively suggests that these were contests in which both tragedians and comedians were given the same subject (p.148). S. also discusses the career of the runner M. Aurelius Abas of Adada (IAG 76), whose victory at the Epinikia of Ephesos, an extraordinary celebration, he dates to ca. $180 \mathrm{CE}$. This man is to be identified with a praefectus cohortis known from an inscription at Tymbriada (SEG XXXV 1408, early 3rd cent. $\mathrm{CE}$ ), where he served as high priest and agonothetes of a local contest. He set up the statue of the winner in pankration in the age-class of the ageneioi.

124) J.-Y.STRASSER, "Une expression agonistique chez Saint Paul et dans trois inscriptions anatoliennes", REG 129 (2016), p. 369-403 [BE 2017, 29]: The expression vo $\mu i ́ \mu \omega \varsigma \dot{\alpha} \theta \lambda \varepsilon \tilde{\tau} v$ in Paul (2 Tim 2,3-6) is paralleled by similar expressions in honorific inscriptions for athletes. It refers to the conduct of an athlete in accordance with the principles of the athletic 'profession' (training, lifestyle, conduct during and after the contests).

125) S.V. TRACY, “Agora I 6701. A Panathenaic Victor List of ca. 190 B.C.", Hesperia 84 (2015), p. 713-721: [BE 2016, 177; SEG LXV 123]: T. presents a new critical edition of a victors' list of the Panathenaia (Athens, ca. 190; Agora XVIII 114 no. C197), and discusses the date, the events mentioned in it (boxing, pankration, stadion, diaulos), and the winners (men from Asia Minor). The list was the central block of a monument consisting of three contiguous orthostate blocks.

237 126) N. TRIPPÉ, “Une lettre d'époque classique à Thasos”, $B C H$ 139/140 (2015/2016), p. 43-65 [BE 2017, 422]: Ed. pr. of a clay tablet inscribed before firing (cf. a similar tablet 
from Emporion: G. DUNST, "Ein griechisches Tontäfelchen von der Küste bei Ampurias”, $\operatorname{MDAI}(M) 10$ [1969], p. 146-154). The tablet was found in a domestic context in Thasos (early 5th cent.) and contains the beginning of a letter sent by Euarchos to Echion with an unknown request ( $\kappa \varepsilon \lambda \varepsilon \cup ́ \varepsilon 1)$. Zeus Patroios, already attested in Thasos, is mentioned

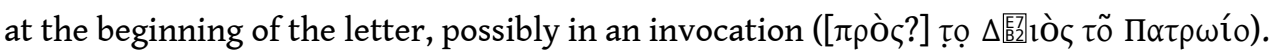

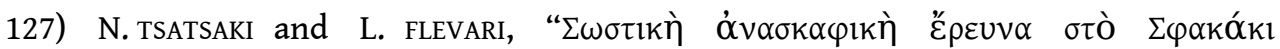

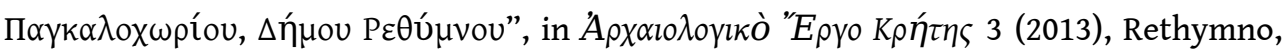
2015, p. 343-352: Excavations at the cemetery in Sfakaki, near Rethymnon, have added yet another Dionysiac/Orphic leaf (gold lip-band) to the numerous Cretan texts of this

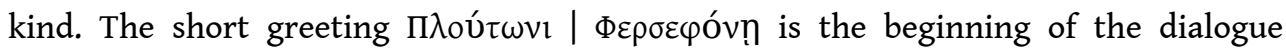
between the deceased person and the chthonic powers [cf. EBGR 1998, $89=$ SEG XLVIII and EBGR 2010, 196 no. 9 = SEG LX 999, also from Sfakaki).

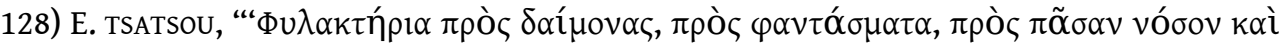

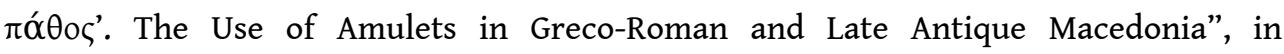
A. NIKOLOSKA and S. MÜSKENS (eds.), Romanising Oriental Gods? Religious Transformations in the Balkan Provinces in the Roman Period: New Finds and Novel Perspectives, Skopje, 2015, p. 113-131 [SEG LXV 535 bis]: T. discusses the use of amulets in Macedonia, focusing on the iconography and inscriptions on three inscribed amulets and three uninscribed pieces: 1) Amulet of red jasper; Herakles fighting with the lion of Nemea on the obverse, the letters KKK on the reverse (Thessalonike, 3rd cent. CE ); amulets of this type were used against colic. The three kappas, also used in the magical formula KO OKEP | КО ОПО | СІРКК found on other amulets, may be an abbreviation 'Kadosh' ('sacred') written three times (116/117). 2/3) Two heliotropia, one inscribed (see infra no.63) (small caps?), the other uninscribed, with a representation of Bes Pantheos (Thessalonike, 3rd cent. CE). 4) Amulet of agate attached to a ring; on the obverse a snake with lion's head and a crown with rays, on the reverse the inscription Xvoũ The amulet was probably used against stomachache (Pella, 2nd cent. CE). 5/6) Two uninscribed amulets, one with a variant of the iconography of Abrasax (a snake-legged god with a man's head) and one with a squatting woman, probably holding a uterus symbol (Dion, 3rd cent. CE).

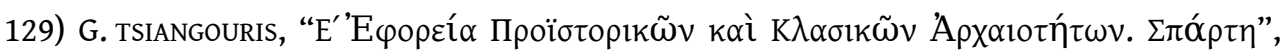
AD 65 B1 (2010) B.1 [2016], p. 456-463 [SEG LXIV 242]: T. reports the discovery in Sparta of a stamped tile belonging to a sanctuary of Athena ( $\delta \alpha \mu o ́ \sigma 1 о \varsigma$ 'A $A \alpha v \tilde{\alpha} \varsigma ;$ p. 463).

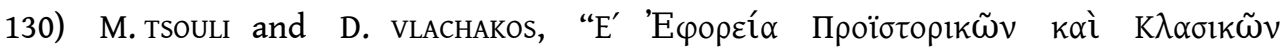

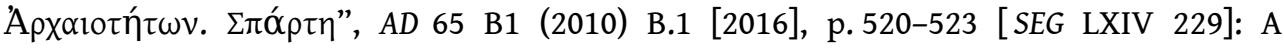

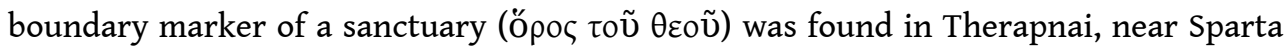
(undated; p. 520).

242 131) A. tziafalias, R. Bouchon, and B. Helly, "Lois de Larisa : règlement relatif à des célébrations religieuses à Zeus et à Ennodia", Studi Ellenistici 30 (2016), p. 69-101 [BE 2016, 290]: Ed. pr. of an inscription from Larisa that contains the first 10 lines of a cult regulation concerning a festival for Zeus and Ennodia, who shared a cult in a sanctuary outside of Larisa, at Solouneia (ca. 17-150). The text, part of a dossier of at least 14 laws inscribed in a public place, provides instructions concerning a procession and a sacrifice, the obligations of the priest, the herald, the sacrificial priest, and the cook, and the sacrificial animals (a white sheep for Ennodia, a ram for Zeus, a black sheep mentioned in an unclear context). 
132) A. TZIAfALIAS and L. DARMEZIN, "Dédicaces d'affranchis à Larissa (Thessalie)", $B C H$ 139/140 (2015/2016), p. 137-210 [BE 2017, 293]: Ed. pr. of 52 dedications inscribed on blocks that were reused for the construction of the second theater of Larisa in the 1st cent. Originally, they belonged to a circular building located in the sanctuary of an unknown deity (late $3 \mathrm{rd} / 2 \mathrm{nd}$ cent.). The dedicants are freed slaves who made the

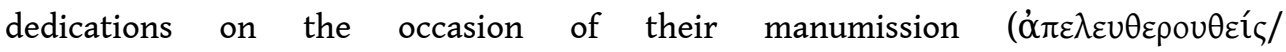

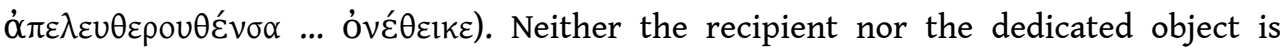
mentioned.

133) A. TZIAFALIAS, D. KaRAgounis, R. BOUCHON, L. DARMEZin, and B. helly, "Larissa, Balbus Minor et la Domus Augusta. Le thêatre de la cité au miroir de la politique diplomatique", AEThSt 4 (2012) [2015] I, p. 299-306 [BE 2015, 396; SEG LXV 377-378]: The A. report on the discovery of honorific inscriptions for the senator L. Cornelius Balbus and members of the family of Augustus in the theater of Larisa (late 1st cent. BCE/early 1st cent. CE). The inscriptions honor Augustus ( $\Theta \varepsilon o ́ v, ~ \Theta \varepsilon o \tilde{~} \pi \alpha \tilde{i} \delta \alpha)$, Tiberius, Germanicus, and Livia,

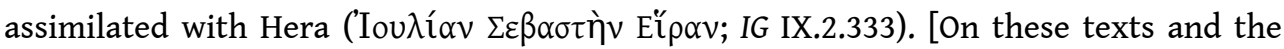
imperial cult in Thessaly, see also R. BOuchon, "Les Thessaliens et le culte des empereurs de Rome: tradition, intégration, polycentrisme et jeu d'échelles", in A. KOLB and M. vitAle (eds.), Kaiserkult in den Provinzen des römischen Reiches - Organisation, Kommunikation und Repräsentation, Berlin/Boston, 2016, p. 289].

134) A. tZiAfalias, R. Bouchon, L. DARMeZin, J.-C. DeCourt, B. helly, and G. LuCAS, Corpus des inscriptions d'Atrax en Pélasgiotide (Thessalie), Athens/Paris, 2016 [BE 2017, 283]: The corpus of the inscriptions of Atrax presents 513 texts, including many inedita (marked with an asterisk). Dedications to: Aphrodite ( $49, *^{*}$ ), Apollo (51; by daphnophoroi and their chief), Apollo Agreus (52, *53), Apollo Hetdomaios (sc. Hebdomaios; 54), Apollo Lykeios $\left({ }^{*} 55\right)$, Artemis (by women, to mark the passage from one age group to another: 56-64; see infra; by men: 65; by a woman: 66), Artemis Soteira (67; عن̉ $\xi \alpha \mu \varepsilon ́ v \eta)$, Artemis

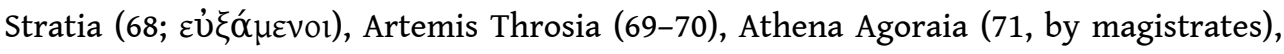

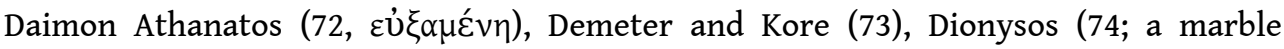

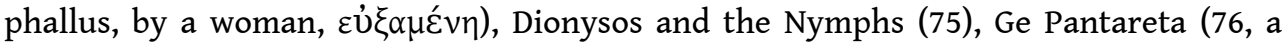
unique epithet), Helios, $\pi \rho \tilde{\omega} \tau o \varsigma$ $\beta \alpha \sigma \imath \lambda \varepsilon \dot{v} \varsigma$, the Theoi Patroioi and all the goddesses (77),

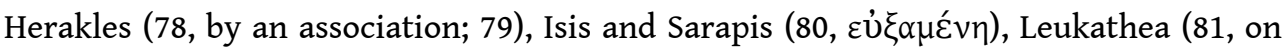
behalf of a family member), Meter Theon (82), the Nymphs Naiades (83), Poseidon (85: a

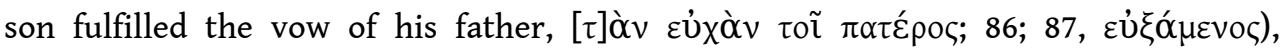
Poseidon Patrageneus (88), Themis Agoraia (89, by magistrates), Zeus Homoloios (9091), Zeus Kataibatas (92), Zeus Morragetas (Moiragetias?) (*93), Zeus Thaulios and (Zeus?) Tharaios (?, *94), Zeus Thaulios (95; *96, by a family group), Zeus Tritodios (9798), all the gods (99: Theoi Hapantes; 100: the gods, by an association of shepherds; 101: Theoi Pantes and Pasai), and Heros Poliphylax (84). The addressee is not mentioned or cannot be determined in a series of dedications (102-149). Some of these dedications were made by magistrates (102-103) and groups of men (104-105), family groups (106), and associations $(108-109,117)$. Five dedications were made by priests and priestesses

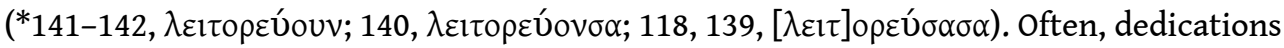

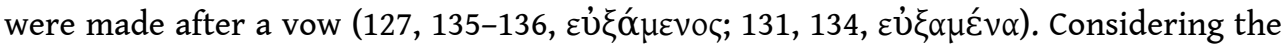
evidence provided by dedications, mainly to Artemis $(56-64,108,118,139,140)$, the eds.

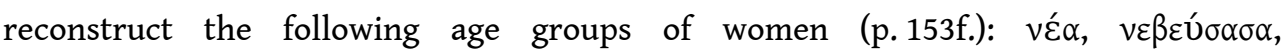
$\dot{\varepsilon} \pi 1 v \varepsilon \beta \varepsilon \dot{v} \sigma \alpha \sigma \alpha, \tau \alpha \gamma \varepsilon \dot{\sigma} \sigma \alpha \sigma \alpha$. Associations: A cult association of worshippers of Herakles

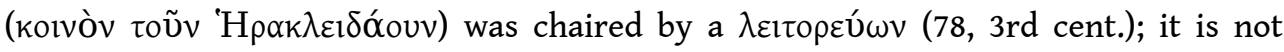


known to which god two associations were devoted, one chaired by a man (109,

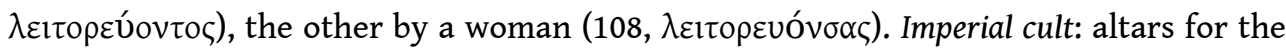

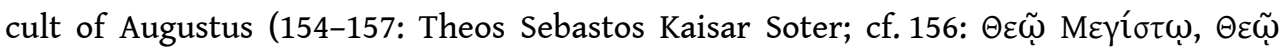

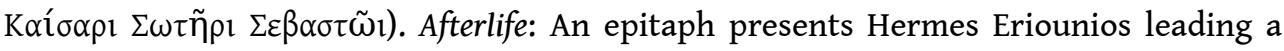

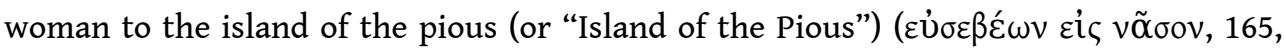
3rd cent.). Religious mentality: A dead man speaks from his grave and regrets the fact

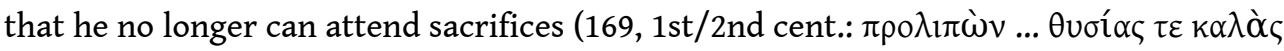

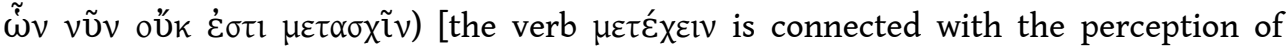
sacrifice as a shared religious experience; this experience could be remembered as such, as I argued in "Rituals between Norms and Emotions: Rituals as Shared Experience and Memory", in E. StaVRianopoulou (ed.), Rituals and Communication in the Graeco-Roman World (Kernos Suppl. 16), Liège, 2006, p. 211-238; Herodes Atticus records in an inscription his memories of sacrifices offered to Nemesis together with

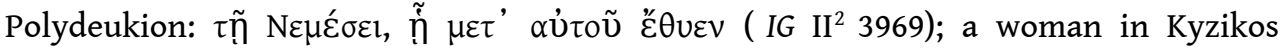
commemorates in the epigram for her son the joy he had experienced in offering

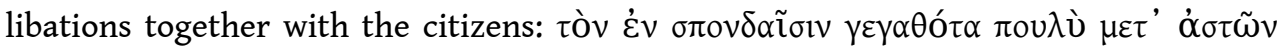
(SGO II 08/01/53)]. An epitaph is dedicated to Hermes Chthonios (500). Varia: A fragmentary text $\left({ }^{*} 1\right.$, late 3 rd cent.) contains the verdict in a lawsuit sucessfully pursued by the family group of the Kelaindai against a certain Prom $(\mathrm{a} / \mathrm{e})$ theus. According to the eds., Damarchos pronounced the verdict, according to which Prom(a/ e)theus should be excluded from the joint cults of the family groups of the Kelaindai,

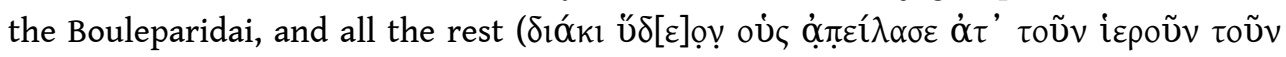

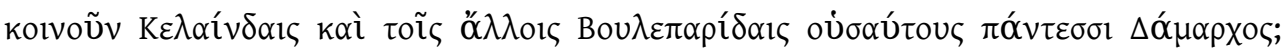
'c'est pourquoi, ils ont approuvé la décision de Damarchos de l'exclure des cultes communs aux Kélaindai et aux autres Bouléparidai ainsi qu'à tous'). The text attests the existence of cults which were restricted to certain family groups. Sanctuaries: the following cult places are mentioned: the sanctuary of Apollo Lykeios (11, the place where official documents were inscribed) and the sanctuary of Protesilaos (5). A boundary marker of a sanctuary is inscribed with a prohibition, probably against moving the boundary stone: i $\varepsilon \rho o ́ v \cdot \mu \varepsilon i$ $<\varphi>\varepsilon$ pel (503, ca. $300 \mathrm{BCE})$. Calendar: The numerous manumission records (21-48) provide information on the month names of Atrax: Itonios, Themistios, Hermaios, Leschanorios, Aphrios, Thyos, Homoloios (p. 108f.).

135) R. van bRemen, "Olympichos and Mylasa: A New Inscription from the Temple of Zeus Osogo", EA 49 (2016), p. 1-26 [BE 2017, 500]: Ed. pr. of a decree, probably from the temple of Zeus Osogo in Mylasa, concerning estates, gardens, and buildings purchased by Olympichos, Seleucid general and later dynast of Karia, from Queen Laodike (Laodike I, the wife of Antiochos II?) and donated to Zeus Osogo (ca. 250-240). This donation was promised by Olympichos with an already known letter (I.Labraunda 8); the decree implements Olympichos wishes about the leasing of these properties to generate income for the celebration of the monthly festival of Zeus. These lands adjoined the sacred land of Zeus Labraundos.

247 136) L. vecchio, "Su una laminetta oracolare da Dodona (Lhôte 113)", PP 70 (2015), p. 227-242 [SEG LXV 394]: An oracular enquiry from Dodona (SEG XIX 428; LVI 659; Lhôte, Lamelles oraculaires no. 113; ca.350-300) concerns, in V.'s interpretation, a dispute between Satyros, the owner of a valuable vase ( $\sigma \kappa u ́ \varphi \circ)$ ) and Dorilaos, the owner

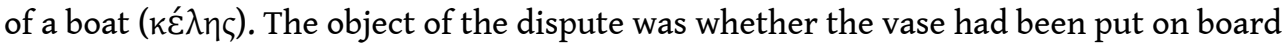

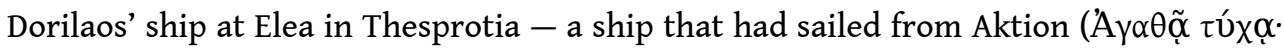




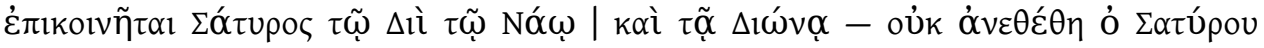

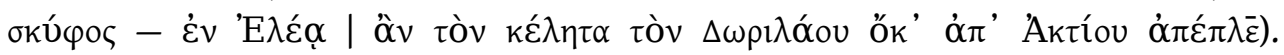
Enquiries concerning navigation are common among the Dodona tablets (DVC 228B, 283B, 366A, 1244, 1453B, 1483A, 1772A, 1809, 2054A, 2261A, 2363B, 2546A, 2610A, 3030A, 3656B, 3742B, 3946B, 4154B; V.). [This is yet another example of an oracular tablet concerning a legal dispute; two responses, a positive and a negative one, were written

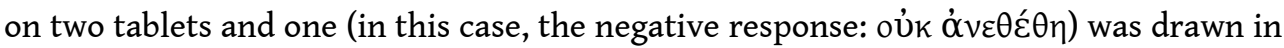
a process of cleromancy; see EBGR 2013, 37 and A. CHANIOTIS, "The Oracular Gods of Dodona Confronted with Legal Disputes", in M. KALAITZI et alii (eds.), Boreio-Helladika. Tales from the Lands of the Ethne. Essays in Honour of Miltiades B. Hatzopoulos, Athens, 2018, p. 321-341].

137) M. vitALE and N. HÄCHLER, "Anmerkungen zu einem Statthalter der Provinz CiliciaIsauria-Lycaonia", ZPE 199 (2016), p. 264-270 [SEG LXV 1541]: V.-H. present an improved edition of an honorific inscription for Severus Alexander from Tarsos (235/6 CE; see supra no. 113). The emperor's statue was dedicated to Athena (line 26). They suggest restoring A $\theta \eta\left[v \tilde{\alpha}\right.$ $\left.\Pi \alpha \lambda \lambda \alpha_{\alpha} \delta_{1}\right]$. This epithet is attested on Tarsian coins.

138) O. voroshilova and N. Zavoykina, "The Tombstone of Mokkos, Thiasotes from Phanagoreia", in Phanagoria 4.2. Materilay po arhologii i istorii, Moscow, 2016, p. 24-39 [in Russian; BE 2017, 397]: Ed. pr. of an honorific inscription from Phanagoreia (1st/2nd

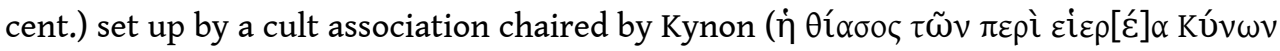

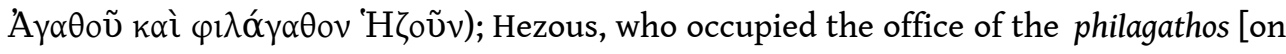
this office in cult associations in Phanagoreia, Pantikapaion, Hermonassa, and Tanais, cf. e.g. CIRB 36, 76, 79-84, 86, 88-93, 96, 97, 99, 100, 102, 103, 105, 107, 1016, 1054, 1259, $1260,1262-1264,1268,1277-1282,1284,1287,1288,1291]$, has a name probably of Skythian origin.

139) R.S. WAGMAN, The Cave of the Nymphs at Pharsalus: Studies on a Thessalian Country Shrine, Leiden, 2016 [BE 2016, 288]: W. discusses the topography of the 'Cave of Pantalkes' near Pharsalos, the finds, and the cult. He republishes with exhaustive commentary the two inscriptions carved on the rock (SEG I 247-248) at the cave's entrance (p. 57-93), adducing numerous parallels for the particular devotion shown by Pantalkes. He argues that a cult of the Nymphs must have existed at this site before Pantalkes built a stairway to the cave and planted a sacred grove in the 5th cent. The last lines of his dedication may refer to the dedication of a laurel, but the reading is uncertain. The second text (4th cent.) is a metrical commemoration of Pantalkes' work (by a local poet?) that praises the founder of the cult, names the gods of the cave - the Nymphs, Pan, Hermes, Apollo, Herakles, Chiron, Asklepios, and Hygieia - and mentions the gifts that Pantalkes received from the Nymphs (a noble heart), Herakles (strength), Apollo and Hermes (health and prosperity), and Chiron (knowledge and musical skill). The worshippers were not limited to passing peasants but must have included people from the city.

251 140) C. WALLNER, "Xenoi Tekmoreioi: ein neues Fragment", EA 49 (2016), p. 157-175 [BE 2017, 533]: Ca. 45 inscriptions from the border region of Phrygia and Pisidia concern a

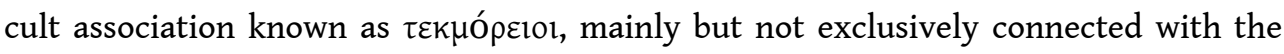
cult of Mes Askainos. The nature of the ritual or activity designated as $\tau \varepsilon \kappa \mu о \rho \varepsilon v ́ \omega$ is not known. W. presents the ed. pr. of an opisthographic plaque, probably from the territory of Antioch in Pisidia (ca. $260 \mathrm{CE}$ ), that provides the names of members of this association and the number of $\chi \alpha \lambda$ kí $\alpha$ (most likely bronze coins) paid by them. 
141) P. WEIss, "Eine tabella defixionis, die spanischen Vibii Paciaeci und Crassus", Chiron 46 (2016), p. 223-263: Ed. pr. of a lead tablet from Ostia (second half of the 1st cent.). The tablet was not folded but nailed to a wall, with the inscribed face made invisible (p. 240). The Latin text provides a list of 32 or 33 men and women, mostly manumitted slaves and their offspring. The interest of this text lies in the fact that most of the cursed individuals were freedmen of the Vibii Paciaeci, a well-known family of Roman knights from Spain, closely associated with Crassus and, apparently, with trade interests in Ostia.

142) A. williams, "Xenocratia and the Hieron of Cephisus", in J. Bodel and N. Dimitrova (eds.), Ancient Documents and their Contexts, Leiden, 2014, p. 67-81 [SEG LXV 58]: W. discusses in detail IG $\mathrm{I}^{3} 987=I G \mathrm{II}^{2} 4548$, which records the dedication of the shrine of Kephisos by Xenokrateia (Athens, ca. 410-400). Such a pivate foundation by a woman can be explained in view of the wealth of her oikos.

143) P. wILSON, "The Festival of Dionysos in Ikarion. A New Study of IG $I^{3} 254$ ", Hesperia 84 (2015), p. 97-147 [BE 2016, 166; SEG LXV 46-47, 49]: W. presents a new critical edition of the very fragmentary decree of the deme Ikarion concerning the festival of Dionysos (IG I $\mathrm{I}^{3} 254$, ca. 440) and offers a detailed commentary of the text. He discusses the organization of the festival, the selection of choregoi, the dramatic performances, the chorus, the prizes, and the financial aspects of the festival (cf. IG I3 253).

144) J. wiseman, "Agonistic Festivals, Victors and Officials in the Time of Nero: An Inscribed Herm from the Gymnasium Area of Corinth", in E. GEBHARD and T.E. GREGORY (eds.), Bridge of the Untiring Sea. The Corinthian Isthmus from Prehistory to Late Antiquity (Hesperia Suppl. 48), Princeton, 2015, p. 193-246 [BE 2017, 214; SEG LXV 184]: Ed. pr. of a

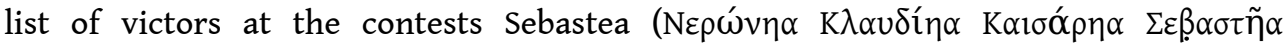

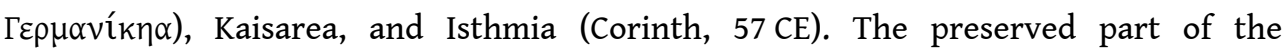
inscription, inscribed on a herm, provides the names of the agonothetes, the ten hellanodikai, the eisagogeus, and the xystarches, as well as the victors in the following disciplines: race ( $\delta \rho o ́ \mu \circ \zeta$, in the categories of boys, ageneioi, and men), torch-race (?), and stadion. W. points out that according to modern calculations concerning the dates on which these festivals were celebrated in the first cent. CE, one would not have expected all three of them to take place in $57 \mathrm{CE}$. However, the schedules of agonistic festivals were more flexible than modern reconstructions allow. It was in view of such irregularities that Hadrian attempted to reset the festivals' dates (SEG LVI 1359).

145) M. WÖRRLE, "Die ptolemäische Garnison auf der Burg von Limyra im Licht einer neuen Inschrift", in B. BECK-BRANDT, S. LADSTÄTTER, and B. YENER-MARKSTEINER (eds.), Turm und Tor. Siedlungsstrukturen in Lykien und benachbarten Kultlandschaften, Vienna, 2015, p. 291-303 [BE 2016, 465; SEG LXV 1469]: Ed. pr. of a decree of an association of basilistai, Ptolemaic mercenaries who participated in the ruler cult of the Ptolemies in Limyra (ca. 250-200). Only the last section of the decree survives. It stipulates the performance

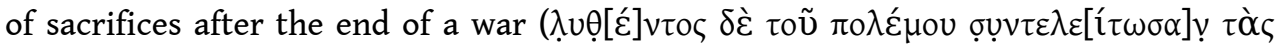

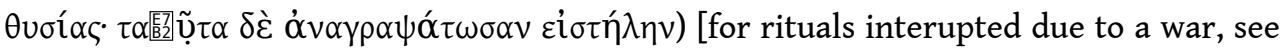
A. CHANiotis, War in the Hellenistic World: A Social and Cultural History, Malden, 2005, p. 162; C. HABICHT, "Versäumter Götterdienst", Historia 55 (2006), p. 153-166]. The decree was inscribed in the sanctuary of Artemis.

146) M. wöRRLE, "Epigraphische Forschungen zur Geschichte Lykiens XI: Gymnasiarchinnen und Gymnasiarchen in Limyra", Chiron 46 (2016), p. 403-451 [BE 
2017, 522]: Ed. pr. of honorific inscriptions for supervisors of the gymnasion in Limyra. One of the texts ( 3 , late 1 st cent. $\mathrm{CE}$ ) praises a gymnasiarchos who served in the year of the festival of the Lykian Koinon ( $\dot{\varepsilon} v \dot{\varepsilon} \theta v i k n ̣ n ~ \pi \alpha v \eta \gamma u ́ p \varepsilon l)$, providing olive oil to the

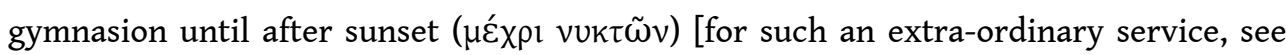
further examples in A. CHANIOTIS, "Nessun Dorma! Changing Nightlife in the Hellenistic and Roman East", in A. CHANIOTIS (ed.), La Nuit. Imaginaire et réalités nocturnes dans le monde gréco-romain (Entretiens Hardt 64), Geneva, 2018, p. 18f.]. Another gymnasiarchos

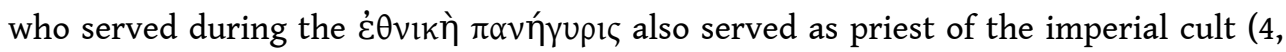
late 1st cent. CE). Other honorific inscriptions praise a priest $(4,1$ st cent. CE) and two priestesses (5, late 1st cent. CE; 6, ca. 150-200) of the emperors.

147) J.-B. Yon, "De Marisa à Byblos avec courrier de Séleucos IV. Quelques données sur Byblos hellénistique", in J. ALIQUOT and C. BONNET (eds.), La Phénicie hellénistique. Actes du colloque international de Toulouse (18-20 février 2013), Lyon, 2015, p. 89-105 [BE 2016, 527; SEG LXV 1640]: A letter of Seleukos III to his vizier Heliodoros (178 BCE) concerning the appointment of a supervisor of the sanctuaries in Koile Syria and Phoinike (178 BCE) was known from two copies in Marisa (SEG LVII 1838 and LXIV 1781; for a summary see $E B G R$ 2007, 36). Now Y. publishes a new fragmentary copy found at Byblos. Unfortunately, the new fragment only contains a text known from the other copies.

\section{AUTHOR}

\section{ANGELOS CHANIOTIS}

Institute for Advanced Study

Princeton

achaniotis@ias.edu 